\title{
Evaluation of Efficiency Activities in the Industrial Sector Undertaken in Response to Greenhouse Gas Emission Reduction Targets
}

\author{
Principal Investigator \\ Arpad Horvath \\ Department of Civil and Environmental Engineering \\ University of California - Berkeley \\ Prepared for the California Air Resources Board and \\ the California Environmental Protection Agency \\ Prepared by: \\ Lynn Price, Stephane de la Rue du Can, Hongyou Lu \\ Energy Analysis Department \\ Environmental Energy Technologies Division \\ Lawrence Berkeley National Laboratory
}

April 2010 


\section{Disclaimer}

The statements and conclusions in this Report are those of the contractor and not necessarily those of the California Air Resources Board. The mention of commercial products, their source, or their use in connection with material reported herein is not to be construed as actual or implied endorsement of such products. 


\section{Acknowledgments}

This work was supported by the California Air Resources Board through the U.S. Department of Energy under Contract No. DE-AC02-05CH11231. The authors of this report would like to thank Dorothy Shimer at the California Air Resources Board for her helpful guidance during this project.

We would also like to thank Mr. Emmanuel Martinez, Director of Environment in Société Générale, in charge of AERES, for explaining and providing documentation of the AERES program. We are also grateful to Ronald Vermeeren, Marco Kavelaars, Reiner Gerrits, Theo Leupen, and Michel de Zwart of SenterNovem who took time to describe the many features of the agreement programs in The Netherlands. Finally, we would like to thank Marie Pender of the UK Department for Environment, Food and Rural Affairs for her insights on the CCAs in the UK as well as for coordinating our interviews with association representatives. We are grateful to Bill Thompson of British Petroleum, Nick Sturgeon of the Chemicals Industries Association, Stephen Reeson of the Food and Drink Federation, David Pocklington of the British Cement Association, and Derek Boyd of the National Microelectronics Institute for explaining how the CCAs worked for their members and how their associations supported the CCAs.

This Report was submitted in fulfillment of Contract \#07-321 Evaluation of Efficiency Activities in the Industrial Sector Undertaken in Response to Greenhouse Gas Emission Reduction Targets by UC Berkeley and Lawrence Berkeley National Laboratory and under the sponsorship of the California Air Resources Board. Work was completed as of April 2010. 


\title{
Evaluation of Efficiency Activities in the Industrial Sector Undertaken in Response to Greenhouse Gas Emission Reduction Targets
}

\author{
Table of Contents
}

Abstract

Executive Summary ES-1

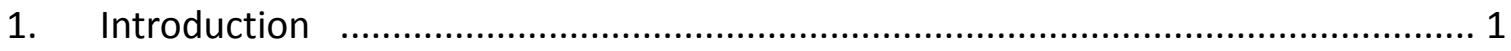

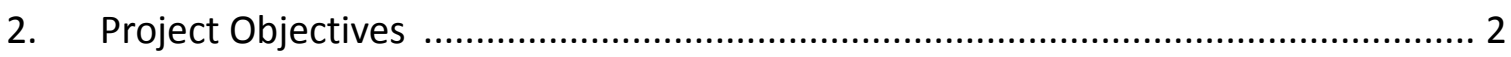

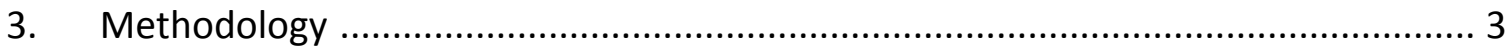

4. Characterization of the Industrial Sector in California................................. 4

5. Identification and Description of Industrial Sector Energy Efficiency and GHG Emission Reduction Programs in Other Countries Relevant to California ................ 8

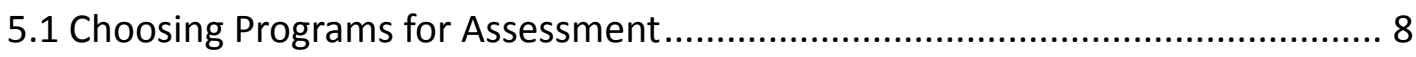

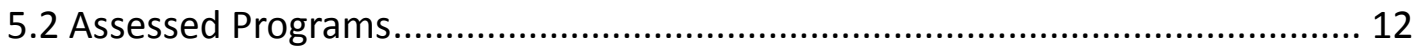

5.2.1 Ireland - Completely Voluntary ...................................................... 13

5.2.2 France - Program with Threat of Taxes or Regulation ....................... 22

5.2.3 Netherlands - Program with Threat of Taxes or Regulation............... 29

5.2.4 Denmark - Voluntary Agreement within GHG Tax Program............... 41

5.2.5 UK - Voluntary Agreement within GHG Tax Program ....................... 48

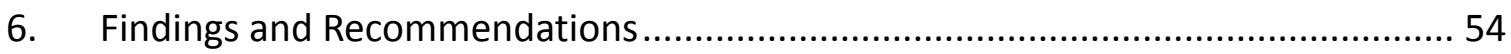

References

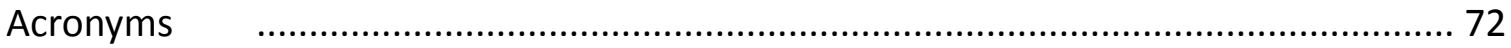

Appendix $\quad$ A. 


\section{List of Figures}

Figure 1. California Industrial Sector GHG Emissions in 2006 .......................................... 4

Figure 2. California Manufacturing Sector GHG Emissions in 2006 by Sub-Sector ................ 5

Figure 3. Manufacturing Energy Use by Sub-Sector Shares in California (2006)................... 7

Figure 4. Manufacturing Energy Use by Sub-Sector Shares for Selected Countries and

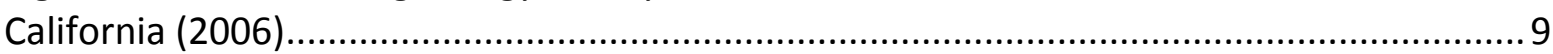

Figure 5. Growth of LIEN and EAP Membership (1995-2008) ......................................... 14

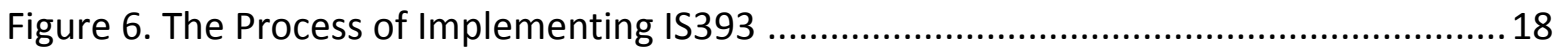

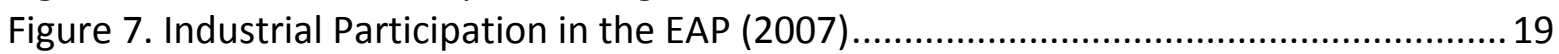

Figure 8. GHG Emissions from AERES Members and Overall Targets ( $\mathrm{MtCO}_{2}$ eq.) ................ 25

Figure 9. 2000 Target and Actual Energy Efficiency Improvement in Selected Industries in The Netherlands Compared to 1989 Baseline (\%) ............................................................... 33

Figure 10. Energy Efficiency Improvement Results of the Long-Term Agreements in The

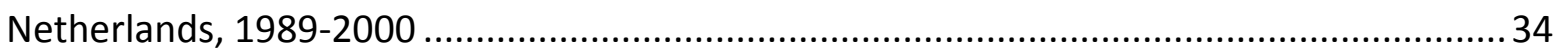

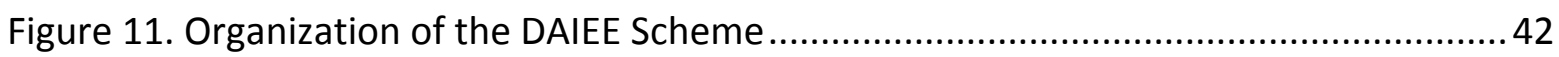

Figure 12. Five Steps for Energy Management ............................................................... 46 


\section{List of Tables}

Table 1. Overview of Industrial Sector Voluntary Agreement Schemes .............................. 11

Table 2. Overall Performance of LIEN Members, 2006-2008......................................... 15

Table 3. Performance of LIEN Members by Industrial Sub-Sector, 2007-2008........................16

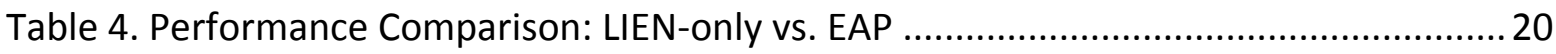

Table 5. AERES Membership and Commitment Emission Reduction Commitment by

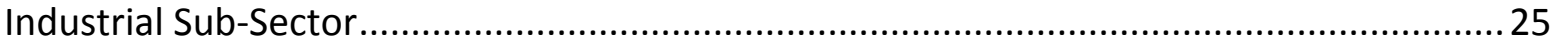

Table 6. GHG Emissions Targets and Realized Reductions by Industry Subsectors .............26

Table 7. 1996-2002 Danish $\mathrm{CO}_{2}$ Tax for Industry (in Euro per ton of $\mathrm{CO}_{2}$ ) ..........................41

Table 8. Energy, $\mathrm{SO}_{2}$, and $\mathrm{CO}_{2}$ Taxes for Different Energy Sources and Uses ...................... 42

Table 9. Number of Companies with Individual and Collective Agreements ........................ 44

Table 10. Total $\mathrm{CO}_{2}$ Emission Reduction Estimates in 2005 ............................................. 45

Table 11. Results of the UK Climate Change Agreements: Periods 1-4 .............................51 


\title{
Evaluation of Efficiency Activities in the Industrial Sector Undertaken in Response to Greenhouse Gas Emission Reduction Targets
}

\author{
Lynn Price, Stephane de la Rue du Can, Hongyou Lu \\ Energy Analysis Department \\ Environmental Energy Technologies Division \\ Lawrence Berkeley National Laboratory \\ Arpad Horvath \\ Department of Civil and Environmental Engineering \\ University of California-Berkeley
}

\begin{abstract}
The 2006 California Global Warming Solutions Act calls for reducing greenhouse gas (GHG) emissions to 1990 levels by 2020. Meeting this target will require action from all sectors of the California economy, including industry. The industrial sector consumes $25 \%$ of the energy used and emits $28 \%$ of the carbon dioxide $\left(\mathrm{CO}_{2}\right)$ produced in the state. Many countries around the world have national-level GHG reduction or energy-efficiency targets, and comprehensive programs focused on implementation of energy efficiency and GHG emissions mitigation measures in the industrial sector are essential for achieving their goals. A combination of targets and industry-focused supporting programs has led to significant investments in energy efficiency as well as reductions in GHG emissions within the industrial sectors in these countries. This project has identified program and policies that have effectively targeted the industrial sector in other countries to achieve real energy and $\mathrm{CO}_{2}$ savings. Programs in Ireland, France, The Netherlands, Denmark, and the UK were chosen for detailed review. Based on the international experience documented in this report, it is recommended that companies in California's industrial sector be engaged in a program to provide them with support to meet the requirements of AB32, The Global Warming Solution Act. As shown in this review, structured programs that engage industry, require members to evaluate their potential efficiency measures, plan how to meet efficiency or emissions reduction goals, and provide support in achieving the goals, can be quite effective at assisting companies to achieve energy efficiency levels beyond those that can be expected to be achieved autonomously.
\end{abstract}




\title{
Executive Summary
}

\section{Evaluation of Efficiency Activities in the Industrial Sector Undertaken in Response to Greenhouse Gas Emission Reduction Targets}

\author{
Lynn Price, Stephane de la Rue du Can, Hongyou Lu \\ Energy Analysis Department \\ Environmental Energy Technologies Division \\ Lawrence Berkeley National Laboratory \\ Arpad Horvath \\ Department of Civil and Environmental Engineering \\ University of California-Berkeley
}

\begin{abstract}
Background
In 2005, Governor Schwarzenegger announced greenhouse gas (GHG) emission reduction targets for California which call for reducing emissions to 2000 levels by 2010, to 1990 levels by 2020 , and to $80 \%$ below 1990 levels by 2050. The 2020 targets were included in the California Global Warming Solutions Act of 2006. The California Air Resources Board (ARB) has been given the tasks of adopting a statewide GHG limit for 2020 equivalent to 1990 emissions and to adopt rules, regulations, and market-based compliance mechanisms for achieving the maximum technologically feasible and cost-effective GHG emissions reductions.
\end{abstract}

Meeting the California Global Warming Solutions Act 2020 target will require action from all sectors of the California economy, including industry. The industrial sector consumes $25 \%$ of the energy used and emits $28 \%$ of the carbon dioxide $\left(\mathrm{CO}_{2}\right)$ produced in the state. Many countries around the world have national-level GHG reduction or energy-efficiency targets, and comprehensive programs focused on implementation of energy efficiency and GHG emissions mitigation measures in the industrial sector are essential for achieving their goals. A combination of targets and industry-focused supporting programs has led to significant investments in energy efficiency as well as reductions in GHG emissions within the industrial sectors in these countries.

\section{Methodology}

This project has identified program and policies that have effectively targeted the industrial sector in other countries to achieve real energy and $\mathrm{CO}_{2}$ savings. Increased energy efficiency and reduced GHG emissions can also lead to cost savings and improved competitiveness for industries, reduced emissions of other air pollutants and particulate matter, reduced water consumption, reduced production of waste and improved product quality. This report characterizes the industrial sector in California and describes GHG emission reduction voluntary agreement programs in five countries that have manufacturing sectors that are relatively similar to those found in California. 


\section{Result}

Voluntary agreement programs can be roughly divided into three broad categories: 1) programs that are completely voluntary, 2) programs that use the threat of future regulations or energy/GHG emissions taxes as a motivation for participation, and 3) programs that are implemented in conjunction with an existing energy/GHG emissions tax policy or with strict regulations. A variety of government-provided incentives as well as penalties are associated with these programs.

Voluntary agreements are "essentially a contract between the government and industry, or negotiated targets with commitments and time schedules on the part of all participating parties" (IEA, 1997). These agreements typically have a long-term outlook, covering a period of five to ten years, so that strategic energy-efficiency investments can be planned and implemented. A key element of voluntary agreements is that they focus the attention of all actors on energy efficiency or emission reduction goals.

Programs in Ireland, France, The Netherlands, Denmark, and the UK were chosen for detailed review. These programs fall into all three categories of voluntary agreements and have a number of interesting features. The report found that the surveyed countries that have national-level policies aimed at the reduction of GHG emissions all developed comprehensive programs to engage the industrial sector in identifying and implementing energy efficiency and GHG emission reduction technologies and measures. Even though the approaches differed by country and each country engaged a diverse range of industrial subsectors, the results of most of these programs were impressive. Some programs realized energy savings in the range of $3 \%$ to $8 \%$ per year and most companies engaged in the programs either realized or surpassed what were initially perceived to be ambitious savings targets.

The five agreement programs reviewed in this report represent very different overall approaches. Four of the five programs were established by the government in support of overall energy efficiency or GHG emissions reduction goals. The fifth, the AERES program in France, was an industry-driven program that was established with the motivation to proactively avoid government-imposed carbon taxes. The Dutch LTA programs also provided industry with the reassurance that if they participated in the agreements they would be not be subjected to additional regulatory requirements, including energy or $\mathrm{CO}_{2}$ taxes. Participants in both the Dutch LTAs and the UK CCAs were given special treatment regarding environmental requirements typically imposed on large industries. In the Netherlands, companies were given an expedited environmental permitting process while in the UK compliance with environmental permits was granted automatically if the CCA targets were met by a company.

\section{Conclusion}

Despite the programmatic differences, some key elements in most of the programs appear to have provided industry with the structure and support needed to accomplish, and often exceed, the programmatic energy-saving or emissions-reduction goals. These key elements include required company commitments to sign energy-saving or emissions reduction target agreements, to undertake energy audits, develop energy action plans, and implement energy management programs; monitoring, reporting and verification requirements; and 
supporting government programs that provided participating companies with information on energy-efficient and GHG mitigation technologies and measures, provided resources and tools, established information-sharing platforms, provided energy audits, and provided financial incentives and support.

Despite initial concerns voiced prior to the establishment of these programs, assessments show that they often were responsible for increasing the adoption of energy-efficiency and GHG mitigation technologies beyond what would have been adopted without the programs.

Based on the international experience documented in this report, it is recommended that companies in California's industrial sector be engaged in a program to provide them with support to meet the requirements of AB32, The Global Warming Solution Act. As shown in this review, structured programs that engage industry, require members to evaluate their potential efficiency measures, plan how to meet efficiency or emissions reduction goals, and provide support in achieving the goals, can be quite effective at assisting companies to achieve energy efficiency levels beyond those that can be expected to be achieved autonomously. Thus, a program that is carefully designed with clear guidelines, specific monitoring, reporting, and verification protocols, and especially robust supporting programs to assist California's manufacturers to identify and implement energy-efficiency and GHG emissions mitigations technologies and measures could be designed to compliment AB32 and increase the energy-efficiency and competitiveness of California's industries. 


\title{
Evaluation of Energy Efficiency Activities in the Industrial Sector Undertaken in Response to Greenhouse Gas Emission Reduction Targets
}

\author{
Lynn Price, Stephane de la Rue du Can, Hongyou Lu \\ Energy Analysis Department \\ Environmental Energy Technologies Division \\ Lawrence Berkeley National Laboratory \\ Arpad Horvath \\ Department of Civil and Environmental Engineering \\ University of California-Berkeley
}

\section{Introduction}

In 2005, Governor Schwarzenegger announced greenhouse gas (GHG) emission reduction targets for California which call for reducing emissions to 2000 levels by 2010, to 1990 levels by 2020, and to $80 \%$ below 1990 levels by 2050 . The 2020 targets were included in the California Global Warming Solutions Act of 2006. The California Air Resources Board (ARB) has been given the tasks of adopting a statewide GHG limit for 2020 equivalent to 1990 emissions and to adopt rules, regulations, and market-based compliance mechanisms for achieving the maximum technologically feasible and costeffective GHG emissions reductions.

Meeting the California Global Warming Solutions Act 2020 target will require action from all sectors of the California economy, including industry. The industrial sector consumes $25 \%$ of the energy used and emits $28 \%$ of the carbon dioxide $\left(\mathrm{CO}_{2}\right)$ produced in the state. Many countries around the world have national-level GHG reduction or energy-efficiency targets, and comprehensive programs focused on implementation of energy efficiency and GHG emissions mitigation measures in the industrial sector are essential for achieving their goals. A combination of targets and industry-focused supporting programs has led to significant investments in energy efficiency as well as reductions in GHG emissions within the industrial sectors in these countries.

This project has identified program and policies that have effectively targeted the industrial sector in other countries to achieve real energy and $\mathrm{CO}_{2}$ savings. Increased energy efficiency and reduced GHG emissions can also lead to cost savings and improved competitiveness for industries, reduced emissions of other air pollutants and particulate matter, reduced water consumption, reduced production of waste and improved product quality. This report concludes with recommendations for specific industrial sector program designs that could be implemented in California in support of the 2020 GHG emissions reduction target outlined in the 2006 Global Warming Solutions Act. 


\section{Project Objectives}

In order to provide a summary of lessons learned and make recommendations for specific industrial sector program designs that could be implemented in California in support of the 2020 GHG emissions reduction target outlined in the 2006 Global Warming Solutions Act, the objectives of this research were as follows: 1 ) to characterize the industrial sector in California, 2) to identify and describe GHG emission reduction programs in other countries relevant to California, and 3) to identify and describe specific GHG emission reduction technologies and measures that were undertaken in response to GHG emission reduction target-setting programs in other countries.

\section{Objective 1: Characterizing the Industrial Sector in California}

California's industrial sector is diverse and encompasses a number of energy-intensive industries such as petroleum refining and cement making as well as many smaller sectors such as textiles, equipment manufacturing, and furniture making. The most recent detailed data on energy consumption by industrial sub-sectors for California is provided for 2006 by the California Energy Balance (CALEB). California's industrial subsectors are ranked in terms of both their energy use and $\mathrm{CO}_{2}$ emissions in order to identify key California industrial sub-sectors.

Objective 2: Identifying and Describing GHG Emission Reduction Target-Setting Programs in Other Countries Relevant to California

Numerous GHG emission reduction programs that focus on the industrial sector exist in other countries. These programs are identified and described and five national-level programs that address industrial sectors important in California are assessed in further detail in order to understand lessons learned regarding program design and delivery as well as applicable elements for possible adoption in California. For each program identified, the general program design is described along with an assessment of the level of industry participation and the realized energy savings. Program design elements such as information dissemination related to efficiency options, facility auditing, benchmarking, facility-level target-setting, development of implementation plans, energy management programs, monitoring of progress towards targets and financial incentives are described.

Objective 3: Identifying and Describing Specific GHG Emission Reduction Technologies and Measures Undertaken in Industrial Target-Setting Programs in Other Countries Relevant to California

To the extent possible, specific actions taken by industrial firms in response to targetsetting agreements in other countries are identified and described in order to more clearly demonstrate how such industries achieve their stated energy efficiency or GHG emissions mitigation goals. 


\section{Methodology}

This project relied upon literature reviews, interviews, and data collection and analysis in order to complete the evaluation of California's industrial sector as well as the energy efficiency activities undertaken in other countries in response to GHG emission reduction targets.

Literature review was used to identify energy efficiency or GHG emission reduction programs in other countries that focus on industries relevant to California. Literature reviews and interviews were used to understand the key program design elements as well as to identify the specific GHG emission reduction technologies and measures that were undertaken by facilities participating in national level energy efficiency and GHG emissions reduction programs.

Data were collected and analyzed to characterize the industrial sector in California in order to determine which industrial sub-sectors are the largest energy consumers and $\mathrm{CO}_{2}$ emitters. When possible, data were also collected and analyzed to understand the energy savings and emissions reductions associated with the national level energy efficiency and GHG emissions reduction programs analyzed in this project.

Data collected for the first task of this project include energy consumption data for California industrial sub-sectors, electricity emissions factors for California in-state and imported electricity, and conversion factors for calculating $\mathrm{CO}_{2}$ emissions from fuels consumed in California.

The second task of this project involved collecting information via websites of the various program, reports, journal articles, meetings, and telephone calls.

The third task of this project involved collecting information on the variety of technologies and measures implemented by industrial sub-sectors that participated in the studied programs. Due to lack of publicly reported information, it was not possible to collect data on the implementation cost of each specific energy efficiency or GHG mitigation measure and the estimated annual energy savings or GHG emissions reduction achieved by each specific energy efficiency or GHG mitigation measure.

All of the sources are fully documented in the reference section of this report. 


\section{Characterization of the Industrial Sector in California}

According to the last California ARB GHG inventory, the industrial sector represents the second largest source of emissions in California after the transportation sector (CARB, 2009a). In 2006, activity in the industrial sector resulted in emissions of about 102.6 $\mathrm{MtCO}_{2}$ eq, representing $21 \%$ of all GHGs emitted in California. When indirect emissions related to the use of electricity are accounted in the end use sectors, total GHG emissions for the industrial sector increase to $123.9 \mathrm{MtCO}_{2}$ eq. representing $25 \%$ of all GHGs emitted in the State.

Figure 1 shows the breakdown of GHG emissions in the industrial sector by major industry subsectors and by major gas emitted, including indirect $\mathrm{CO}_{2}$ emissions from electricity use ${ }^{1}$ and indirect emissions from production of useful thermal output in combined heat and power (CHP) plants. ${ }^{2}$

Figure 1. California Industrial Sector GHG Emissions in 2006

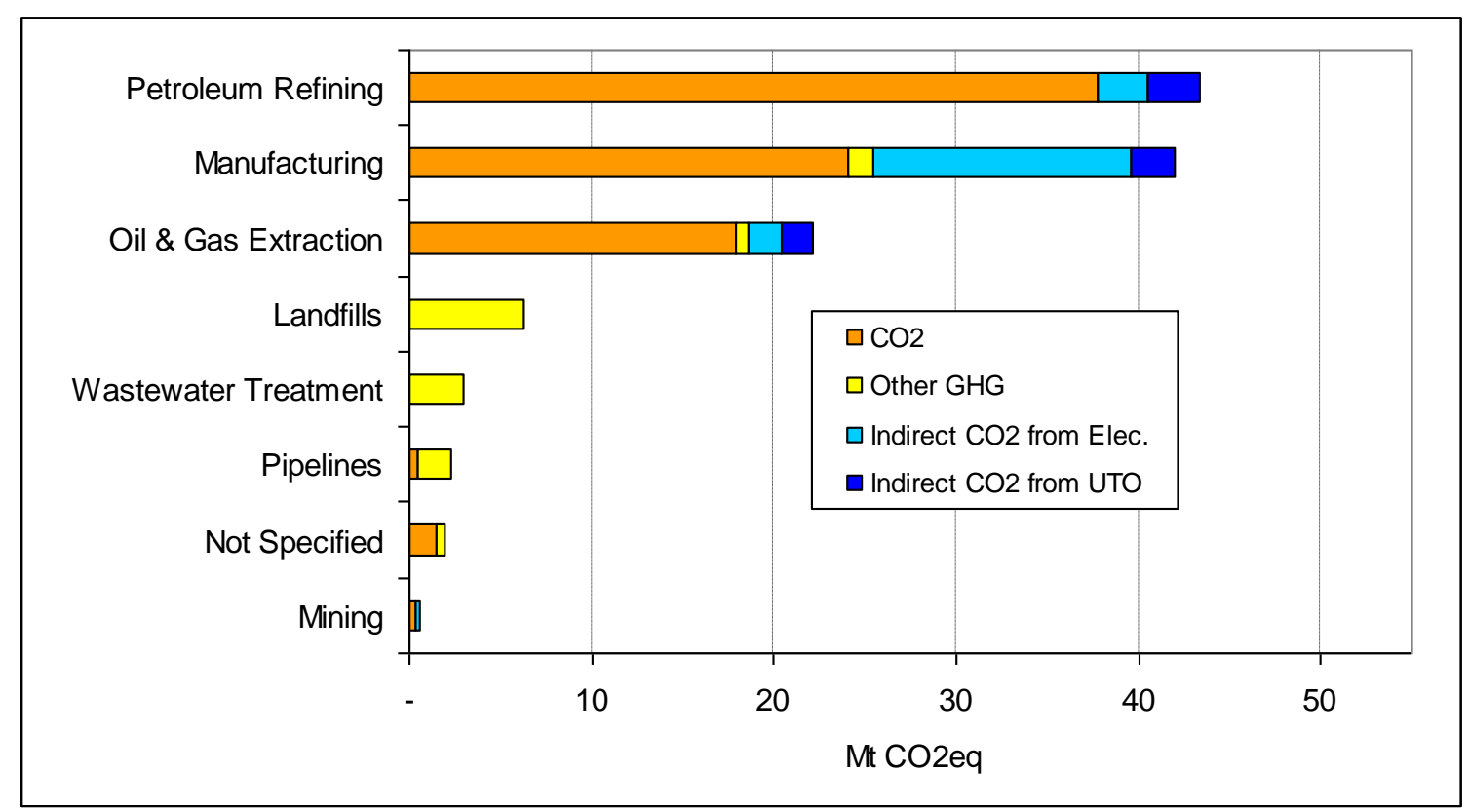

UTO: Useful Thermal Output ${ }^{2}$.

Not Specified: emissions from the "not specified" sub-sector include fuels used across all other subsectors (except cement) but for which no detailed statistics exist to break them out by sub-sectors.

Source: CARB, 2009a; LBNL own estimates

\footnotetext{
${ }^{1}$ Indirect $\mathrm{CO}_{2}$ emissions from electricity use were calculated by dividing total emissions from electricity generation (including imports) (CARB, 2009a) with total sales of electricity (LBNL, forthcoming). The resulting carbon electricity factor $\left(0.38 \mathrm{tCO}_{2} / \mathrm{MWh}\right)$ was then applied to electricity sales to each end use sectors (LBNL, forthcoming).

${ }^{2}$ Indirect $\mathrm{CO}_{2}$ emissions from useful thermal output (UTO) CHP production were calculated by compiling inputs to CHP plants from the EIA power sector annual database (EIA, 2009) and converting the data in $\mathrm{CO}_{2}$ emissions by using $\mathrm{CO}_{2}$ emission factors from CARB (CARB, 2009a).
} 
Figure 2 provides a further breakdown of the California manufacturing sector GHG emissions in 2006 by sub-sectors (CARB, 2009a; LBNL own estimates).

Figure 3 provides the manufacturing sector primary energy use in 2006 by sub-sectors (LBNL, forthcoming). In 2006, California's manufacturing sector consumed 1,333 TJ $(1,264 \mathrm{TBtu}) .^{3}$ The food, non-metallic minerals (e.g. cement), chemicals, and machinery production sub-sectors, along with the catch-all non-specified sub-sector, are the dominant industries in California.

Figure 2. California Manufacturing Sector GHG Emissions in 2006 by Sub-Sector

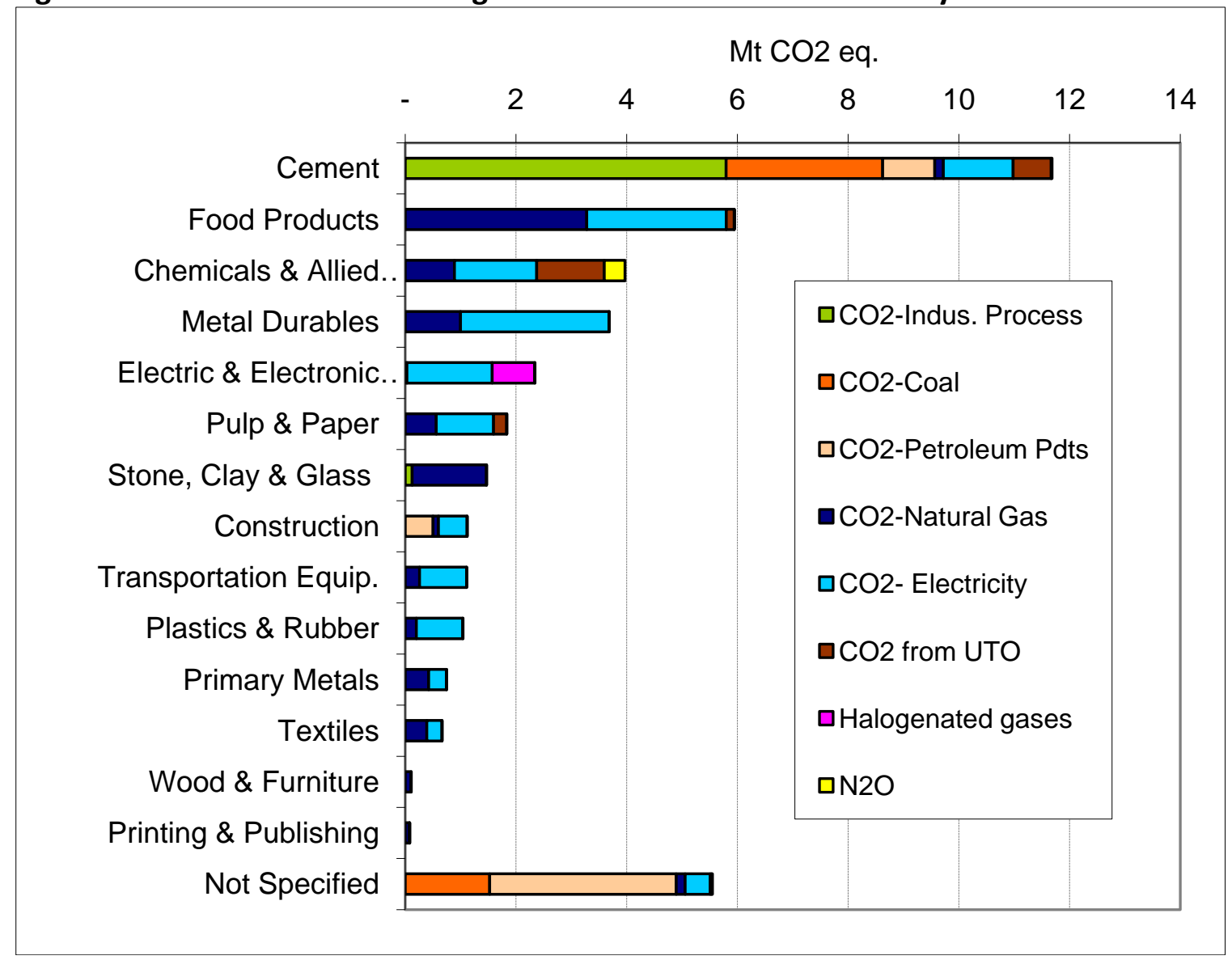

Source: CARB, 2009a; LBNL own estimates

Not Specified: emissions from the "not specified" sub-sector called not specified include fuels used across all other sub-sectors (except cement) but for which no detailed statistics exist to break them out by subsectors.

Source: CARB, 2009a; LBNL own estimates

\footnotetext{
${ }^{3}$ Data compiled from upcoming LBNL revision to the California Energy Balance (LBNL, forthcoming).
} 
When the manufacturing GHG emissions shown in Figure 2 are compared with the manufacturing energy consumption shown in Figure 3, the shares of several sub-sectors differ due to non-energy-related emissions. For example, the chemical and petrochemical sectors use large quantities of fossil fuels as feedstocks that are not emitted, but rather stored in the manufactured product. This is also the case of the cement industry (within the non-metallic mineral sub-sector), which is the largest source of GHG emissions in the manufacturing sector, representing $32 \%$ of all emissions. Cement production is not only a source of combustion-related $\mathrm{CO}_{2}$ emissions due to the use of on coal and petroleum coke but also because of the process-related emissions resulting from the release of $\mathrm{CO}_{2}$ during the calcination of limestone.

The next largest source of emissions is the food industry which uses significant quantities of natural gas for steam and electricity for refrigeration and motors. This sector represents $14 \%$ of the manufacturing industry emissions. This is followed by chemicals and the metal durables manufacturing that have similar total GHG emissions, each representing $10 \%$. The electric \& electronic equipment sector is the principal source of halogenated gases. About $16 \%$ of manufacturing GHG emissions are not associated with any specific industries and are in the category "not specified". These are mostly emissions from petroleum products and some coal whose final use is not accounted at a more detailed level.

California's industrial sector consumed 1,333 TJ (1,264 TBtu) in 2006. The food, nonmetallic minerals (e.g. cement), chemicals, and machinery production sub-sectors, along with the catch-all non-specified sub-sector, are the dominant industries in California (see Figure 3).

The California Energy Balance (CALEB) provides the most complete detailed data on energy consumption by industrial sub-sectors. However, the last edition of CALEB was published in 2005 and includes data only up to 2002. In order to provide a more recent overview of industrial energy used in California, data on individual fuels for later years (typically up to 2006) were gathered and updated in CALEB database.

Several sources of data were used. Data on natural gas and electricity by sub-sectors were collected from the California Energy Commission (CEC) (CEC, 2009a). Fuels used in the refinery sector were also collected from the CEC (CEC, 2009b). The Energy Information Administration (EIA) provided data on fuel oil (US EIA, 2009a), petrochemical fuel use (US EIA, 2009b) and fuel used by CHP plants (EIA, 2009c). Finally, energy used by cement plants was provided by the U.S. Geological Survey (USGS) (USGS, 2009). This work was undertaken in collaboration with efforts being funded by the California Energy Commission (CALEB Phase III project) which will provide an update of CALEB by the fall of 2010 (LBNL, forthcoming). 
Figure 3. Manufacturing Energy Use by Sub-Sector Shares in California (2006)

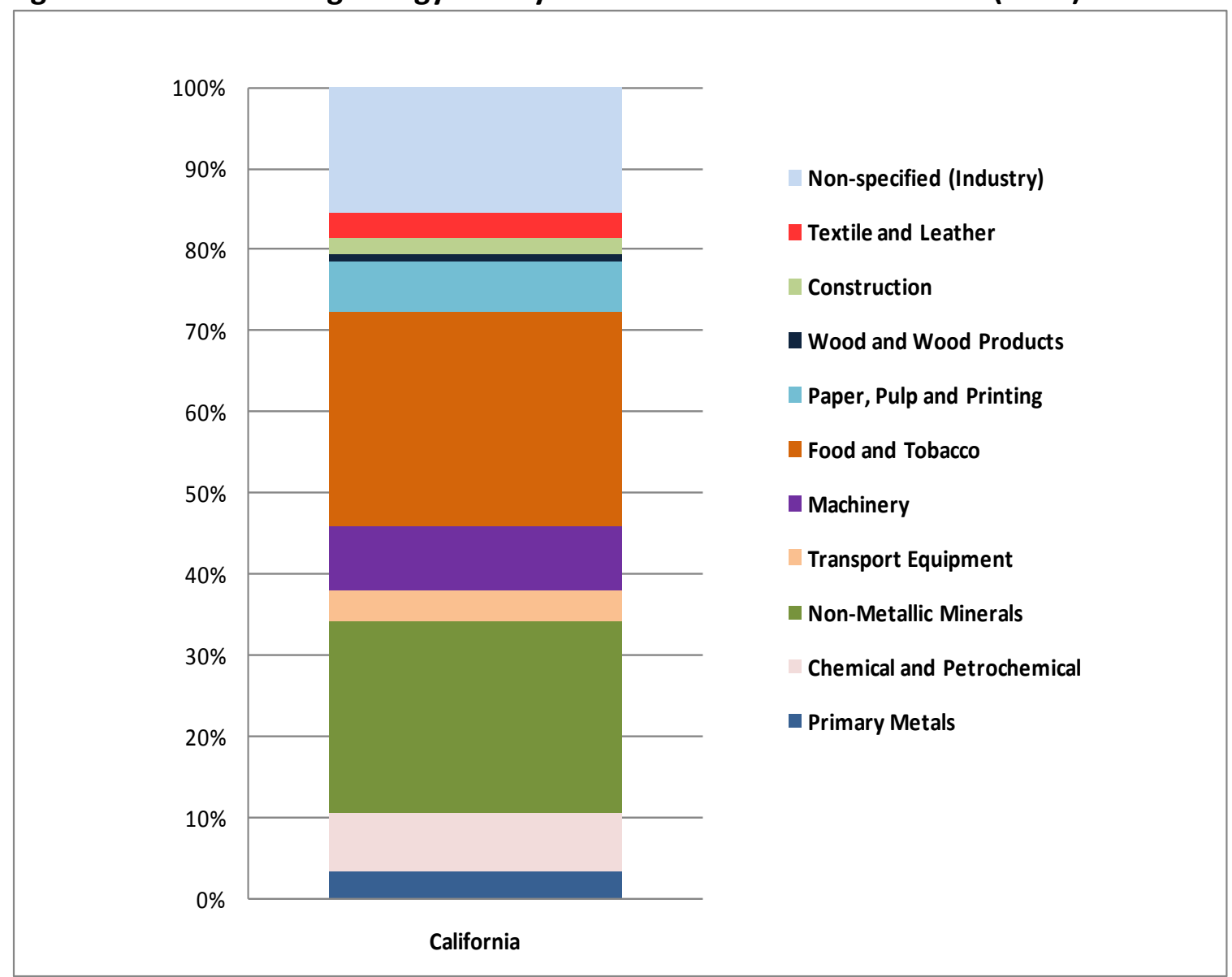

Source: LBNL, forthcoming 


\section{Identification and Description of Industrial Sector Energy Efficiency and GHG Emission Reduction Programs in Other Countries Relevant to California}

\subsection{Choosing Programs For Assessment}

In order to choose three to five national-level industrial sector energy efficiency and GHG emission reduction programs to assess, information was gathered on the composition of the manufacturing sectors ${ }^{4}$ of a selected number of countries that have target-setting programs in order to compare them with the structure of California's manufacturing sector. In addition, basic information was gathered on 16 voluntary agreement programs in 13 countries in order to identify a variety of programs to review on a more detailed basis.

Figure 4 compares the sub-sector shares of California's manufacturing sector to those found in the 13 countries with voluntary agreement programs that were initially reviewed in this study. The data for the 13 countries is derived from the International Energy Agency's Energy Balances (IEA, 2009). The information on California is derived from LBNL's forthcoming update to the California Energy Balance (LBNL, forthcoming).

The comparison shows that Denmark's manufacturing sector is the most similar to that in California. Both have large food and non-metallic minerals sectors.

Countries with manufacturing sectors that are significantly different from California's include Australia which has notably more primary metals manufacturing, Canada and Sweden which have more paper, pulp, and printing industries, and New Zealand which has more wood and wood products manufacturing. The remaining countries are more or less similar to California in the structure of the manufacturing sector.

\footnotetext{
${ }^{4}$ Petroleum refining, a major source of GHG emissions in California, is not included in the category of "manufacturing" but rather is a transformation industry. As such, it is not included in IEA statistics on manufacturing end-use energy consumption and emissions.
} 
Figure 4. Manufacturing Energy Use by Sub-Sector Shares for Selected Countries and California (2006)

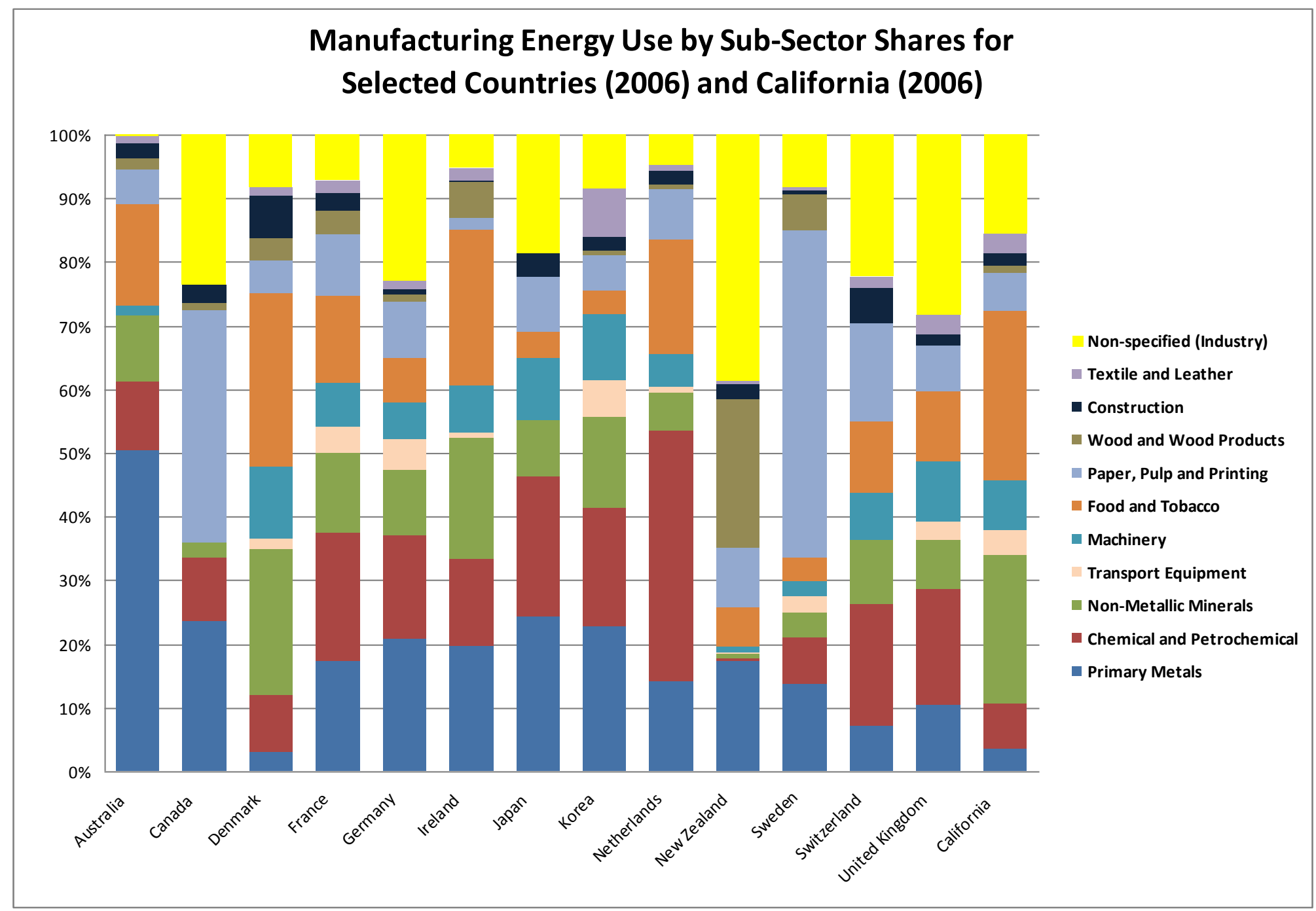

Sources: IEA, 2009; LBNL, forthcoming. 
Voluntary agreement programs can be roughly divided into three broad categories: 1 ) programs that are completely voluntary, 2) programs that use the threat of future regulations or energy/GHG emissions taxes as a motivation for participation, and 3) programs that are implemented in conjunction with an existing energy/GHG emissions tax policy or with strict regulations. A variety of government-provided incentives as well as penalties are associated with these programs (Price, 2005).

Voluntary agreements are "essentially a contract between the government and industry, or negotiated targets with commitments and time schedules on the part of all participating parties" (IEA, 1997). These agreements typically have a long-term outlook, covering a period of five to ten years, so that strategic energy-efficiency investments can be planned and implemented. A key element of voluntary agreements is that they focus the attention of all actors on energy efficiency or emission reduction goals (Price, 2005).

Table 1 provides an overview of key characteristics of 16 voluntary agreement programs in 13 countries. Completely voluntary programs have been implemented in 5 countries: Australia, Canada, Ireland, South Korea, and New Zealand. The Canadian program includes the largest number of companies $(5,000)$, but is also the least constraining. It provides companies with a network of expertise on energy-efficiency measures and financial incentives without setting any targets. The other programs in the completely voluntary category have similar features but focus on large energy users. Some also require members to undertake an energy audit and set energy or emission reduction targets.

Programs with threatened regulations or taxes are found in four countries: France, Germany, Japan, and The Netherlands. In France and Germany, companies undertook the initiative to established programs that set emissions reduction targets, while the government is present only as an observer. Japan has a similar program but with the government playing a more active role in setting the overall emission reduction target. The Netherlands has the most extensive experience with voluntary agreement programs, with their first program starting in 1989.

Finally, voluntary agreements within energy or GHG tax programs are found in Australia, Denmark, Sweden, Switzerland and the UK. Commonly within these programs, companies that sign agreements can get relief or exemption from the country's energy or carbon tax. 
Table 1. Overview of Industrial Sector Voluntary Agreement Schemes

\begin{tabular}{|c|c|c|c|c|c|c|c|c|c|c|c|c|c|c|c|c|c|c|}
\hline \multirow[b]{2}{*}{ Country } & \multirow[b]{2}{*}{ VA Scheme } & \multirow[b]{2}{*}{$\begin{array}{l}\text { Program } \\
\text { Years }\end{array}$} & \multicolumn{3}{|c|}{ Participation } & \multicolumn{10}{|c|}{ Incentives } & \multicolumn{3}{|c|}{ Penalties } \\
\hline & & & 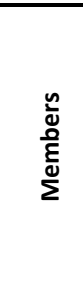 & 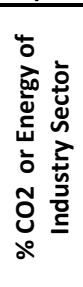 & 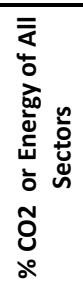 & 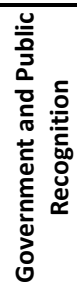 & 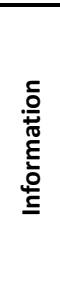 & 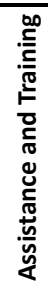 & 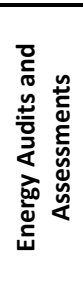 & 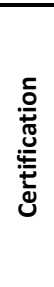 & 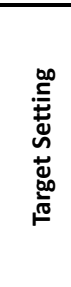 & 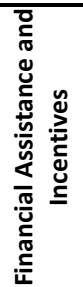 & 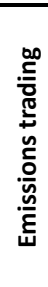 & 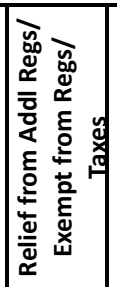 & 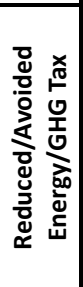 & 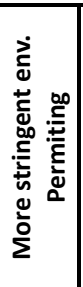 & 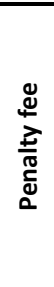 & 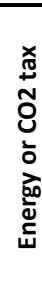 \\
\hline \multicolumn{19}{|c|}{ Completely Voluntary } \\
\hline Australia & Greenhouse Challenge Plus (GCP) & 2005-present & 750 & $50 \%$ & & $\mathrm{x}$ & $\mathrm{x}$ & $\mathrm{x}$ & $\mathrm{x}$ & & & & & & & & & \\
\hline Canada & $\begin{array}{l}\text { Industry Program for Energy } \\
\text { Conservation }\end{array}$ & 2005-present & 5,000 & $98 \%$ & & $x$ & $\mathrm{x}$ & $x$ & & & & $\mathrm{x}$ & & & & & & \\
\hline Ireland & $\begin{array}{llll}\text { Large } & \text { Industry } & \text { Energy } & \text { Network } \\
\text { (LIEN) } & & & \\
\end{array}$ & 1995-present & 122 & $>60 \%$ & $14 \%$ & $x$ & $x$ & $x$ & $x$ & & $x$ & & & & & & & \\
\hline Ireland & Energy Agreements Programme & 2006-present & 80 & & & & & $x$ & & $x$ & & $x$ & & & & & & \\
\hline South Korea & $\begin{array}{l}\text { VA System For Energy Conservation } \\
\& \text { Reduction of GHG Emissions }\end{array}$ & 1998-present & 1,383 & & & $\mathrm{x}$ & $x$ & $\mathrm{x}$ & & & $x$ & $x$ & & & & & & \\
\hline New Zealand & Emprove & 2002-present & 300 & & & $x$ & $x$ & $x$ & $x$ & & & $x$ & & & & & & \\
\hline \multicolumn{19}{|c|}{ Threatened Regulations or Taxes } \\
\hline France & AERES Negotiated Agreements & 2002-2007 & 33 & $50 \%$ & $18 \%$ & $x$ & & & & & $x$ & & $x$ & & & & $x$ & \\
\hline Germany & Agreement on Climate Protection & $2000-2012$ & 4,400 & $70 \%$ & & $x$ & & & & & $\mathrm{x}$ & & & & & & & \\
\hline Japan & $\begin{array}{l}\text { Keidanren Voluntary Action Plan on } \\
\text { the Environment }\end{array}$ & 1997-present & 131 & $82 \%$ & $42 \%$ & $x$ & & & & & & & $x$ & & & & & \\
\hline Netherlands & $\begin{array}{l}\text { Long Term Agreements on Industrial } \\
\text { Energy Efficiency }\end{array}$ & $\begin{array}{l}1989-2000 \\
2000-2008 \\
\end{array}$ & 1,250 & $90 \%$ & & $x$ & $x$ & $x$ & $x$ & & & $x$ & & $x$ & & $x$ & & \\
\hline Netherlands & Benchmarking Covenants & 2001-2008 & & & & $x$ & $x$ & & & & & $\mathrm{x}$ & & $\mathrm{x}$ & & $\mathrm{x}$ & & \\
\hline \multicolumn{19}{|c|}{ Energy/GHG Taxes or Regulations } \\
\hline Australia & Energy Efficiency Opportunities & 2006-present & 250 & & $45 \%$ & $x$ & $x$ & $x$ & & & & & & & & & & \\
\hline Denmark & $\begin{array}{l}\text { Agreements on Industrial Energy } \\
\text { Efficiency }\end{array}$ & 1993-present & 143 & $45 \%$ & & $\mathrm{x}$ & $\mathrm{x}$ & $\mathrm{x}$ & $\mathrm{x}$ & $x$ & & $\mathrm{x}$ & & & $x$ & & & $\mathrm{x}$ \\
\hline Sweden & $\begin{array}{l}\text { Program for Improving Energy } \\
\text { Efficiency in Energy-Intensive } \\
\text { Industries }\end{array}$ & $2005-2010$ & 117 & & & $\mathrm{x}$ & & $\mathrm{x}$ & $\mathrm{x}$ & $\mathrm{x}$ & & & & & $\mathrm{x}$ & & & $\mathrm{x}$ \\
\hline Switzerland & CO2 Law Voluntary Measures & 2002-2012 & 1,800 & $40 \%$ & & $x$ & & & & & $x$ & & $x$ & & $x$ & & & $x$ \\
\hline UK & Climate Change Agreements & 2001-2013 & 5,000 & $90 \%$ & & $\mathrm{x}$ & $x$ & $x$ & $x$ & & & $x$ & $x$ & & $x$ & & & $x$ \\
\hline
\end{tabular}




\subsection{Assessed Programs}

During the first phase of this project, a brief review of the voluntary agreement programs in each country was undertaken in order to identify potential programs for further evaluation. This review is documented in the appendix to this report. This review was provided to the California ARB and recommendations were made regarding which programs to examine in more detail for this report. Programs were chosen in all three voluntary agreement categories in order to better understand the differences in program structure and components. Programs were also chosen based on the availability of program documentation and assessments.

For programs in the "Completely Voluntary" category, LBNL recommended focusing on the Large Energy Industry Network and Energy Agreement Program in Ireland because of the availability of information on these efforts and the fact that the first program, which began in 1995, has nearly 15 years of documented results. With a few important exceptions, Ireland's industrial sector energy use is also relatively similar to that in California.

For the "Threatened Regulations or Taxes" category, LBNL recommended reviewing both the industry-initiated program in France and the Long-Term Agreements in The Netherlands. France was chosen to represent a case study where industry played a leading role in formation of the agreement scheme. Moreover, the sectoral breakdown of energy use in the French industry is similar to the California industry and the economies are of a similar size. The Long-Term Agreement program in The Netherlands has extensive documentation and assessments were made following its completion in 2000.

For agreement programs that are associated with national-level energy or GHG tax programs, LBNL recommended reviewing the programs in Denmark and the UK. Denmark was selected because the industrial sub-sector energy share breakdown of Denmark is very similar to that of California. UK Climate Change Agreements were chosen because they represent a relatively recently established program that is associated with the imposition of an energy or $\mathrm{CO}_{2}$ tax.

Thus, this section provides a more detailed review of the industrial target-setting programs in five countries: Ireland, France, The Netherlands, Denmark, and the UK. 


\subsubsection{Ireland - Completely Voluntary}

Ireland has two complimentary programs that are evaluated here: the Large Industrial Energy Network and the Energy Agreement Program.

\section{Large Industry Energy Network (LIEN)}

The Large Industry Energy Network (LIEN) grew from a pilot project in 1993-1994 which involved ten major companies from different sectors (SEI, 2009a). The LIEN was formally established in 1995, and became one of the longest programs to pursue best practice in energy management for large industries.

On May 8, 2009, the Irish government published the National Energy Efficiency Action Plan 2009-2020 (NEEAP), which is Ireland's first comprehensive national energy efficiency policy (DCENR, 2009b). The NEEAP outlined an "ambitious but achievable" target of realizing $20 \%$ energy efficiency gain by 2020 . As a successful model of government and business working together to address the energy issues, the LIEN will continue to play an important role in realizing this plan.

\section{Program Design}

$\underline{\text { Structure }}$

Sustainable Energy Ireland (SEI), Ireland's national energy agency established by the Sustainable Energy Act in 2002, is the central agency in charge of the LIEN activities. The work of SEI is funded by the Irish Government through the National Development Plan with programs partially financed by the European Union (SEI, 2007; SEI, 2009b).

\section{Commitments and Benefits}

Although the LIEN is a voluntary program, companies that participate in the program make commitments to develop a management program for energy use, set and review energy targets, undertake an annual energy audit, and produce annual statement of energy accounts. In addition, companies also agree to monitor the process as well as publicize results (SEI \& LIEN, 2008).

Benefits for the LIEN members include direct benefits from savings of energy costs and reducing carbon emissions, as well as other indirect benefits, such as continuous energyefficiency improvement from an established energy management system, improved product quality from stringent standards, better domestic and international public image, and fewer difficulties for companies to meet future requirements on energy saving and emission reduction.

A series of supportive programs are established each year by the LIEN, which provides the members a platform to learn from experts and other specialists, to have access to information, seminars and workshops, and to facilitate members in taking actions on energy efficiency. A list of activities organized by LIEN in 2007 include the SEI Sustainable Energy Awards; a workshop on Combined Heat and Power; a heating, ventilation, and cooling (HVAC) special working group to indentify energy-efficient opportunities; an 
Energy Awareness Workshop to demonstrate tools and resources for implementing or improving energy recognition at LIEN members' facilities; and other workshops on issues related to plastics processing, energy markets, renewable energy for industry, and staff awareness campaigns (SEI \& LIEN, 2008).

\section{Compliance}

Since LIEN is a voluntary program, there are no compliance mechanisms associated with participation. Industries are free to join or withdraw from LIEN as they wish. As members of LIEN, there are no penalties for non-compliance with LIEN goals.

\section{Industry Participation}

The LIEN is targeted at large companies that have an annual energy costs over $€ 1$ million $(\sim 1.5 \text { million USD) })^{5}$ and/or those who are a part of the Energy Agreement Programme (see description below). As of 2008, 122 of Ireland's largest industrial companies participate in LIEN, ${ }^{6}$ accounting for over $60 \%$ of total industrial energy consumption and $14 \%$ of total primary energy consumption in Ireland (Gudbjerg, 2009).

\section{Figure 5. Growth of LIEN and EAP Membership (1995-2008)}

\section{Membership}

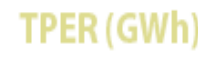

140

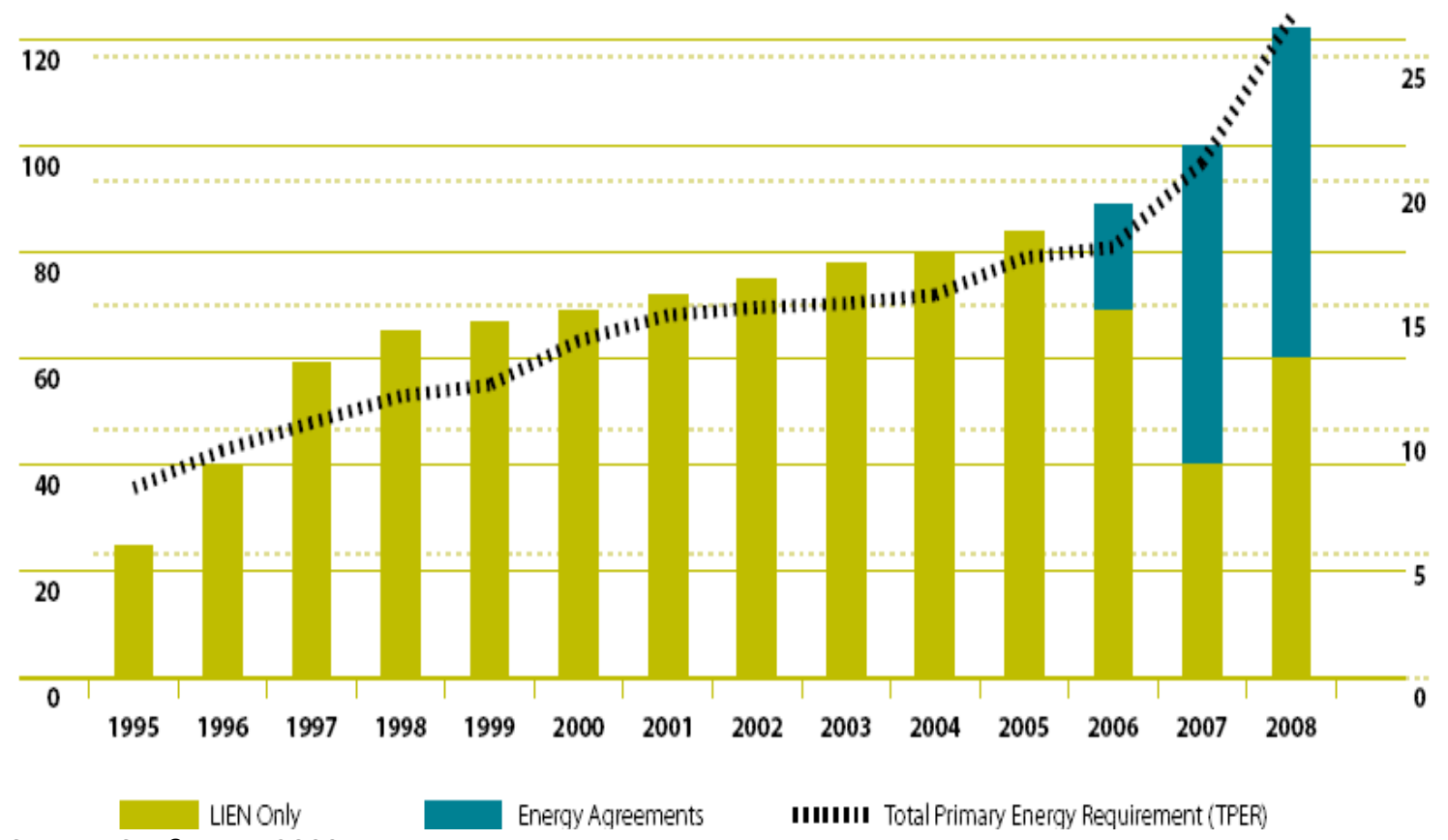

Source: SEI \& LIEN, 2009.

The LIEN membership includes the power generation sector and all of the qualified companies in Ireland's cement sector participate in LIEN. Overall, 55\% of the LIEN companies are from the pharmaceutical/chemical and the food/drink sectors, which

\footnotetext{
${ }^{5} 2008$ exchange rate of $0.68 €$ per US\$ (OECD, 2009).

${ }^{6}$ In 2008, 27 new members joined the LIEN while 8 members left, due to either closure or restructure (SEI \& LIEN, 2009).
} 
have 31 and 29 companies, respectively. Healthcare and electronics companies account for $10 \%$ of LIEN membership each. On average, LIEN members spend around €8 million ( $\$ 11.8$ million USD) per year on energy. The combined energy expenditure of the program is around $€ 850$ million ( $\$ 1,251$ million USD) in 2008. Companies that joined the Energy Agreements Programme (EAP), established in 2006, can also be members of the LIEN. In 2007, eleven companies became LIEN members via the EAP. Figure 5 shows the membership in both the LIEN and EAP programs.

\section{Energy Savings and GHG Emissions Reductions Realized}

Under the LIEN program, changes of year-on-year energy intensity (energy consumption per unit of product) in each member company are used to calculate energy savings. In other words, energy savings are the difference between actual energy consumption and what would have been consumed if the energy intensity of each member remained at the level of previous year.

According to the LIEN 2007 Annual Report, energy saved due to energy-efficient measures was $1,753 \mathrm{GWh}$ by the end of 2007. LIEN members avoided $432,260 \mathrm{tCO}_{2}$ that year as well, which was about $8.5 \%$ of the total $\mathrm{CO}_{2}$ emissions in Ireland. Energy savings in 2007 were $6.9 \%$ less than what would have been consumed at the 2006 energy intensity level (SEI \& LIEN, 2008). In 2008, energy saving improvement by LIEN members was $5.2 \%$, resulting in avoided energy expenditures of over $€ 60$ million ( $\$ 88$ million USD) and a reduction of 349,000 $\mathrm{tCO}_{2}$ (SEI \& LIEN, 2009).

Overall, compared to 1995, the founding members of LIEN realized an average energyefficiency improvement of $30 \%(4,150 \mathrm{GWh})$ in 2008, with a year-on-year average energy savings of 3\% (Gudbjerg, 2009). Table 2 below displays the percentages of energy efficiency gains over the 2006-2008 period. The energy demand of LIEN members was growing at or more than $20 \%$ from 2006-2008, with the number of LIEN members (also include companies in the Energy Agreement Program) increased significantly. Correspondingly, the share of energy demand of LIEN in the national total also grew at double-digit rates. Energy avoided in 2006 in the LIEN program was relatively small compared to that of 2007 and 2008.

Table 2. Overall Performance of LIEN Members, 2006-2008

\begin{tabular}{|c|c|c|c|c|c|}
\hline & $\begin{array}{c}\text { LIEN Total } \\
\text { Primary Energy } \\
\text { Requirement } \\
\text { (GWh) }\end{array}$ & $\begin{array}{c}\text { Total National } \\
\text { Energy } \\
\text { Requirement } \\
\text { (GWh) }\end{array}$ & $\begin{array}{c}\text { LIEN Share of Total } \\
\text { National Energy } \\
\text { Requirement } \\
(\%)\end{array}$ & $\begin{array}{c}\text { Avoided } \\
\text { Energy } \\
\text { (GWh) }\end{array}$ & $\begin{array}{c}\text { Share of } \\
\text { Avoided } \\
\text { Energy } \\
(\%)\end{array}$ \\
\hline 2006 & 17,342 & 172,000 & $10 \%$ & 543 & $3.1 \%$ \\
\hline 2007 & 20,732 & 187,429 & $11 \%$ & 1,753 & $6.9 \%$ \\
\hline 2008 & 26,600 & 190,488 & $14 \%$ & 1,620 & $5.2 \%$ \\
\hline
\end{tabular}

Source: SEI \& LIEN, 2007-2009.

Note: Total Primary Energy Requirement (TPER) includes total energy consumption and energy used in transforming primary sources of energy. Here TEPR is converted to electricity units. 
The breakdown of LIEN members by industrial sub-sector as well as the sectoral energy efficiency contribution under the LIEN program is provided in Table 3. It is worth noting that the output of two largest sectors (food/drinks and other) in the LIEN decreased $4 \%$ in 2008 , and these two sectors account for more than $75 \%$ of the total energy demand within the LIEN. On the other hand, the electronics sector had a $4 \%$ increase in output, but realized a 6.93\% improvement in energy efficiency.

Table 3. Performance of LIEN Members by Industrial Sub-Sector, 2007-2008

\begin{tabular}{|l|c|c|c|c|}
\hline & $\begin{array}{c}\text { Share of } \\
\text { Energy } \\
\text { Demand in } \\
\text { LIEN (\%) }\end{array}$ & $\begin{array}{c}\text { Change in Energy } \\
\text { Demand in Total } \\
\text { Primary Energy } \\
\text { Demand (\%) }\end{array}$ & $\begin{array}{c}\text { Change in } \\
\text { Output } \\
(\%)\end{array}$ & $\begin{array}{c}\text { Energy } \\
\text { Efficiency } \\
\text { Gains/Losses } \\
(\%)\end{array}$ \\
\hline Healthcare & $4 \%$ & $7 \%$ & $9 \%$ & $1.87 \%$ \\
\hline Pharmaceutical /Chemicals & $10 \%$ & $-1 \%$ & $1 \%$ & $4.53 \%$ \\
\hline Electronics & $10 \%$ & $-3 \%$ & $4 \%$ & $6.93 \%$ \\
\hline Food/Drinks & $14 \%$ & $-4 \%$ & $-3 \%$ & $2.38 \%$ \\
\hline Other & $62 \%$ & $-4 \%$ & $-3 \%$ & $6.51 \%$ \\
\hline
\end{tabular}

Source: SEI \& LIEN, 2009.

\section{Specific Actions Undertaken by Manufacturers}

As a requirement for joining the LIEN program, participating companies commit to take actions to develop an energy management program, set energy targets, carry out annual energy audits, produce annual statements on energy consumption, and have a review of energy targets through monitoring and publicizing.

Universal energy-efficient measures, such as efficient lighting, refrigeration, compressed air systems, motors, fans, combined heat and power systems, and variable speed drives, have been used widely across different sectors (OMP, 2008). To identify issues and energy-saving opportunities, on-site surveys and energy audits were carried out before implementation of technologies and measures. Energy awareness campaigns and staff training on energy-related issues have also been used within companies (SEI\& LIEN, 2009). The Energy Management Action Plan (MAP) program is also utilized by companies (this program is described further below).

In addition to the cross-cutting energy-saving technologies and measures listed above, other measures have been implemented in different sectors as well (SEI \& LIEN, 20072009).

Pharmaceutical/chemicals sector:

- Installation of new chiller systems or optimization of chillers

- Reduction of steam pressure from boilers

- Conversion of satellite boilers to natural gas

- Optimization of air changes in process areas

- Upgrades of piping or leak reduction projects

- Lowered warming settings on standby boilers

- Improved Heating/cooling system maintenance 
- Assessment of HVAC system and optimization

- Change of product portfolio

Food and drink sector:

- Heat recovery projects

- Nano filtration technology to reduce energy consumption

- Conversion of main boilers to burn tallow instead of MFO

- Installation of boiler economizer on gas-fired boiler

- Installation of steam mass flowmeter on Brew House kettle

- Production of hot water from burning tallow

- Upgrade of utility metering systems

- Process controls (on evaporation and drying plants)

- Installation of Clean in Place (CIP) system

Other sectors:

- PC automatic standby program

- Office energy saving programs

- Process control to sequence correct operation of equipment

- Upgrades of equipment and processes

- Upgrades of HVAC systems and optimization

\section{Energy Agreement Program}

Launched in 2006, the goal of the Energy Agreement Programme (EAP) is to support annual reductions of $1 \%$ in national energy consumption. As a subset of the LIEN, the EAP aims to include the largest industrial energy enterprises in Ireland, with the goal of protecting enterprises from repeated low-quality energy-efficiency projects while providing them the opportunities and methods of best practice energy management through a scheduled process.

\section{Program Design}

Structure

The EAP for industry was launched by the National Standards Authority of Ireland (NASI), while Sustainable Energy Ireland (SEI) provides services and support to the EAP members. A key element in EAP - the Irish Energy Management System Standard IS393 was developed by SEI by working with NSAI as well as industry representatives.

\section{Commitments and Benefits}

All members in this program are required to obtain the certificate of the new Irish Energy Management System IS393 and to implement the standard to maximize energyefficiency gains through signing a three-year contract with SEI. IS393, which covers all aspects of a company's approach to managing energy, is a similar and compatible with the Environmental Management System Standard ISO14001. The maximum time for companies to obtain the IS393 certificate is two years, while there is also an established "best endeavor", which is within 12 months. As of 2008, 28 companies were certified with IS393 implemented onsite (1 in 2006, 9 in 2007 and 18 in 2008). 
In addition, companies in the EAP program also commit to conduct and complete three Special Investigations with an emphasis on applying energy-efficient technologies and/or key processes in energy-intensive areas. The three Special Investigations must be conducted during an initial three-year period, and yearly data on energy performance must be provided to SEI (Gudbjerg, 2009).

The process (as displayed in Figure 6) for EAP members to implement IS393 starts with undertaking Special Investigations, followed by data collection to analyze the current energy-use conditions, and then taking actions to address identified issues. Compliance with IS393 is certified by a third-party party (McKane, et al., 2007).

While the EAP members are undergoing the implementation of IS393, SEI provides advice and support, financial assistance, Special Working Groups to identify energysaving opportunities, and Special Initiatives that are designed for specific areas. Also, SEI offers tailor-made training, mentoring and advice to companies that have made progress. More than 1,000 firms have received energy-efficient expertise from SEI.

Figure 6. The Process of Implementing IS393

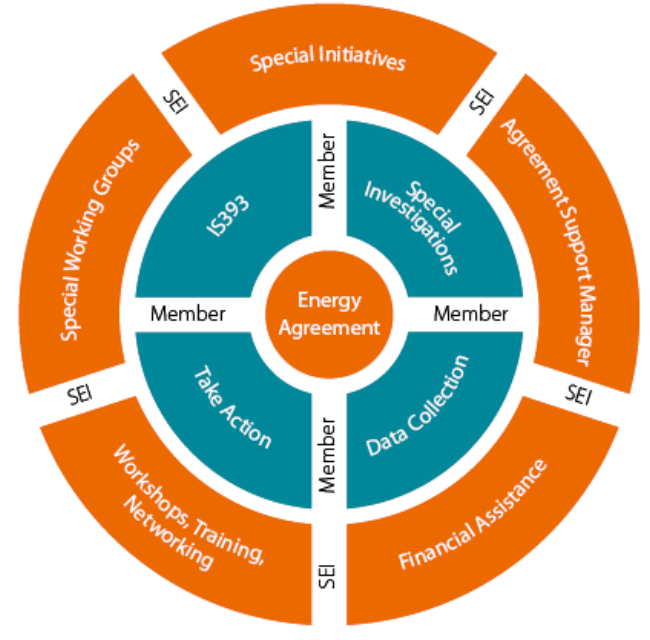

Source: SEI \& LIEN, 2008.

SEI also provides facility auditing to the EAP members through the Agreement Gap Analysis (AGA). The auditing and analysis are conducted by independent experts who are local consultants trained by SEI. AGA auditors determine the gap between a company's current status in energy use and the requirements of IS393. They will further provide advice and suggestions on what measures the company can take to address the identified issues. The Irish National Accreditation Body then verifies the auditing and analysis results. The costs are covered by SEI "up to a pre-agreed amount."

With the issuance of the European energy management standard EN 16001, which is based on the Irish standard IS393, in July 2009, companies under the EAP program are now required to adopt or upgrade to EN 16001:2009 by July 2010 (SEI \& LIEN, 2009). 


\section{Compliance}

As with LIEN, EAP is a voluntary program so there are no compliance mechanisms associated with participation. Industries are free to join or withdraw from EAP as they wish. As members of EAP, there are no penalties for non-compliance with EAP goals. However, as described above, member companies are required to obtain IS393 Energy Management System certification within two years as well as undertaking three Special Investigations.

\section{Industry Participation}

The EAP is targeted at large, energy-intensive enterprises with high energy costs. Participants of the EAP are required to have an annual energy bill of $€ 2$ million ( $~ \$ 2.9$ million USD) or more with high exposure to energy costs. By 2007, 60 companies signed agreements with SEI, with a breakdown shown in Figure 7 (SEI \& LIEN, 2008). In 2008, the number of companies in EAP increased to 80 (Gudbjerg, 2009).

Figure 7. Industrial Participation in the EAP (2007)

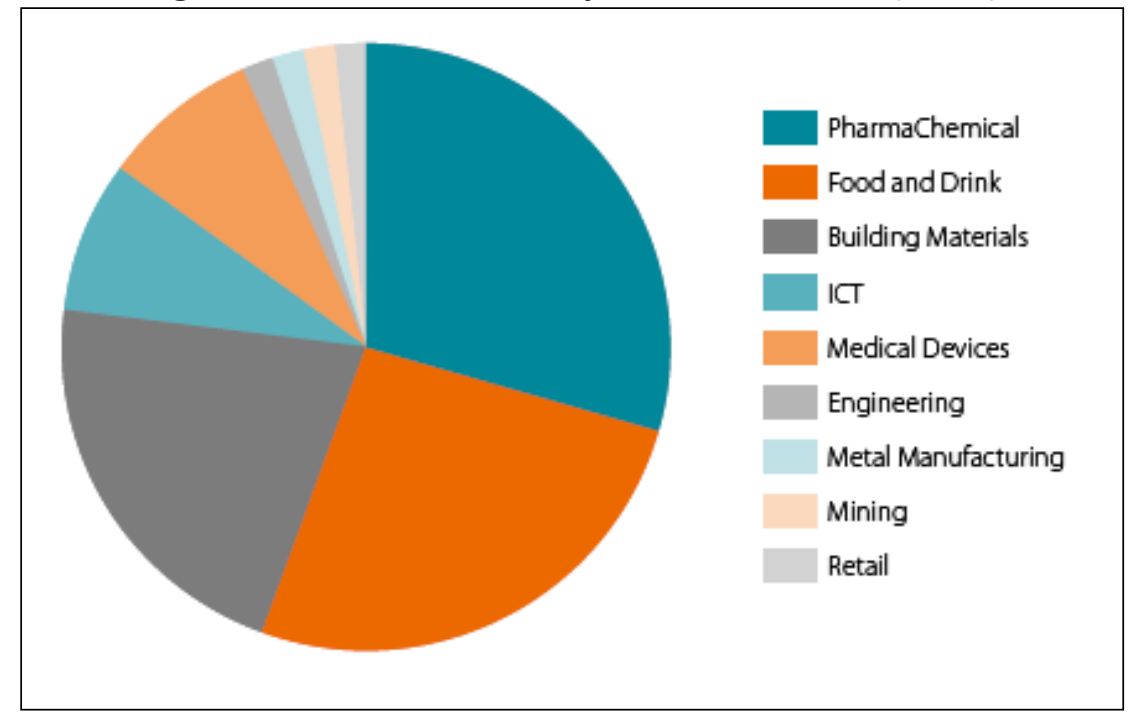

Source: SEI \& LIEN, 2008.

\section{Energy Savings and GHG Emissions Reductions Realized}

Because the EAP is a subgroup of the LIEN, energy savings or avoided emissions from EAP members are included in the annual results of the LIEN (presented above). However, differences between the EAP members and LIEN-only companies can still be observed.

Since the EAP was established in 2006, companies in the EAP have generally performed better than companies that only joined the LIEN. In 2008, the EAP members' total primary energy consumption represented $52 \%$ of the total energy consumption of the LIEN. But in both 2007 and 2008 EAP members realized a much higher energy-efficiency improvement than LIEN-only members, as shown in Table 4. In addition, in 2007 twothirds of the companies that reported their yearly energy data were participants in the EAP (SEI \& LIEN, 2008). 
Table 4. Performance Comparison: LIEN-only vs. EAP

\begin{tabular}{|l|c|c|}
\hline Energy efficiency gains & $\mathbf{2 0 0 7}$ & $\mathbf{2 0 0 8}$ \\
\hline LIEN-only companies & $1 \%$ & $4.7 \%$ \\
\hline EAP members & $8 \%$ & $6 \%$ \\
\hline
\end{tabular}

Source: SEI \& LIEN, 2009.

\section{Specific Actions Undertaken by Manufacturers}

Companies that participate in the EAP program are required to undertake energy-saving actions and energy-efficient measures in order to obtain the certificate of IS393 Irish Energy Management System in two years. In addition, three Special Investigations need to be undertaken by focusing on companies' core processes.

Companies in the EAP or LIEN programs can also join the Special Working Groups organized by SEI every year to focus on energy-management technologies and best practices in specific areas. Typically, in the Special Working Groups, the activities include "site assessments, audits, demonstration projects, special investigations, desktop research, design of experiments, methodology development, new tools and new solutions development" (SEI \& LIEN, 2009). In 2008, energy-efficient design, HVAC, refrigeration optimization and alternative methodologies were covered in the Special Working Groups (DCENR, 2009b).

\section{Assessments and Evaluation}

An evaluation survey conducted by SEI on 22 companies that were certified to the Irish energy management standard (IS393) during 2007-2008, showed that:

- " $90 \%$ of the companies need 6-18 months to implement IS393;

- $64 \%$ of the companies decided to integrate IS393 with other standards;

- All companies have integrated IS393 with ISO 14001, while 20\% integrated with ISO 9001 and OHSAS 18001;

- Most criteria for integration were achieved with the exception of reducing energy audit time;

- SEl program showed effective but grant incentives for special investigations were not greatly availed of during implementing the energy management system" (Gudbjerg, 2009)

\section{Other facilitating programs:}

\section{Energy Management Action Plan (Energy MAP):}

Energy Management Action Plan (Energy MAP) aims to engage businesses and industrial companies "in the appropriate level" of energy management in order to maximize their energy efficiency. It is a program open to all sizes of companies, and is "geared toward smaller or less technical resourced firms" (DCENR, 2009b).

The Energy MAP provides an online tool along with other energy-management resources. The tool and resources provide advice on both the managerial and technical aspects of energy efficiency. Although the Energy MAP addresses a wider audience, it has the same principles as the IS393 standard, which is required for EAP members. 
For energy managers at industrial companies, the Energy MAP tool guides them through a step-by-step best practice action plan, which is composed of 20 steps. The 20 steps are divided into "five pillars of excellent energy management": commit, identify, plan, take action and review. In addition, SEI offers tailored training courses on specific areas or sectors, and provides introductions to energy management.

\section{Accelerated Capital Allowances (ACA):}

In 2008, a new tax incentive was introduced through the Accelerated Capital Allowances (ACA) scheme, which was designed to encourage industrial companies (both large and small industrial enterprises) to procure the most energy-efficient equipment. Companies can deduct the full costs of purchased eligible energy-efficient equipment from their profits in the year of purchase.

At this stage, a wide range of products (about 5,000) are now under the scheme (SEI \& LIEN, 2009; DCENR, 2009b). In phase 1 of the ACA scheme, five categories of products were included: lighting, lighting controls, motors, variable speed drives, and building energy management systems (S.I., 2008). In 2009, 24 additional technologies/products were added to the list, which include electric and part-electric vehicles and associated charging equipment, alternative energy vehicle conversion, IT infrastructure hardware and associated cooling equipment, electricity-generation equipment (plant self-use, such as solar PV, wind turbines, CHP and anaerobic digestion equipment), boiler equipment and control and recovery systems, HVAC systems, and advanced liquid-and gas-handling equipment (S.I. 2009). The detailed list of technologies can be found at the website of Sustainable Energy Ireland (SEI, 2009c). The Irish government estimated that the expanded ACA scheme covers "technologies responsible for $60 \%$ of the industrial energy use in Ireland” (DCENR, 2009a).

This scheme will enable enterprises (including LIEN members) to "write off the entire cost of energy-efficient equipment in the year of purchase," and thus to encourage more investments in energy-saving technologies and products. 


\subsubsection{France - Program with Threat of Taxes or Regulation}

In France, the first negotiated agreements between companies and the French Ministry of Environment to reduced GHG emissions were signed in 1996, but only by a few companies. Then, in 2002, a larger number of companies and branch organizations came together and created an association called the Association des Entreprises pour la Reduction de l'Effet de Serre (AERES), or the French Association of Companies for the Reduction of Greenhouse Gases. AERES was created to pool resources in order to facilitate the process of signing negotiated voluntary agreements. Overall, 29 corporations and four industry associations committed themselves to reduce their GHG emissions over the period $2003-2007$ by $15 \%$ all together.

\section{Program Design}

Structure

AERES is a non-binding agreement program which is not integrated with other French policy measures. The uniqueness of the French scheme was the extensive direct management of the companies who organized themselves to initiate and administer the agreements, and the government only needed to approve them. In exchange, the government agreed that no carbon taxation would be applied towards the industry sector.

The AERES commitment scope was wider than the scope of the European Directive on $\mathrm{CO}_{2}$ emissions credits, and therefore wider than the scope of the emissions credits in the National Allocation Plan, as it covers other sectors than those defined by the Annex 1 of the Directive, and the six GHGs of the Kyoto protocol.

The AERES program is unique in that companies pooled together to form an association with the only goal of administering voluntary GHG emission reduction commitments. The association examined, approved, registered and controlled the implementation of each participating company's commitments. The management of the program was independent from the government and organized by the association.

AERES was composed of an Executive Board and a Consultative Committee. The Consultative Committee had approximately 30 members, including two experts and four observers designated by the government. Its role was to examine each engagement and inform the executive board about the robustness of the engagement and its conformity with the requirements of the general framework agreement signed by each member when joining the association. The board then decided whether or not to approve the commitments. The participation of the French government was minimal. It approved the general framework agreement signed by each member and appointed four observers and an expert to the AERES Technical Consultative Committee (AERES, 2008). The Consultative Committee provided advice on the seriousness of the company's commitment proposals. 


\section{Commitments and Benefits}

The AERES program consisted of negotiated agreements between corporations or industry branches and the government. The negotiation process was organized as a "standard procedure," by which firms were to provide information on past $\mathrm{CO}_{2}$ emissions, discuss feasible energy saving or substitution measures, and set quantitative objectives for $\mathrm{GHG}$ reduction in specific terms (i.e. per unit of production) or in absolute terms for the period. Reductions in absolute emissions were given according to a hypothetical projected production levels.

In order to facilitate the negotiation process, AERES designed a standard agreement text with ground rules for each agreement which included the type of GHG concerned, the period of reference, the scope, the objective, the means that were needed to succeed, the monitoring process and sanctions. The standard agreement text also included two provisions in the case of special situations due to significant incidents or if the effective production was higher than the forecasted production within the framework of an absolute target.

The commitments of the AERES members applied to two periods (2003-2004 and 20052007) and varied across companies, depending on individual potential savings and production forecasts. Each member committed themselves to publish a report with their current emissions and their reduction targets. The report was called the commitment book "le livres des engagement" and described the targets for the reduction of the six Kyoto Protocol GHGs: $\mathrm{CO}_{2}, \mathrm{CH} 4, \mathrm{~N} 2, \mathrm{HFCs}$, PFCs, and SF6. Companies reported only direct emissions, meaning that no emissions were accounted for electricity consumption. However, since some of the key electricity producers were part of the AERES scheme, emissions related to electricity production were accounted upstream and also affected by reduction targets. Commitments were set either as absolute targets (in $\mathrm{CO}_{2}$-eq tons), or as relative targets (in $\mathrm{CO}_{2}$-eq tons per product unit) and $\mathrm{GHG}$ emissions data was verified each year by independent organizations.

Each corporation followed common quantification, reporting, and verification guidelines of the protocol elaborated by another association called Entreprise pour L'Evironnement (EpE). The principles are in accordance with those defined by the French administration and the World Business Council for Sustainable Development/World Resources Institute (WBCSD/WRI) GHG Protocol Initiative. Verification by third party was mandatory. AERES established a methodology for quantifying and taking into account early actions and combined heat \& power (CHP) plants. The consolidation of GHG emissions data was verified each year by independent organizations.

In addition to avoiding a carbon tax, benefits of signing the agreements included increased environmental awareness and use of environmental management systems in companies. 


\section{Compliance}

If commitments were not fulfilled, AERES members could exchange emissions credits within the framework of an AERES internal market, with companies which did better than their commitment. During the second period 2005-2007, it was also possible to use $\mathrm{CO}_{2}$ credits bought on the European market and returned to the French administration in addition to the credits initially distributed by the government. If a company did not fulfill its commitments in spite of using the means described above, it would have had to pay a penalty of $€ 10 / \mathrm{tCO}_{2}$ eq (US $\left.\$ 14.6\right)^{7}$ (AERES, 2009). The proceeds of these penalties were designed to be used to finance research and collective actions regarding climate change, and to involve small and medium companies into the system. However, at the end of the second commitment period, no companies had to pay a penalty fee.

The agreements also included two provisions in case of significant incidents or if the effective production was higher than the forecasted production within the framework of an absolute target. In this last case a corrective term was calculated corresponding to the product of the production difference by the relative emission corresponding to the commitment. A company could request a revision of its commitment, particularly if there was a change in the company boundaries or in the GHG emissions quantification methodology. The company submitted a document to AERES, which was submitted to the Consultative Committee for advice, then to the Board of AERES for validation. In 2007, 3 commitments were revised due to the sale of physical assets.

\section{Industry Participation}

In 2007, AERES members included 29 corporations and four industry associations, representing $50 \%$ of $2006 \mathrm{GHG}$ emissions of the French industry (including the energy industry) and $18 \%$ of total 2006 GHG emissions in France. One of the unique features of the French agreements is that a large proportion of the participants were from the energy sector. As shown in Table 5, 66\% of the energy sector emissions and about $41 \%$ of the manufacturing sector emissions were included in the AERES scheme. Table 5 also shows the participation by individual industry sub-sectors. For example, $87 \%$ of the emissions from the refinery sector are included in the AERES scheme, while the representation of the pulp and paper sector is only $9 \%$ of that sector's emission.

Table 5 also displays the emissions commitment for each industry subsector. The collective AERES engagement was to reduce emissions by 15\% over 1990 levels by 2007 . Commitments differed greatly among individual subsectors, with the non ferrous metal industry having the highest reduction commitment of $44 \%$ and the refinery and food sectors committing to increase emissions by only $23 \%$. However, these commitments are in absolute terms and do not necessarily reflect individual subsector efforts. The refinery and the food sectors saw their production increase sharply since 1990. In the case of the refinery sector new regulations have required the industry to produce cleaner refinery output which necessitates greater amounts of fuel use.

\footnotetext{
${ }^{7} 2008$ exchange rate of $0.68 €$ per US\$ (OECD, 2009).
} 
Table 5. AERES Membership and Commitment Emission Reduction Commitment by Industrial Sub-Sector

\begin{tabular}{|l|c|c|c|}
\hline & $\begin{array}{c}\text { Member's Share in the } \\
\text { Energy and Manufacturing } \\
\text { Sector's Emissions }\end{array}$ & $\begin{array}{c}\text { Member's Share in } \\
\text { Subsector's } \\
\text { Emissions }\end{array}$ & $\begin{array}{c}\text { Commitment } \\
\text { Emissions reduction }\end{array}$ \\
\hline Energy Sector & $\mathbf{6 6 \%}$ & $\mathrm{NA}$ & $\mathbf{+ 5 \%}$ \\
\hline Electricity Production & $44 \%$ & $87 \%$ & $-0.7 \%$ \\
Refinery & $22 \%$ & $\mathbf{+ 2 3 \%}$ \\
\hline Manufacturing & $\mathbf{4 1 \%}$ & $\mathrm{NA}$ & $\mathbf{- 2 6 \%}$ \\
\hline Iron and Steel & $17 \%$ & $24 \%$ & $-11 \%$ \\
Food & $3 \%$ & $39 \%$ & $+23 \%$ \\
Chemical & $8 \%$ & $63 \%$ & $-46 \%$ \\
Cement & $8 \%$ & $\mathrm{NA}$ & $-\mathbf{2 8 \%}$ \\
Non ferrous metal & $2 \%$ & $9 \%$ & $-5 \%$ \\
Pulp and paper & $0.4 \%$ & $69 \%$ & $+10 \%$ \\
Glass & $2 \%$ & - & $-15 \%$ \\
\hline Total & - & & \\
\hline
\end{tabular}

Source: AERES, 2009

\section{Energy Savings and GHG Emissions Reductions Realized}

According to the final assessment report (AERES, 2009), overall commitments were met and even largely surpassed. Companies collectively committed to reduce emissions by $20 \mathrm{MtCO}_{2}$ eq. in 2007 compared to 1990. In reality, they reduced emissions by 33.7 $\mathrm{MtCO}_{2}$ eq., which is a reduction of $25 \%$ (Figure 8 ).

\section{Figure 8. GHG Emissions from AERES Members and Overall Targets ( $\mathrm{MtCO}_{2}$ eq.)}

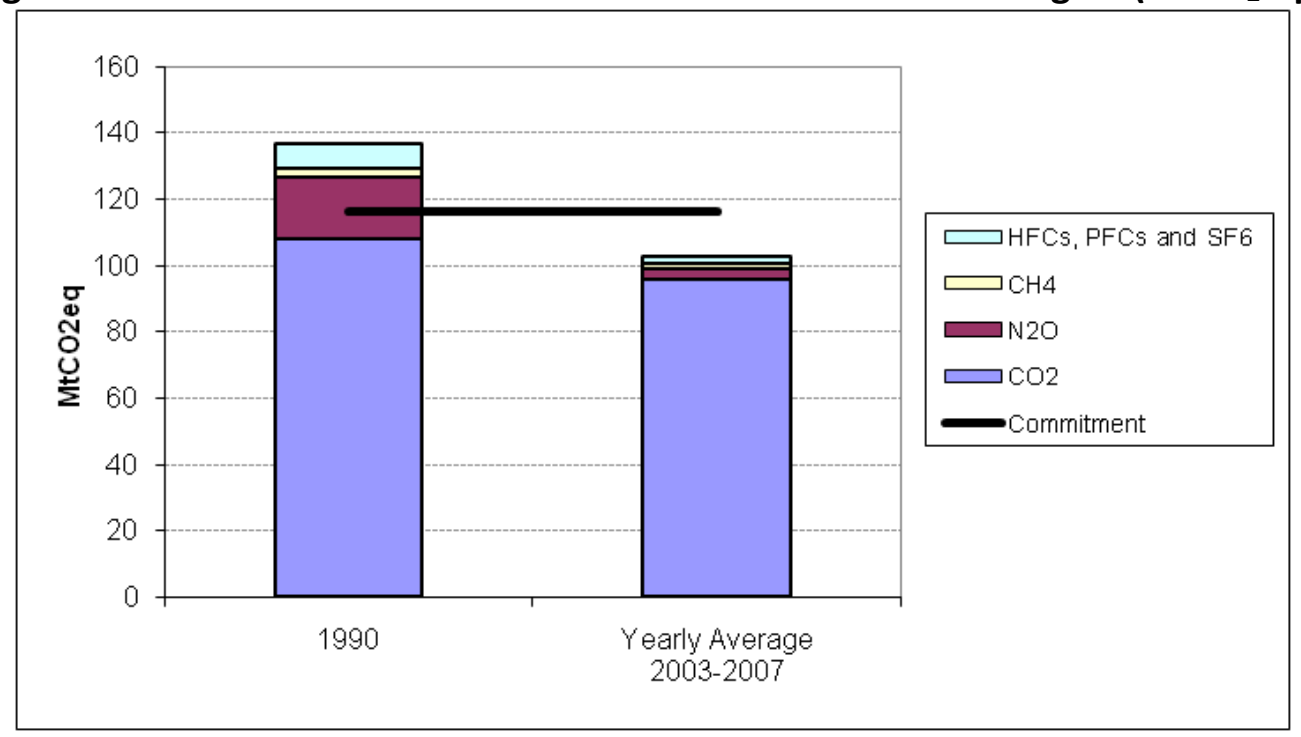

Source: AERES, 2009.

Emissions reductions were uneven across the GHGs. The largest reductions were of $\mathrm{N}_{2} \mathrm{O}$ (84\%) and HFCs, PFCs and SF6 (70\%). However these emissions represented only a small share of total emissions, while $\mathrm{CO}_{2}$ emissions represented the vast majority of emissions. If only manufacturing industries are considered, the overall reduction was $34 \%$, which 
considerably surpasses the initial commitments of $27 \%$. The energy industry reduced emissions by $11 \%$ compared to an initial commitment of a $4 \%$ increase.

As shown in Table 6, results also differed across manufacturing subsectors, with the chemical and aluminium industries showing the largest GHG reductions. Most companies achieved more ambitious reductions than their original targets. Of the total of 31 companies in AERES, five did not reach their targets. These were from the cement, chemical, and glass industries. As agreed in the AERES framework document, these compliance gaps were compensated with early action credits and exchange of credits with other companies from AERES.

In addition, four companies dropped their participation in AERES and did not renew their engagement for the second period. Finally, three commitments were revised due to changes in the company boundaries. These revisions were submitted to the Consultative Committee for advice and were then validated by the Board of AERES.

Table 6. GHG Emissions Targets and Realized Reductions by Industry Subsectors

\begin{tabular}{|c|c|c|c|c|}
\hline & $\begin{array}{l}\text { Commitment } \\
\text { Emission } \\
\text { reduction }\end{array}$ & $\begin{array}{c}1990 \\
\text { Emissions } \\
\text { (Mt CO } 2 \text { eq.) }\end{array}$ & $\begin{array}{l}\text { 2003-07 Average } \\
\text { Emissions } \\
\text { (Mt CO } \mathrm{C}_{2} \text { eq.) }\end{array}$ & $\begin{array}{c}\text { Emissions } \\
\text { Reduction Realized } \\
\left(\mathrm{Mt} \mathrm{CO}_{2} \text { eq. }\right)\end{array}$ \\
\hline Energy Sector & $5 \%$ & 53.91 & 45.37 & $-16 \%$ \\
\hline Electricity & $-0.70 \%$ & 37.76 & 30.21 & $-20 \%$ \\
\hline \multirow[t]{2}{*}{ Refinery } & $23 \%$ & 13.31 & 15.16 & $14 \%$ \\
\hline & $-10 \%$ & 2.84 & 2.54 & $-11 \%$ \\
\hline Manufacturing & $-26 \%$ & 82.82 & 55.14 & $-33 \%$ \\
\hline Iron and Steel & $-11 \%$ & 29.69 & 25.43 & $-14 \%$ \\
\hline Food & $23 \%$ & 3.14 & 3.13 & $-1 \%$ \\
\hline Chemical & $-46 \%$ & 29.82 & 11.49 & $-61 \%$ \\
\hline Cement & $-28 \%$ & 12.10 & 9.27 & $-23 \%$ \\
\hline Non ferrous metal & $-44 \%$ & 4.65 & 2.36 & $-49 \%$ \\
\hline Pulp and paper & $-5 \%$ & 0.60 & 0.47 & $-21 \%$ \\
\hline Glass & $10 \%$ & 2.81 & 3.00 & $7 \%$ \\
\hline Total & $-15 \%$ & 136.73 & 100.51 & $-26 \%$ \\
\hline
\end{tabular}

Source: AERES, 2009

\section{Specific Actions Undertaken by Manufacturers}

Some key specific actions undertaken by manufacturers are described in the final assessment report (AERES, 2009). Some measures are common to all sectors. They include recycling, fuel switching, and cogeneration. These measures can often be applied in many subsectors and have proven to be effective in reducing emissions.

A more detailed analysis at the sectoral level highlights what were some of the successful measures: 
Iron and Steel: A large part of the emissions reduction was realized through an increase in recycling rates of scrap steel. Production of steel from steel scrap requires only a third of the energy required for producing steel from raw material.

Chemicals: In the chemicals industry, emissions were reduced by removing or recycling some of the GHGs emitted, such as through:

- the capture and destruction of perfluorocarbon gases by thermal oxidation

- the oxidation of nitrous oxide $\left(\mathrm{N}_{2} \mathrm{O}\right)$ in nitric oxide (NO) which is then recycled to produce nitric acid for use in production of nylon and in the semiconductor industry for various processes

- the catalyst reduction of $\mathrm{N}_{2} \mathrm{O}$ in nitrogen and oxygen to produce glyoxal

Also some reduction was realized through the installation of cogeneration natural gas plants.

Cement: The cement industry reduced its emissions by using alternative fuels that emit less or no GHG when combusted and by increasing the use of recycled products. For example, clinker was replaced by alternative cementitious materials such as fly ash and blast furnace slag. Implementation of energy efficiency measures also allowed this industry to reduce the energy intensity of producing cement.

Non Ferrous Metals: Emissions of perfluorocarbons gases in the aluminium industry were considerably reduced by implementing computerized controls and point-feeder systems. The use of SF6 in the production of magnesium was in part substituted. Recycling of aluminium also considerably reduced emissions as secondary aluminium production requires only $10 \%$ of the energy required in primary production.

Pulp and Paper: In the pulp and paper industry, companies used biomass as a substitution to fuel use. They also implemented cogeneration plants and have increased the energy efficiency of their industrial process.

Refineries: Most of the GHG emission reductions in the refinery sector are due to energy savings. Energy savings resulted from the implementation of advanced control systems and heat integration. Also the installation of cogeneration has allowed this industry to reduce energy use.

Natural Gas Supply System: Two major measures were undertaken to reduce the energy used by the natural gas supply system. These include the replacement of some gas main canalization that were in cast iron with polyethylene canalization and the replacement of motor-compressors with turbo-compressors or electro-compressors.

Glass: Measures implemented in the glass industry included the increased use of recycled glass and the development of waste sorting by color. Other important measures include heat recovery and better heat integration. For one glass plant, heat was also recovered from the exhaust flue and used to heat buildings. 


\section{Assessment and Evaluation}

It is difficult to assess the relative influence that the AERES agreements had on the observed reductions of emissions (Chidiak, 2002). No evaluations have been conducted to assess how much of the realized saving are the direct consequences of signing the agreements. Critics have raised concerns regarding the real commitment of the enterprises. Some believe that the reduction in energy intensity would have happened for most companies without affiliating with AERES. Even in the final AERES report itself, it is recognized that companies knew before signing the agreements that they would reduce their emissions over the next 5 years, because investments in industries are a very long term process.

Analysis from two case studies in the aluminium and in the packaging glass industries suggested that the considerable reductions in specific GHG emissions could hardly be seen as a direct consequence of the commitments. Instead they seemed to have been triggered by other environmental regulations, and above all, by industry's heavy investments in technology modernization and cost reduction efforts, made before the AERES agreements (Chidiak, 2002). A clear benefit of the AERES program was that the companies learned about emissions management since for most of them it was the first time they dealt with monitoring their GHG emissions.

Third party consultation in AERES was non-existent. During negotiations, there was no consultation between the main actors and environmental groups. The AERES Consultative Committee was mostly composed of industry representatives. Only two government representatives that are industry experts were involved in the process. It seems that no thorough discussion of industry's abatement possibilities was pursued with external actors.

Benefits of the French AERES agreements were the development of an intra-sectoral dialogue regarding energy issues, which were traditionally regarded by firms as too sensitive for their competitive positions to allow for information disclosure. According to AERES members, it was also very useful for the industrial sector to learn about GHG inventory methodology, GHG emission reduction potentials, and energy efficiency. The government also benefitted from the opportunity to collect data on individual company emissions and gained knowledge regarding industry savings potentials. Finally, another positive aspect of the French system is that the cost was relatively low as little or no public entities were required to administer the scheme. Implementation and monitoring took place on the basis of self reported data collected by companies or branch associations. 


\subsubsection{Netherlands - Program with Threat of Taxes or Regulation}

The Netherlands established its first Long-Term Agreement (LTA) program in 1989. This program, referred to now as the LTA1 program, ended in 2000. At that time, the LTA2 and Benchmarking Covenants programs were initiated. These two programs were scheduled to extend until 2012, but were converted to the LTA3 program in 2008.

\section{Long-Term Agreements - First Phase (LTA1)}

The Dutch government issued the National Environmental Policy Plan in 1989 which outlined a national target for reduction of $\mathrm{CO}_{2}$ emissions by $3 \%$ in 2000 compared to a 1989 base year (NEPP, 1989; Gerrits and Oudshoff, 2003; Kerssemeeckers, 2002). The goal was translated into an improvement in energy efficiency of $20 \%$ over the same time period and the LTA1 agreements were initiated with the aim of achieving the goal without resorting to new regulations (Gerrits and Oudshoff, 2003). The LTAs were contracts under civil law which were legally binding and pre-empted future regulatory requirements.

\section{Program Design}

$\underline{\text { Structure }}$

The LTA1s were voluntary agreements between the Dutch Ministries and industrial subsectors that consumed more than 1 petajoule (PJ) per year. The agreements were established through the Energy Conservation Memorandum of 1990, were negotiated between government and industry associations over a two-year period, and were signed in 1992. The sectors included in the agreements were required to have homogenous processes and products as well as an active sector association (SenterNovem, 2001). Each industry association signed an agreement with the Dutch Ministry of Economic Affairs committing to achieve specific energy efficiency improvements by 2000 .

\section{Commitments and Benefits}

The overall commitment for industry under the LTA1s was a $20 \%$ increase in energy efficiency over 1989 levels by 2000. The commitments were divided among the various industrial sectors with most industries also adopting a target of $20 \%$ reduction, but some establishing different targets based on assessments of their energy-efficiency potential. For example, the petroleum refining industry's overall commitment was a $10 \%$ reduction, while the target for Philips Lighting was a $25 \%$ reduction. The process for establishing the industrial sector targets began with a preliminary assessment of the energy efficiency potential of the sector by the industry. NOVEM, ${ }^{8}$ the Dutch Agency for Energy and Environment, established an inventory of economically-viable measures that could be implemented by the companies and based on this inventory set a target for energy efficiency improvement for each sector (Nuijen and Booij, 2002).

Individual company commitments under the LTA1s included the preparation of an energy conservation plan (ECP) and monitoring energy efficiency activities using an energy efficiency index (EEI). The ECPs listed the energy efficiency measures that the

\footnotetext{
${ }^{8}$ Later renamed SenterNovem, now NL Agency.
} 
company planned to undertake to meet its target and provided documentation of how the energy efficiency savings were to be measured. All companies were required to report the results of their energy monitoring, as well as the implemented projects, annually. Based on the performance, the Energy Savings Plan was adapted in order to achieve the agreed-upon target. The Energy Savings Plan, monitoring reports, and company-level EEls were confidential but were reviewed by NOVEM for accuracy and completeness (SenterNovem, 2001).

Individual companies and industrial sub-sectors were also required to prepare LongTerm Plan (LTPS) to describe how they planned to realize the targets. Energy assessments were used as a basis for the LTPs, which included evaluation of energy consumption in the base year, a survey of opportunities for energy-efficiency improvement, company energy plans, monitoring and energy management in each company, research and development of new low-energy technologies, demonstration projects for energy savings measures, assistance to individual companies, and information dissemination (Nuijen, 1998). The individual company plans provided the basis for the sector-wide plan. Once the Long Term Plan was established, the Long Term Agreement was signed by the industry association, the Ministry of Economic Affairs, and NOVEM.

NOVEM provided support to the program through the following (Kerssemeeckers, 2002):

- Making preparations for signing declarations of intent and the LTAs.

- Supporting industrial branches and individual firms providing financial support through subsidy schemes (described below) to carry out feasibility studies, research, development and demonstration projects.

- Monitoring of the LTAs through verifying the firm-level progress reports and preparing official statistics.

- Supporting knowledge sharing on energy-efficiency improvement among industrial sectors.

Individual plant audits conducted as part of the Dutch Long-Term Agreements included a description of the sector, an assessment of the plant's energy consumption in the base year, a survey of opportunities for energy-efficiency improvement, and a description of the monitoring and energy management techniques used (Nuijen, 2002). Identified energy-efficiency measures were grouped in five categories: good housekeeping/energy management, retrofit or strategic investments, energy-efficiency investments, cogeneration, and other measures (e.g. changes in feedstock). The individual enterprise audits were done by the company itself and/or by independent consultants. The results of the audits were reported to an independent government agency, and provided the basis for final discussions and negotiations between the industries and the government to establish the final target for the sector. The assessments were further used as a basis for the company Energy Savings Plan which included an assessment of energy consumption in the base year, a survey of opportunities for energy-efficiency improvement, monitoring and energy management, research and development of new energy-efficient technologies, and demonstration projects of energy-saving measures. 
Various support measures were implemented within the LTA1s, including free audits to identify opportunities for energy-efficiency improvement (Rietenbergen et al., 1998). During the period of the LTA1s, The Netherlands operated the Accelerated Depreciation on Environmental Investment program (VAMIL), which allowed an investor to more rapidly depreciate its investment in environmentally-friendly machinery, reducing operating profits and tax payments. This program started in 1991 and included equipment that reduces water use, soil and air pollution, noise emissions, waste production and energy use. To qualify, the equipment had to have relatively positive environmental impact, be not yet widely accepted in the country, have no negative side effects, and have the potential for a substantial market in the country. The list of qualifying equipment was updated regularly. Costs associated with obtaining advice on the purchased machinery were also subject to accelerated depreciation (IISD, 1994; SenterNovem, 2005a).

The Netherlands also established the Energy Investment Deduction (Energie Investeringsaftrek, EIA) program where originally $40 \%$ and up to $55 \%$ of the annual investment costs of energy-saving equipment could be deducted from the fiscal profit during the calendar year in which the equipment was procured, up to a maximum of $€ 107$ million. Qualifying equipment is provided on an "Energy List" and the costs associated with obtaining advice for purchased equipment could also be included. Approval was granted by SenterNovem, an agency under the Dutch Ministry of Economic Affairs. The budget for this program in 2005 was $€ 137 M$ (Aalbers et al., 2004; SenterNovem 2005b).

\section{Compliance}

There were no penalties for companies that did not meet their annual energy-saving targets. Instead, when such companies were identified through annual monitoring, they were provided with additional support from NOVEM regarding means to meet the targets. Companies that failed to provide an ECP and to report annual monitoring results could be dropped from the agreements at which point they were then subject to environmental permitting regulations that LTA1 companies are exempted from (Kerssemeeckers, 2002).

\section{Industry Participation}

In total, 29 agreements were signed involving about 1,250 establishments, accounting for energy consumption of 547 PJ annually and representing about $90 \%$ of industrial primary energy consumption in The Netherlands. The participating industries included those from base metals (iron/steel and non-ferrous), construction materials (asphalt, ceramics, cement, glass, bricks, and sandlime bricks), chemicals, light industry (iron foundries, cold storage and refrigeration, industrial laundries, surface treatment, and carpet), other industry (paper and paperboard, rubber and plastics, Philips Lighting, textiles), and the food and drinks industry (potato processing, breweries, cocoa, soft drinks, fruit and vegetable processing, coffee roasting, margarine/fats/oils, sugar, meat processing, and dairy) (SenterNovem, 2001). 
Drivers for industry to participate in the LTA1s included the cost savings that result from investments in energy efficiency measures; the ability of the companies to choose which measures to implement given the structure of the agreements where the government provides information and support to the companies but they determine the actual actions to be undertaken; considerations of sustainability, corporate social responsibility, and good housekeeping that are all part of international competitiveness; and the government assurance that there will be protection from new regulations directed towards energy efficiency for participating companies and an expedited environmental permitting process (Gerrits and Oudshoff, 2003).

\section{Energy Savings and GHG Emissions Reductions Savings Realized}

The LTA1 program ended in 2000 with an average improvement in energy efficiency of 22.3\% over the program period (see Figures 9 and 10) (Kerssemeeckers, 2002; MEA, 2001; Nuijen, 1998; Nuijen and Booij, 2002). This represents energy savings of 157 petajoules (PJ) and a reduction of $\mathrm{CO}_{2}$ emissions of $9 \mathrm{Mt}$ per year.

However, the $3 \%$ absolute $\mathrm{CO}_{2}$ emission reduction target outlined in the National Environmental Policy Plan was not met even though total emissions from the industrial sector returned to the 1990 level in 2000. Higher growth in industrial production during the program period is given as the reason for not meeting the absolute $\mathrm{CO}_{2}$ reduction target (Gerrits and Oudshoff, 2003). 
Figure 9. 2000 Target and Actual Energy Efficiency Improvement in Selected Industries in The Netherlands Compared to 1989 Baseline (\%).

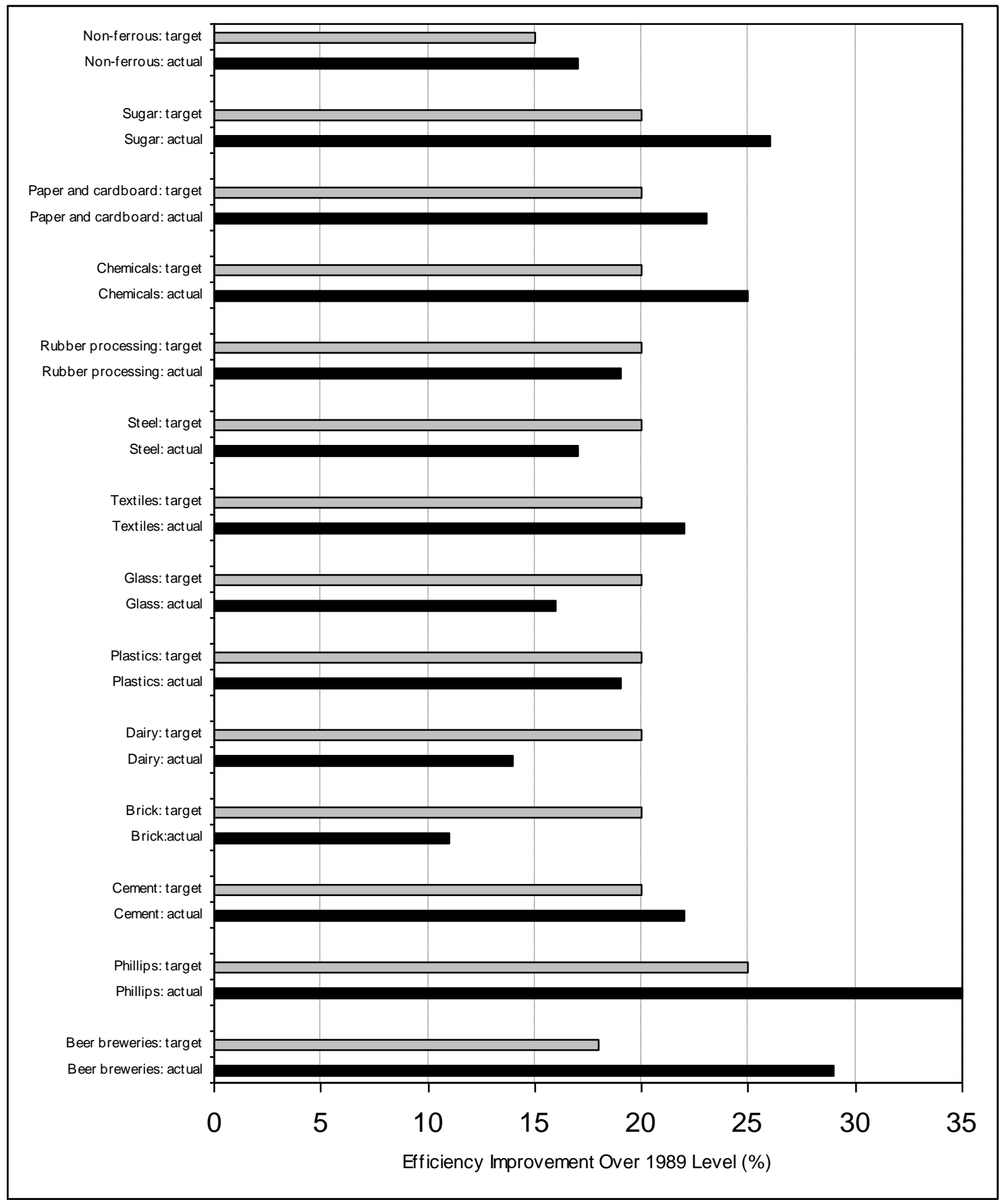

Source: Nuijen and Booij, 2002. 
Figure 10. Energy Efficiency Improvement Results of the Long-Term Agreements in The Netherlands, 1989-2000.

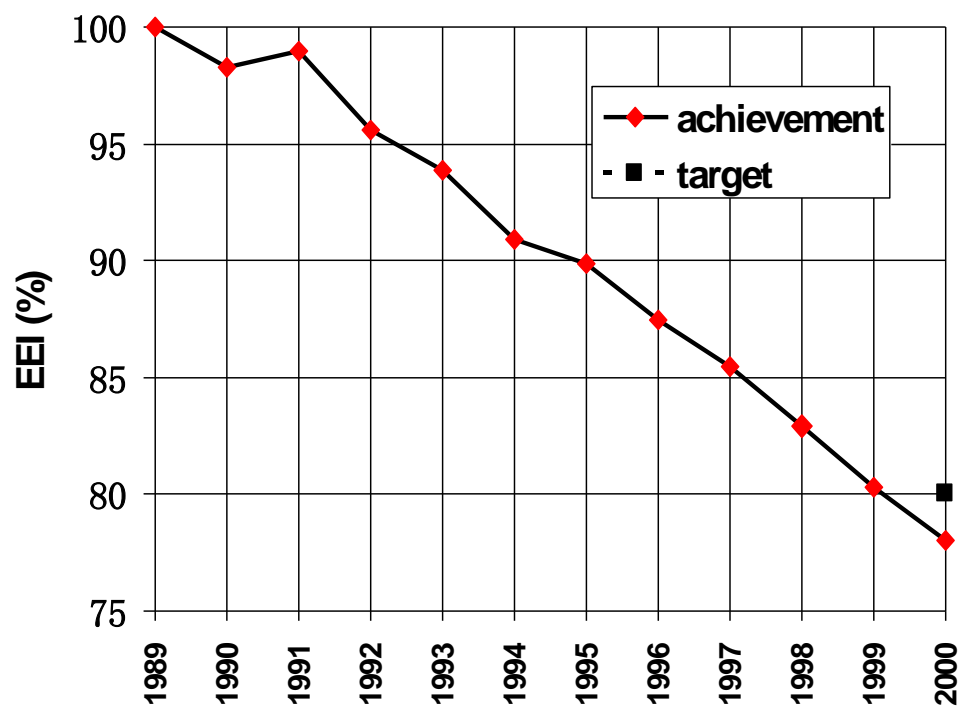

\section{Specific Actions Undertaken by Manufacturers}

A selected list of specific actions undertaken by the industry participants in the LTA1s includes the following measures. For other sectors and more details, see SenterNovem (2001) and Kerssemeeckers (2002). Based on the company ECPs and experience over the years, SenterNovem now has information on 2500 sector-specific and 800 generic measures for 35 industrial sectors (Vermeeren, 2008).

Steel industry

- The Dutch steel industry implemented 82 energy-saving projects between 1989 and 2000. These were in the areas of good housekeeping ( 30\%), investments in energysaving technologies ( $40 \%)$, retrofits ( $30 \%)$. Two of the most significant investments were the new oxygen plant at the Corus facility and the vacuum degasification unit at Nedstaal (Kerssemeeckers, 2002).

\section{Cement industry}

- Improvement of processes

- Optimization of input materials

- Optimization of a ball mill

- Optimization through dosing of clinker for a furnace

- Use of residual substances with a high caloric value as fuel substitutes

- Energy management

- Introduction of horizontal roller press systems for cement grinding

Non-ferrous industry

- Improved material efficiency 
- Improved capacity utilization

Pharmaceuticals industry

- Computer-driven energy monitoring system

Paper and Paperboard industry

- Integrated energy management system

- CHP

- Reduction of material losses during production

Asphalt industry

- Improved planning and coordination of production with processors

- Modernization through closing technologically outdated facilities

- Installation of a parallel drum so that $50 \%$ old asphalt can be added to new asphalt

- New storage silos with improved insulation

Glass industry

- Reduction of emissions and froth from glass furnaces

- Optimization of radiant heat transfer through coordination of flame emission spectra and improvement of flame cover

Sandlime brick industry

- Discontinuing heating of pressing tools when production is not in progress

- Optimization of pre-mixes

- Optimization of sawing processes

- Automatic sorting of elements

- Replacement of a degasser

- Automation of steam management (experienced some difficulties)

Chemicals industry

- Use of CHP

- Debottlenecking

- Increased production capacity

- Better use of production capacity

- Energy management

Cold storage and refrigeration

- New construction

- Repairs

- Extra insulation

- Automation of cooling unit control

- Optimizing condensation and condenser temperatures

- Application of hot gas thawing

- Conveyor belt with an air lock and small doors for the pallets to roll in and out 
Industrial laundries

- Gas finishers

- Replaced steam dryers by gas

- Dryers and filtration equipment

- Applied CHP

- Purchased flue gas condensers

- Hot rinsing

- Optimizing loads

Carpet industry

- Good housekeeping

- Optimizing spinning of fibers

- Backing for frequency regulators

- Changes in paint line working methods

- Optimizing process equipment

- Application of residual heat from compressors

- Savings on space heating through new construction

Paper and paperboard industry

- A Product and Energy Management System (PEMS) was developed and implemented

- CHP

- Optimal use of raw materials

Rubber and plastics industry

- Conservation projects involving investments in production assets, replacements and facilities

- Generation of compressed air

- Good housekeeping measures

Textile industry

- Redesign/optimization of production in connection with new construction

- Alternative reinforcement process

- Measures from the 'Broad Washing' user group

- Heat exchangers for broad bleaching

- Frequency regulators on spinning machines

- Energy and production management system for energy operations

- New dyeing unit with heat recovery

- Optimization of compressed air facility

- Frequency regulators on new production line

Breweries

- Recovery of heat from flue gases

- Optimization of the cooling unit

- Good housekeeping projects

- Peak-saving project 
Cocoa industry

- Improving capacity utilization

- Replacing two old production lines with one new one

- Process modification in butter deodorization

- Application of frequency regulators

- Good housekeeping measures

Fruit and vegetable processing

- Good housekeeping

- Replacement of a steam boiler

- Installation of a flue gas condenser with a steam boiler.

- Improved capacity utilization

Sugar industry

- Good housekeeping activities

- Minor changes in the production process

- Preparation for boiling with lower fumes

- Replacement of old vacuum pumps

Dairy industry

- Process automation

- Increased regenerative processes (heat recovery)

- Optimization of steam supplies

- Commissioning of new CHP unit

- Optimization of two existing CHP units

Oil refineries

- Strategic investment projects

- Commissioning of various new units that expanded secondary processing capacity,

\section{Assessment and Evaluation}

Evaluations of the LTA1 program found that the agreements helped industries to focus attention on energy efficiency and identify cost-effective options that met commonly used investment criteria (Korevaar et al., 1997). The energy savings from this program are the result of a comprehensive effort to increase implementation and development of energy-efficient practices and technologies in industry by removing or reducing barriers. This highlights the importance of offering a package of measures that includes financial, technical, and informational assistance instead of a set of individual measures. A review of the LTAs noted that in addition to the energy savings - and at least as important - the agreements "placed the issue of energy conservation on corporate agendas" (MEA, 2001).

A 2002 evaluation of the LTA1s found that $30 \%$ to $40 \%$ of the energy savings achieved during the program could be "considerable or entirely" stimulation by the signing of the LTAs. These savings were comprised of investments in the replacement of existing 
equipment (32\%), investments in retrofit measures (18\%), CHP investments (22\%), good housekeeping (9\%) and others non-categorized measures (22\%) (Kerssemeeckers, 2002).

A more recent evaluation calculated that the cost of the LTA1s was about $\$ 10$ per tonne of $\mathrm{CO}_{2}$ reduced (Blok et al., 2004).

\section{Long-Term Agreements - Second Phase (LTA2)}

Following the LTAs, the Dutch government established a second LTA program - referred to as the Long-Term Agreements 2 (LTA2) program - for smaller businesses and industry. The LTA2 program, which ran from 2001 to 2008, differed from the first LTAs in that the LTAs were a voluntary agreement between Ministries and sectors, while the LTA2s were an agreement between individual businesses, sectors, and competent authorities.

The LTA2s extended beyond the promotion of energy-efficiency to include "expansion themes" of renewable energy and energy-efficient product development. Companies can obtain credit for switching to any of the following renewable sources: wind energy; thermal, photovoltaic and passive solar energy; geothermal energy; hydro-electric power; heat/cold storage; heat pumps using ambient heat; energy generated from waste or biomass. Energy-efficient production development includes "adapting an old product or designing a new product with the aim of reducing energy consumption throughout the product life cycle" (Avest and Gerrits 2003; Gerrits and Oudshoff, 2003).

As part of the LTA2s, SenterNovem and representatives of the sector develop and maintain a "measurement list" of possible efficiency improvements that consists of a detailed description of the measure, investment costs, energy savings, returns on investment and if financial support is available for the measure. ${ }^{9}$

The LTA2s include guidance for establishing an Energy Management System based on the ISO 14001 standard for environmental management systems. ${ }^{10}$ Companies that joined the LTA2s had an obligation to implement an energy management system within two years. The requirements are explained and outlined in Structural Attention for Energy Efficiency by Energy Management, The Energy Management System Specification with Guidance for Use, and the Energy Management Checklist which provides a means to verify which requirements have been fulfilled and which require improvement (SenterNovem, 2004a; SenterNovem, 2004b; SenterNovem, 2004c). Of the companies that had participated for two years or more in $2008,95 \%$ had introduced an energy management system (SenterNovem, 2009).

A 2005 evaluation of the program indicated that 34 sectors were participating, representing a total of 906 companies. The industrial companies participating in this program achieved an energy efficiency improvement of $19.1 \%$ compared to 1998 (the

\footnotetext{
${ }^{9}$ To determine the return on investment (ROI), SenterNovem developed a tool to determine ROIs of measures. This Excel tool can be downloaded from: http://www.senternovem.nl/mmfiles/tvt ncw tcm24111964.xls (in Dutch).

${ }^{10}$ http://www.senternovem.nl/LTA/issues/energy management/index.asp
} 
reference year) (SenterNovem, 2006). The energy efficiency improvements made by these companies during the 2001-2004 period were equivalent to an emissions reduction of $2.8 \mathrm{MtCO}_{2}$ (SenterNovem, 2005c). At the end of the program, there were 950 participating companies, energy efficiency had improved by $23.2 \%$, and the average annual energy improvement was $2.4 \%$ (SenterNovem, 2009; Vermeeren, 2008).

\section{Benchmarking Covenants}

In addition to the LTA2 program, the Dutch government also established the Energy Benchmark Covenant program for large energy-intensive industries. ${ }^{11}$ Signatories to the covenant are the Ministry of Economic Affairs, the Ministry of Housing, Spatial Planning and the Environment, the Inter-Provincial Consultative Forum on behalf of the provinces, a national-level industrial and employer association and various industrial sectoral associations. Industrial companies must consume at least 0.5 PJs of energy per year to join the agreement. Industries pledge to be among the world's leaders in energy efficiency by 2012 at the latest. The government ensures that the participating industries are not subject to additional government policies regulating $\mathrm{CO}_{2}$ emissions reductions or energy conservation and that new energy taxes will not be levied on the participating industries. The participating industries establish an energy efficiency plan describing how they will meet their target. Six power generating companies and 97 industrial companies comprising a total of 232 facilities have signed the Benchmarking Covenant. These facilities have an aggregate energy consumption of 1,060 PJ and represent $94 \%$ of the industrial sector energy consumption and $100 \%$ of the electric sector energy consumption in the country (Commissie Benchmarking, 2002). Total expected savings from this program are $95 \mathrm{PJ}$ in 2012, avoiding approximately $5.8 \mathrm{MtCO}_{2}$ (Commissie Benchmarking 2004).

The Dutch Benchmarking Covenants, which began in 2001, used a benchmarking approach for target-setting. Using this approach, the participating company hires an expert third party to perform a study of the international best practice in terms of energy efficiency for all of its processing plants once every four years. On the basis of the information provided by the studies, the total target for energy efficiency improvements for the entire facility is determined using the weighted average of the calculated energy efficiency figures. The results of the international best practice benchmarking study are then sent to the independent authority which verifies the accuracy and completeness of the expert third party's methods and results of the study (Commissie Benchmarking, 1999).

For a number of reasons, including the conflicting requirements due to the regulation of many of the participating companies through the European Union Emissions Trading Scheme and a lack of performance, the Benchmarking Covenant program was abandoned in 2008 and the large energy users were ultimately re-united with the small and medium energy consumers in the subsequent program (LTA3s) (Gerrits, 2008; Kavelaars, 2008).

${ }^{11}$ http://www.benchmarking-energie.nl/ 


\section{Long-Term Agreements 3 (LTA3s)}

In 2008, the LTA2s and Benchmarking Covenants ended and the programs were combined into the third phase of the Long-Term Agreements (LTA3s) that will last from 2009 to 2010. As a result of the Dutch government's recently announced target to improve energy efficiency by $20 \%$ in 2020 compared to 2010 and the related goal of improving energy efficiency by $2 \%$ per year during this time period, the LTA companies are expected to strive for $2 \%$ reduction per year and if they cannot reach this goal, they must provide an explanation. There are 1100 companies in the LTA3s. The LTA3 sector organizations are being supported through funding and experts provided by SenterNovem to assist in the development of long-term roadmaps that address actions in the areas of energy efficiency, product supply chain, and product lifecycle. The vision of the program is to reduce energy consumption by $50 \%$ by 2030 (Vermeeren, 2008; Gerrits, 2008; Kavelaars, 2008). 


\subsubsection{Denmark - Voluntary Agreement within GHG Tax Program}

In 1990, the Danish government set a goal of reducing $\mathrm{CO}_{2}$ emissions by $20 \%$ in 2005 compared to 1988 levels. This goal was established following the Toronto Conference on The Changing Atmosphere in 1988, which is based on a report of United Nations World Commission on the Environment and Development, and was aimed at issues of global environment and sustainable development (DME, 1990). In addition, under the Kyoto Protocol and the following EU burden-sharing agreement, Denmark is also obligated to reduce GHG emissions by $21 \%$ compared to 1990 emission levels by 2008-2012.

In support of the national $\mathrm{CO}_{2}$ reduction target, a $\mathrm{CO}_{2}$ tax was introduced in Denmark on May 15, 1992 for households and January 1, 1993 for industry. The purpose of the tax was to address environmental protection issues as well to cover fiscal gaps and support a growing national economy by redirecting the tax revenues to the economy. All fossilfuel burning households were required to pay $€ 13.4$ per ton $\mathrm{CO}_{2}\left(\$ 18.8 \mathrm{USD} /\right.$ ton $\left.\mathrm{CO}_{2}\right){ }^{12}$ However, value-added tax (VAT)-registered businesses were only required to pay $€ 6.7$ per ton $\mathrm{CO}_{2}$ (\$9.4 USD/ton $\mathrm{CO}_{2}$ ) (Svenden, 1997), to address concerns over international competitiveness and domestic employment.

In 1996, the Danish government established the Green Tax Package, which included an additional $\mathrm{CO}_{2}$ tax, a new $\mathrm{SO}_{2}$ tax and new energy taxes on space heating. While the standard $\mathrm{CO}_{2}$ tax rate was kept unchanged, the tax base of the regular energy taxes was extended to cover what was defined as the business use of "space heating", the $\mathrm{CO}_{2} \operatorname{tax}$ reimbursement scheme was rearranged and tightened (Price, et al., 2005). Heavy processes are defined as energy-intensive processes. Light processes include energy consumption that is neither heavy processes nor space heating. The Danish $\mathrm{CO}_{2} \operatorname{tax}$ system has five levels, as displayed in Table 7.

Table 7. 1996-2002 Danish $\mathrm{CO}_{2}$ Tax for Industry (in Euro per ton of $\mathrm{CO}_{2}$ )

\begin{tabular}{|l|c|c|c|c|c|c|c|}
\hline Year & $\mathbf{1 9 9 6}$ & $\mathbf{1 9 9 7}$ & $\mathbf{1 9 9 8}$ & $\mathbf{1 9 9 9}$ & $\mathbf{2 0 0 0}$ & $\mathbf{2 0 0 1}$ & $\mathbf{2 0 0 2}$ \\
\hline Space heating, no agreement & 13.4 & 13.4 & 13.4 & 13.4 & 13.4 & 13.4 & 13.4 \\
\hline Space heating, with agreement & 13.4 & 13.4 & 13.4 & 13.4 & 13.4 & 13.4 & 10.5 \\
\hline Light process, no agreement & 6.7 & 8.0 & 9.4 & 10.7 & 12.1 & 12.1 & 12.1 \\
\hline Light process, with agreement & 6.7 & 6.7 & 6.7 & 7.8 & 9.1 & 9.1 & 9.1 \\
\hline Heavy process, no agreement & 0.7 & 1.3 & 2.0 & 2.7 & 3.4 & 3.4 & 3.4 \\
\hline Heavy process with agreement & 0.4 & 0.4 & 0.4 & 0.4 & 0.4 & 0.4 & 0.4 \\
\hline
\end{tabular}

Source: DEA, 2005; Ericsson, 2006.

The energy tax was imposed on energy consumption used for ordinary space heating including hot water. During 1996-1998, the energy tax was about €5.5 per GJ (\$8.1 USD/GJ). After 1998, the level of energy tax was included to about $€ 6.8$ per GJ (\$10 USD/GJ) (DEA, 2005; DEA, 2000). $\mathrm{SO}_{2}$ tax was gradually introduced since 1996. Currently, it is $€ 1.34$ ( $\$ 1.88$ USD) per kilo of emitted $\mathrm{SO}_{2}$, or $€ 2.68$ ( $\$ 3.75$ USD) per kilo of sulfur in the fuel. The total Danish Green Tax for different energy source and energy use in 2000

12 1Euro=1.4 USD. 
is shown in Table 8. Similar to previous taxation, revenues from the Green Tax Package were used to lower tax on labor and income, subsidize energy-efficient measures, and provide special subsidize for small companies (DEA, 2005).

Table 8. Energy, $\mathrm{SO}_{2}$, and $\mathrm{CO}_{2}$ Taxes for Different Energy Sources and Uses

\begin{tabular}{|l|l|c|c|c|c|}
\hline $\begin{array}{l}\text { Energy } \\
\text { Source }\end{array}$ & Unit & $\begin{array}{c}\text { Heavy Process, } \\
\text { No Agreement }\end{array}$ & $\begin{array}{c}\text { Light Process, } \\
\text { No Agreement }\end{array}$ & $\begin{array}{c}\text { Space } \\
\text { Heating }\end{array}$ & $\begin{array}{c}\text { Sulfur } \\
\text { Content }\end{array}$ \\
\hline Electricity & Euro/MWh & 5 & 14 & 87 & \\
\hline Natural gas & Euro $/ 1000 \mathrm{~m}^{3}$ & 7 & 27 & 244 & 0 \\
\hline Gas oil & Euro $/ \mathrm{m}^{3}$ & 10 & 34 & 269 & 0.1 \\
\hline Fuel oil & Euro/t & 21 & 49 & 315 & 0.5 \\
\hline Coal & Euro/t & 22 & 43 & 221 & 0.6 \\
\hline
\end{tabular}

Source: DEA, 2005.

In order to encourage large energy-consuming companies to improve energy efficiency as well as to ensure their international competitiveness, the Danish Voluntary Agreement on Industrial Energy Efficiency (DAIEE) was launched in January 1996.

\section{Program Design}

Structure

The Danish Energy Authority (DEA) and the Central Customs and Tax Administration (CCTA) are the two main agencies in charge of the DAIEE program. The DEA manages the voluntary program directly, including informing companies about the scheme, receiving and approving applications, negotiating voluntary agreements with companies, and signing agreements. The DEA initially was also responsible for monitoring companies performance, but later in the revised program monitoring was handled by "accredited organizations that certify the energy management systems" (Ericsson, 2006).

The CCTA is responsible for $\mathrm{CO}_{2}$ tax rebates to the companies. The CCTA can readjust companies' tax rebates according to the voluntary agreements signed between companies and the DEA. Figure 11 shows the organization of the program.

Figure 11. Organization of the DAIEE Scheme

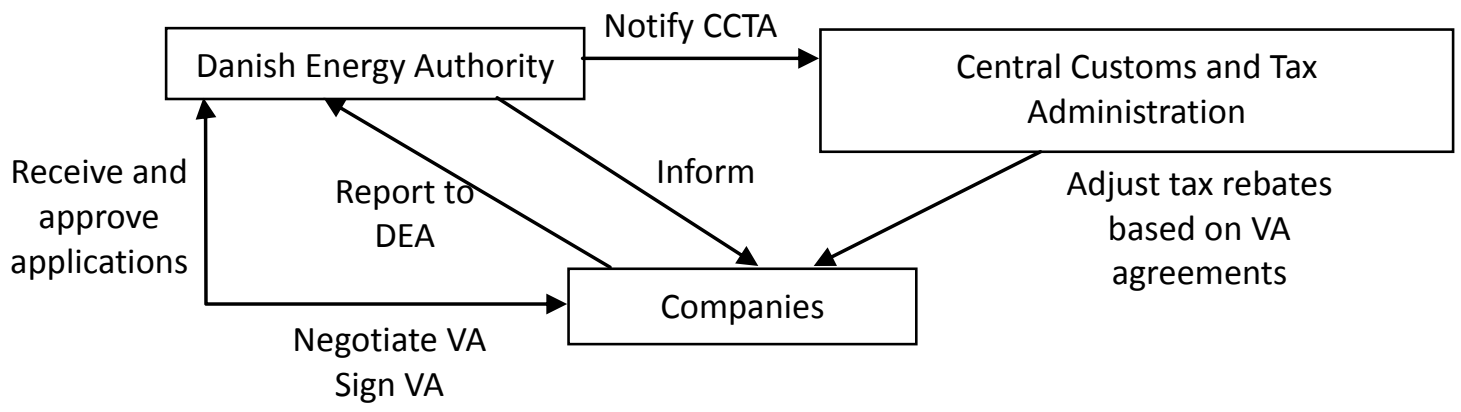

Although no specific $\mathrm{CO}_{2}$ emissions reduction target was set at that time, it was later estimated that the agreements would reduce overall $\mathrm{CO}_{2}$ emissions in Denmark by $0.6 \%$, 
or $0.4 \mathrm{MtCO}_{2}$ per year by 2005 compared to the 1988 level (Finansministeriet et al. 1999).

\section{Commitments and Benefits}

Companies or associations who joined the program signed 3-year agreements with the Danish Energy Authority (DEA) and had a close dialogue with other interested parties as well, such as the Confederation of Danish Industries (DEA, 2005). The signed voluntary agreements, which were based on estimates of a company's production potential and estimated investments, could be renegotiated during the three-year agreement time if the original estimates change considerably (DEA, 2001). To reduce administrative costs, companies in the same sector could sign a collective agreement with the DEA; however, each company still needed to sign an individual agreement within the industry association.

Companies who joined the DAIEE scheme could obtain $\mathrm{CO}_{2}$ tax rebates. For instance, in 2002, a heavy process company with a voluntary agreement with the DEA only paid $3 \%$ of the standard tax (i.e., $€ 0.4 / \mathrm{t} \mathrm{CO}_{2}$ or $\$ 0.6 \mathrm{USD} / \mathrm{t} \mathrm{CO}_{2}$ ), while a heavy process without signing agreement had to pay $25 \%$ of the tax rate (i.e., $€ 3.4 / \mathrm{tCO}_{2}$ or $\$ 4.8 \mathrm{USD} / \mathrm{t} \mathrm{CO}_{2}$ ).

Each agreement had four main elements: energy audits, special investigations, energy management, and investments in energy efficiency.

During the first agreement period, from 1996 to 1999, participating companies were required to undertake energy audits and establish energy action plans in collaboration with the DEA. Energy audits had to be conducted by an independent auditor authorized by the DEA. The costs of the energy audits were paid by the companies, who could apply for subsidies to cover half of the costs. Companies were also required to carry out special investigations that are focusing on specific areas of their primary processes. Typically, one agreement would include two to five special investigations. After identifying the issues and energy-saving opportunities, companies were committed to implement all "profitable" energy saving measures with a payback period up to four years.

Companies were also required to introduce energy management by adopting the Danish Standard on Energy Management DS2403. The standard includes procedures for energyefficient design, monitoring and control of energy consumption, technical information and awareness of employees.

In addition, companies needed to motivate staff to ensure new investments in equipment would be for energy-efficient projects. Subsidies for investments on energy efficiency were provided for up to $30-50 \%$ of the costs (Bjørner and Jensen 2000; Johannsen, 2002).

When the DAIEE program moved to the second (2000-2002) and third stage (2003 onward), energy audits were no longer mandatory, but companies were still required to establish energy action plans based on their own energy management systems. Since 
2003, the energy management systems of companies had to be certified by DANAK, the Danish Accredition Scheme (Krarup and Millock, 2006). Annual reports on companies' performance as well as reports on the special investigations were required to be submitted to the DEA.

\section{Compliance}

If a company failed to meet its commitments, the agreement was rescinded and the company had to pay full energy and $\mathrm{CO}_{2}$ taxes. Previously received tax refunds by the company were required to be returned (DEA, 2001). However, there were only a few cases where the DEA cancelled agreements with companies (Ericsson, 2006).

Besides imposing a high $\mathrm{CO}_{2}$ tax if the targets are not met, a series of strict control measures were also put into place (Klok, 2002). For example, companies are required to submit an annual compliance report, which includes its progress and reports on special investigations, to the DEA (DEA, 2001) for monitoring and verification.

\section{Industry Participation}

The target of the DAIEE is high energy-consuming companies. Companies with heavy processes, such as greenhouse heating, production of foodstuffs, sugar, paper, cement and glass are eligible to join the voluntary agreements. Companies with light processes can also join the program if the company's tax on energy use exceeds $4 \%$ of the company's value-added (DEA, 2001).

Between 1996 and 2001, approximately 300 companies entered into agreements with the Danish Energy Agency, representing $60 \%$ of total industrial energy consumption in Denmark (Hansen, 2001). The energy use covered by the agreements was estimated to be 77 PJ for 2005 (Ericsson, 2006). Table 9 shows the number of companies that signed an agreement by type of agreement and by industrial sub-sector.

Table 9. Number of Companies with Individual and Collective Agreements

\begin{tabular}{|l|c|c|c|c|c|}
\hline & $\mathbf{1 9 9 6}$ & $\mathbf{1 9 9 7}$ & $\mathbf{1 9 9 8}$ & $\mathbf{2 0 0 0}$ & $\mathbf{2 0 0 5}$ \\
\hline Individual & 30 & 76 & 101 & 88 & 78 \\
Collective & 39 & 90 & 129 & 241 & 202 \\
Greenhouses & 39 & 81 & 99 & 215 & 180 \\
Milk condensing & 0 & 9 & 9 & 3 & 3 \\
Brickyards & 0 & 0 & 21 & 19 & 16 \\
Potato industry & 0 & & & 4 & 3 \\
\hline Total & 69 & 166 & 230 & 329 & 280 \\
\hline
\end{tabular}

Source: Ericsson, 2006; DEA 2000.

Companies that signed an agreement through a collective arrangement represent more than two thirds of the companies. Greenhouses represented by far the largest sub-sector. A large number of the companies also belong to the food industry. It is worth noting that there are few energy-intensive industries in Denmark. The participating companies included only a small number of cement and paper plants. 


\section{Energy Savings and GHG Emissions Reductions Realized}

An assessment in 1999 found that the voluntary agreements saw a reduction in energy consumption of 2 to $4 \%$ of total energy consumption per agreement after three years (exceeding business-as-usual by about 1\% per year) (Togeby et al., 1999). Other studies have found that the scheme "creates a substantial environmental effect in an economically efficient way" (Finansministeriet, 1999) and that energy consumption levels have declined by $10 \%, 9 \%$ of which is attributed to the energy efficiency agreements (Bjørner and Jensen 2000).

Based on an interview survey one year after 150 firms entered in agreements, Togeby et al. (1998) estimated that about $66 \%$ of the energy savings realized were implemented due to the agreements. Interestingly, they also found that in many cases energy audits were only summarizing existing knowledge rather than helping to find new opportunities to save energy. Nevertheless they also found that agreements were generally received positively by energy managers that felt that their role in the company had been enhanced due to the agreements.

DEA evaluations found that the agreements reduced energy use in the participating companies. Overall, it is estimated that the agreements resulted in $\mathrm{CO}_{2}$ emissions reduction of $6 \%$ in participating companies for $1996-2005$, resulting in $0.4 \mathrm{MtCO}_{2}$ emissions reductions, of which $60 \%$ is due to the implementation and maintenance of Energy Management System (EMS). Thus, the agreements were estimated to have improved overall energy efficiency by about $0.7 \%$ per year (Ericsson, 2006). Table 10 shows the estimated contribution of the Green Tax Package to the goal of reducing the 1988 emission level by $20 \%$ (DEA, 2005). In 2005, $\mathrm{CO}_{2}$ emissions reductions are estimated to be $3.8 \%$, corresponding to $2.3 \mathrm{MtCO}_{2}$. Half of these reductions were due to the taxes themselves, the rest to the subsidy and agreement scheme.

Table 10. Total $\mathrm{CO}_{2}$ Emission Reduction Estimates in 2005

\begin{tabular}{|l|c|c|}
\hline & $\begin{array}{c}\text { Share } \\
\mathbf{( \% )}\end{array}$ & $\begin{array}{c}\text { CO2 Emissions } \\
\text { Reduced (Mt) }\end{array}$ \\
\hline Taxes & $2.0 \%$ & 1.2 \\
\hline Subsidies & $1.2 \%$ & 0.7 \\
\hline Agreements & $0.6 \%$ & 0.4 \\
\hline Total & $\mathbf{3 . 8 \%}$ & $\mathbf{2 . 3}$ \\
\hline
\end{tabular}

Source: DEA, 2005.

\section{Specific Actions Undertaken by Manufacturers}

The key factor to the successful implementation of the agreements in Denmark was the requirement for each company to establish an EMS. According to DEA (2002) typical savings of at least $10 \%$ to $15 \%$ are observed during the first years of implementation of the EMS. In 2001, Denmark developed an energy management standard, DS 2403. Its structure and terminologies are similar to other standards, such as the environmental 
management system (ISI 14001) and those for the quality management system (ISO 9001). This explained in part its successful adoption by companies. According to Ericsson (2006), many companies considered the EMS to be very helpful in reducing energy consumption and would keep this system if they no longer were committed to an agreement. Numerous companies that were part of the agreement program have also implemented the EMS. However, it must be noted that smaller companies find the administration of the EMS somewhat burdensome as the typical cost for verifying the EMS is in the range of $€ 1,300-€ 10,700$ (US $\$ 1,800$ to $\$ 15,000$ ) (Ericsson 2006). It is estimated that about $60 \%$ of the emissions reductions from the agreements were due to the implementation and maintenance of an EMS. According to Ericsson (2006), the EMS was cautiously estimated to improve energy efficiency by $0.44 \%$ per year in the evaluation in 1998 and by $0.4 \%$ in the evaluation in 2000 .

Energy management is a method to secure a continuous energy efficiency improvement. It consists of five distinctive steps, as shown in Figure 12, each containing a number of smaller steps. This first step directs top management to prepare an energy policy that sets the overall guidelines. The second step establishes the action plan by examining energy use in the company, determining the order of priority of the energy saving efforts and setting target in concordance with the overall guidelines. The third step consists of the implementation of the action plan by involving employees so that energy efficiency becomes a priority in every aspect of the operation of the company. The fourth step concerns monitoring and evaluation, as well as the possible corrective and preventive actions in case of non-conformance. Finally the last step is the review and assessment from top management of the elements of the energy management system and their possible modification if needed. The EMS process is then repeated.

Figure 12. Five Steps for Energy Management

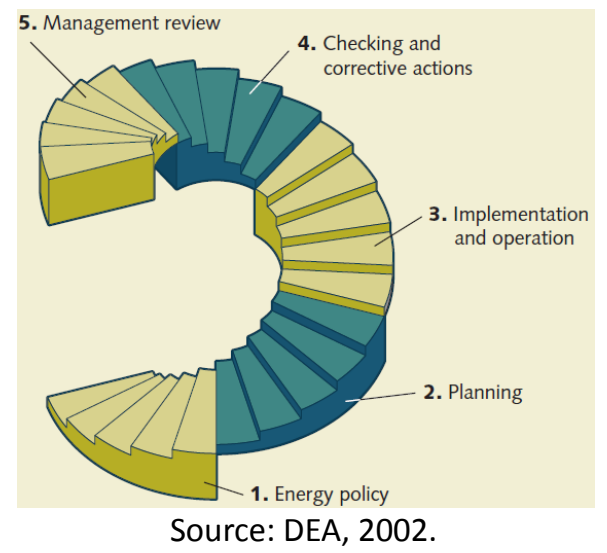

\section{Assessments and Evaluations}

Most evaluations carried out on the Danish scheme are rather qualitative or concern only a limited number of companies. This stems from the fact that agreements themselves are qualitative and do not include quantitative targets. Moreover the terms of the agreement have been kept confidential, making their assessment by a third party 
difficult. However, Denmark is the only country that has attempted to evaluate the net effect of the agreement scheme (Rezessy, et al. 2005).

In addition, qualitative evaluations have found that while most of the energy-efficiency measures would have been implemented in the facilities eventually, the tax scheme and associated agreements accelerated their implementation (Price et al., 2005; Krarup et al. 1997). According to Krarup and Millock (2006), agreements have impelled firms to implement energy efficiency investments with payback periods longer than what was current practice. Firms usually accept a payback period of one to two years for energy efficiency investments, while with the agreements scheme firms were required to implement projects with a payback period of four to six years before 2000 and less than four years after 2000 .

Among the main concerns related to the implementation of the agreements in Denmark was the relatively high administrative cost for the firms and the government. The cost for the firms included the energy audit and verification process which was estimated to be between EUR 17,000 and 56,000 (US $\$ 24,000$ to 79,000 ). ${ }^{13}$ In 2000 , the obligation of an energy audit was removed to reduce the burden on firms. The cost pertaining to the government also diminished in 2001 with the introduction of the EMS. The main reason is that the monitoring was then transferred to the accredited organizations that certify the EMS. Administration costs also diminished since the process became more systematized and the proportion of agreement renewals increased as the program continued, which reduced the amount of workload. Consequently, The DEA's administrative costs for 2006 were estimated to be roughly $270,000 €$ (US $\$ 380,000$ ) including 3 employees, compared to roughly 2.7 million $€$ (US \$3.8M) including up to 31 employees in 1996 (Ericsson 2006).

DEA has been struggling to gather useful data to conduct evaluations. Companies are required to submit data through questionnaires but the data was found to be of rather poor quality. In many cases information was missing or incorrect. This database was therefore not used in the evaluation, which instead was based on interviews.

Agreements with the involvement of industrial associations have generally a positive impact on the development and diffusion of knowledge and new technology energy improvement. Moreover, the cost efficiency is better for the collective agreements than the individual agreements and are encouraged by the DEA.

${ }^{13} 1.40$ US \$/EUR 


\subsubsection{UK - Voluntary Agreement within GHG Tax Program}

The UK Climate Change Program was established in 2000 to meet both the country's Kyoto Protocol commitment of a $12.5 \%$ reduction in GHG emissions by 2008-2012 relative to 1990 and the domestic goal of a $20 \% \mathrm{CO}_{2}$ emissions reduction relative to 1990 by 2010 (DEFRA, 2006). A key element of the Climate Change Program is the Climate Change Levy, a tax on the use of energy (natural gas, coal, liquefied petroleum gas, and electricity) applied to industry, commerce, agriculture, and the public sector. The revenues from the levy are returned to the taxed sectors through a reduction in the rate of employer's National Insurance Contributions and used to fund programs that provide financial incentives for adoption of energy efficiency and renewable energy (DEFRA, 2004).

\section{Program Design}

Structure

Through participation in Climate Change Agreements (CCAs), energy-intensive industrial sectors established energy-efficiency improvement targets. Companies that meet their agreed-upon target are given an $80 \%$ discount from the Climate Change Levy. The CCAs were originally negotiated and managed by the Department of Environment, Food, and Rural Affairs (DEFRA). In October 2008, oversight of the CCAs was moved to the newlyformed Department of Energy and Climate Change (DECC).

The process for setting the CCA targets began with information-gathering on the part of the government. The government obtained information regarding energy efficiency potential in energy-intensive industries through the Energy Efficiency Best Practices Program which produced good practice guides and case studies, new practice case studies, and information on future practices (Shock, 2000) as well as through a report prepared by ETSU (now AEA Energy \& Environment) on projections of industrial sector $\mathrm{CO} 2$ emissions under a business-as-usual scenario as well as two scenarios that included all cost-effective and all technically-possible technologies (ETSU, 1999). Then, for the ten largest energy-consuming sectors, individual companies made estimates of what energy efficiency improvements they could make based on an assessment of their potential and provided this information to their trade associations. The starting point for the major industries was studies establishing what would be expected under business-as-usual and what could be achieved if all cost-effective measures were adopted, which was based on recent history of efficiency measures, rates of technology uptake, expected growth rates, and investment plans.

Once this information was gathered, negotiations took place with each sector. The sector offered a target for the whole sector to the government. Negotiation then drew the process forward, with government often requiring the industry sector to improve their offer to a more challenging level, based on information on cost effective processes and general standards of energy management in the sector (Price, Blok, et al., 2005). 
The CCAs are comprised of "umbrella agreements" between DECC and the sector or trade associations and individual, or underlying, agreements between DECC and the companies. The umbrella agreements outline the sector targets, the commitments of the government and the sector, and the administrative processes. The individual agreements outline facility-level targets and commitments, government commitments, and the administrative processes.

\section{Commitments and Benefits}

The original goal of the CCAs was to reduce $\mathrm{CO}_{2}$ emissions $9.2 \mathrm{MtCO}_{2}$ by 2010 , which is ten times the estimated savings from the Climate Change Levy without the agreements (Pender, 2004). Due to target revisions and other changes, the goal was revised and it is now expected that the CCAs will result in savings of $6.9 \mathrm{MtCO}_{2}$ by 2010 (NAO, 2007).

Companies may choose to use either a relative target (energy per unit of production) or an absolute target (reduction of energy use). The majority of targets in the CCAs are relative targets. Targets can be adjusted to account for companies or units that enter or exit the association agreement, emissions trading, and product mix changes. Companies are required to report their progress every 2 years. The reporting requirements for each target unit include the total number of units of primary energy used during the target period for each type of fuel, the total number of units of carbon emitted from the target unit during the target period, the production throughput during the target period, and the information needed to calculate adjustments for product mix or emissions trading (if applicable).

Progress reports must be supported by information on how the calculations were made using spreadsheets supplied by the government. DEFRA, and now DECC, provides detailed guidance, including spreadsheets, on numerous topics such as (DECC, 2009):

- Guidance on eligibility

- Procedures for entrants and exits

- Calculating trading group targets

- Measuring energy consumption

- Accounting For renewable

- Guidance note on CHP

- Climate Change Agreements and emissions trading

- Handling structural change

Verification of the company reports is based on sample audits by an independent agency (paid for by the government); full verification of all results is not undertaken in order to minimize costs. Data on progress towards sector targets is also collected from member companies and reported by the sector associations. Sector associations must demonstrate to the auditors that they have maintained the accuracy of the data obtained from operators and that they have a system in place to ensure its continuing accuracy. 
Benefits to companies that participate in the CCAs include the services of the Carbon Trust, the UK Enhanced Capital Allowance Scheme, the ability to participate in the UK's domestic emissions trading scheme, and a "light touch" on energy efficiency regulation.

The UK's Carbon Trust is an independent entity that assists businesses and the public sector to reduce carbon emissions by $60 \%$ by 2050 (UK DTI, 2003). The Carbon Trust, which is funded from the proceeds of the Climate Change Levy, identifies carbon emissions reduction opportunities, provides resources and tools, provides interest-free loans to small- and medium-sized enterprises, funds a local authority energy financing scheme, promotes the government's Enhanced Capital Allowance Scheme, and has a venture capital team that invests in early-stage carbon reduction technologies as well as management teams that can deliver low carbon technologies (Carbon Trust, 2008).

The UK's Enhanced Capital Allowance Scheme allows a business to claim 100\% first-year tax relief on their spending on qualifying energy-saving technologies specified in the "Energy Technology List" on their income or corporation tax return. Businesses can write off the entire capital cost of their investments in energy-saving technologies against their taxable profits for the year during which they make the investment (HM Revenue \& Customs, n.d.). The technologies that currently appear on the 2004 Energy Technology List are: air-to-air energy recovery, automatic monitoring and targeting, boilers, combined heat and power (CHP), compact heat exchangers, compressed air equipment, heat pumps for space heating, HVAC zone controls, lighting, motors, pipework insulation, refrigeration equipment, solar thermal systems, thermal screens, variable speed drives, and warm air and radiant heaters (Carbon Trust, 2005).

Companies that exceed their targets will have excess carbon allowances which they are allowed to trade with companies that do not meet their targets through the UK Emissions Trading Scheme (DEFRA, 2005a). The carbon can also be banked for future periods.

Finally, CCA companies are provided a "Light Touch" on energy efficiency regulation which means that facilities that meet their CCA targets are deemed to have met the European Union Integrated Pollution Prevention and Control (IPPC) permit conditions. As such, these facilities need only to report basic energy use data and an energy plan to comply with the EU Directive.

\section{Compliance}

If company does not enter into a CCA or if a company within an agreement does not reach its target, then the full $100 \%$ of the energy tax must be paid. CCA companies that do not meet their targets can purchase carbon allowances. During the first and second assessment periods, carbon credits of $1.5 \mathrm{MtCO}_{2}$ were purchased and carbon credits of 2.6 $\mathrm{MtCO}_{2}$ were purchased to meet the third assessment period targets. During the same time periods, $8.8 \mathrm{MtCO}_{2}$ and $3.7 \mathrm{MtCO}_{2}$, respectively, were saved for future use (NAO, 2007). 


\section{Industry Participation}

Initially, there were 44 sector agreements representing about 5,000 companies and 10,000 facilities in the CCAs. Three sectors withdrew, an additional 12 sectors signed agreements, and two sectors merged, resulting in a current total of 52 sectors (AEA Energy \& Environment, 2009). The CCAs cover approximately $90 \%$ of industrial emissions in the UK.

\section{Energy Savings and GHG Emissions Reductions Savings Realized}

Table 11 shows that during the first target period (2001-2002) total realized reductions were nearly three times higher than the target for that period (Future Energy Solutions, AEA Technology, 2004). Sectors did better than expected because industry underestimated what they could achieve via energy efficiency. When negotiating the targets, most companies believed that they were already energy-efficient, but when they actually managed energy because of the CCA targets, companies saved more than they thought that they could, especially through improved energy management (Pender, 2004). Industry realized total reductions that were more than double the target set by the government during the second target period and that were nearly double the target during the third and fourth target periods (DEFRA, 2005b; Future Energy Solutions, AEA Technology, 2005; DEFRA, 2007; AEA Energy \& Environment, 2009).

Table 11. Results of the UK Climate Change Agreements: Periods 1-4

\begin{tabular}{|l|c|c|c|}
\hline Absolute Savings from Baseline & $\begin{array}{c}\text { Actual } \\
\text { (MtCO } / \text { year) }\end{array}$ & $\begin{array}{c}\text { Target } \\
\text { (MtCO }_{2} / \text { year) }\end{array}$ & $\begin{array}{c}\text { Actual minus } \\
\text { Target } \\
\text { (MtCO }_{2} / \text { year }\end{array}$ \\
\hline Target Period 1 (2001-2002) & 16.4 & 6.0 & 10.4 \\
\hline Target Period 2 (2003-2004) & 14.4 & 5.5 & 8.9 \\
\hline Target Period 3 (2005-2006) & 16.4 & 9.1 & 7.3 \\
\hline Target Period 4 (2007-2008) & 20.3 & 11.1 & 9.2 \\
\hline
\end{tabular}

Source: AEA Energy \& Environment, 2009.

\section{Specific Actions Undertaken by Manufacturers}

A comprehensive list of actions undertaken by manufacturers participating in the CCAs is not available. Some industrial associations have set up information exchange platforms so that members of their industry can share their experiences with energy efficiency. For example, the National Microelectronics Institute (NMI) conducts a Utilities Best Practice Forum where members share information and best practices. NMI notes that the forums are "extremely open, with members willingly sharing information on successful projects and techniques" (NMI, 2009).

\section{Assessment and Evaluation}

In 2007, the UK's National Audit Office reviewed the Climate Change Levy and CCAs and found that the agreements, along with the monitoring schemes, raised awareness of the potential for energy efficiency within the participating sectors. The review found that in general the benefits of the CCAs outweighed the program administrative costs. The report further found that the agreements "raised the profile of energy efficiency within 
businesses," "enabled businesses to achieve energy efficiency improvements," and that the early overachievement against the targets was due to a combination of significant energy efficiency investments and targets that could have been more challenging. The report also noted that "business opinion is divided over the effectiveness of the Agreements" (NAO, 2007). UK Steel stated that "these agreements have done more to increase awareness of energy efficiency across industry than any other government scheme" (UK Steel, 2007). The Food and Drink Federation noted that "in our view the CCAs have introduced a very well balanced 'carrot and stick' approach to improving energy efficiency and delivering carbon emissions reductions that the CCL 'stick' alone would not have delivered...The effect...has been to make participants focus on energy and emissions reductions at senior management levels; provide a framework to think about, develop and deliver energy savings programmes; provide robust and ongoing energy and emissions data to allow progress to be assessed and monitored, and; created much greater awareness of support mechanisms that help them to achieve their targets and deliver emissions reductions. Very importantly, CCAs have also reinforced business and competitive benefits through lower energy bills" (Food and Drink Federation, 2007).

An independent evaluation of the UK Climate Change Agreement (CCA) program found that in addition to the energy and GHG emissions reductions, the program provided "positive macroeconomic effects in economic terms, with small increases in GDP and employment, and negligible changes in general inflation" (Barker et al., 2007). The authors concluded that:

"Our assessment supports the argument that industries can make cost-effective energy-efficiency improvements by overcoming market failures and barriers when given incentives to do so. Such policy incentives are an important part of climate change policies, particularly in the UK and other European countries. However, national policy-makers and regulators are often reluctant to press industries to achieve significant energy-efficiency improvements because of fears that these will lead to higher costs and negative impacts on international competitiveness. As the UK CCAs demonstrate, a well-designed scheme with negotiated targets for energy-efficiency improvements may actually overachieve the targets because of an 'awareness effect' arising from the resulting focusing of attention on the potential for cost-effective improvements. Our findings suggest that, not only would stronger targets for energy-efficiency improvements be likely to lead to significant reductions in final energy demand and $\mathrm{CO}_{2}$ emissions, but that these would also lead to economic benefits to the national economy as a whole, partly through improvements in international competitiveness."

Finally, a 2008 report by the Environmental Audit Committee of the UK House of Commons found that businesses that signed the CCAs believe that they are more effective than the Levy. The report notes that it is extremely difficult to evaluate the results of the CCAs due to the different baseline years represented in the many agreements. The report notes that "anecdotal evidence suggest that the process of complying with CCAs has galvanized business interest in finding energy savings and that 
the key to this has been the incentive of the tax discount they offer." Finally, the report states that (House of Commons, Environmental Audit Committee, 2008):

"According to economic theory, businesses should have acted rationally by seeking to reduce their costs through increased energy efficiency. In practice, they appear to have needed an extra stimulus to change their approach to energy use. This has profound implications for climate change policy more widely. If even large corporations require additional policies to drive behavioural change, this must be all the more true for small businesses, public bodies, and private households." 


\section{Findings and Recommendations}

In general, the surveyed countries that have national-level policies aimed at the reduction of GHG emissions all developed comprehensive programs to engage the industrial sector in identifying and implementing energy efficiency and GHG emission reduction technologies and measures. The programs in the five countries that were reviewed in this report represent a variety of approaches to stimulate and maintain participation by industry.

Even though the approaches differed by country and each country engaged a diverse range of industrial sub-sectors, the results of most of these programs were impressive. The Large Industry Energy Network (LIEN) program in Ireland has documented an average annual energy savings of 3\% since 1995 and the newer, more stringent Energy Agreement Program (EAP) resulted in energy savings of $8 \%$ and $6 \%$ per year in 2007 and 2008, respectively. In the French AERES program, the commitment to reduce GHG emissions of member companies by $15 \%$ overall between 2003 and 2007 was surpassed and emissions were actually reduced by $25 \%$, or over $6 \%$ per year. The companies that comprised the Dutch Long-Term Agreements (LTAs) also surpassed the program goal of 20\% savings between 1989 and 2000, realizing actual savings of 22.3\% during that period. Evaluations found that between $30 \%$ and $40 \%$ of the savings was stimulated by the government program, while the rest was autonomous. The follow-on program - the LTA2s - had similar success, with industry improving energy efficiency by $23.2 \%$ between the base year of 1998 and 2008. The program in Denmark, while less ambitious than other agreement programs, reduced overall $\mathrm{CO}_{2}$ emissions by about $0.7 \%$ per year, surpassing the program goal of a $0.6 \%$ annual reduction in overall $\mathrm{CO}_{2}$ emissions. The industries participating in the UK Climate Change Agreements (CCAs) consistently exceeded their two-year incremental goals during the period 2001 to 2008.

The five agreement programs reviewed in this report represent very different approaches. Four of the five programs were established by the government in support of overall energy efficiency or GHG emissions reduction goals. The fifth, the AERES program in France, was an industry-driven program that was established with the motivation to proactively avoid government-imposed carbon taxes. The Dutch LTA programs also provided industry with the reassurance that if they participated in the agreements they would be not be subjected to additional regulatory requirements, including energy or $\mathrm{CO}_{2}$ taxes. Participants in both the Dutch LTAs and the UK CCAs were given special treatment regarding environmental requirements typically imposed on large industries. In the Netherlands, companies were given an expedited environmental permitting process while in the UK compliance with environmental permits was granted automatically if the CCA targets were met by a company.

Despite the programmatic differences, some key elements in most of the programs appear to have provided industry with the structure and support needed to accomplish, and often exceed, the programmatic energy-saving or emissions-reduction goals. 


\section{Company Commitments}

Whether voluntary, under the threat of taxes, or under a taxation scheme, all five of the programs reviewed required participating companies to make specific commitments in terms of their energy-saving or emissions reduction goals as well as activities that they would undertake during the program. These goals and commitments were outlined in signed agreements between the companies and/or their industrial associations and the government.

Companies participating in the programs in Ireland and Denmark committed to implement an energy management program following national energy management standards. Energy audits were required of the agreement companies in Ireland and Denmark and were provided free to participants in the Dutch LTA program. Special investigations evaluating the potential to implement specific energy efficiency measures were undertaken by companies in Ireland and Denmark. Energy action plans that outlined how companies planned to reach their targets were required in the agreement programs in The Netherlands and Denmark. All programs included specific reporting requirements for participating companies. These are discussed further below.

\section{Monitoring, Reporting, Verification}

MRV requirements differed by program. Participants in the Irish EAP are required to have their compliance with the energy management standard certified by a third party. The members of the AERES program committed to publish their current emissions on an annual basis, which was verified by an independent organization. AERES engaged another association to develop common quantification, reporting and verification guidelines for the members. In The Netherlands, participating companies were required to provide their energy savings plans, monitoring reports, and company-level energy efficiency index calculations to NOVEM where they were reviewed for accuracy and completeness. Since 2003, the energy management systems of companies participating in the agreements in Denmark had to be certified by a national accreditation agency and annual reports on companies' performance as well as reports on the special investigations were required to be submitted to the DEA. In the UK, company reports were verified through sample audits by an independent agency and the sector associations were required to ensure the accuracy of the data they collected documenting company progress towards the targets.

\section{Government Commitments}

Government programs providing support to the companies participating in the agreements were an essential element of the programs in Ireland, Netherlands, Denmark, and the UK. The French government did not establish any programs in support of AERES, but rather AERES itself provided support to the participants.

All five agreement programs had dedicated organizations that administered the programs and provided support to the companies in reaching their goals (e.g. SEI, AERES, SenterNovem, DEA, DEFRA and later DECC). In addition, in the UK, the Carbon Trust provided information and technical expertise to the companies. 


\section{Resources, Tools, and Information-Sharing}

Countries with strong industrial energy efficiency programs provide information on energy efficiency opportunities through a variety of technical information sources including energy efficiency databases, software tools, and industry- or technologyspecific energy efficiency reports (Galitsky et al., 2004).

In the LIEN program in Ireland, seminars and workshops are held to share information from experts and other specialists, to demonstrate tools and resources for implementing or improving energy efficiency, and to address specific issues such as plastics processing, energy markets, renewable energy for industry, and staff awareness campaigns. Ireland's Energy MAP provides an online tool along with other energy-management resources that provide advice on both the managerial and technical aspects of energy efficiency. For members of the EAP, SEI provides advice and support, financial assistance, Special Initiatives that are designed for specific areas and provides tailor-made training, mentoring and advice to companies that have made progress. Companies in the EAP or LIEN programs can participate in Special Working Group activities such as site visits, audits, and demonstration projects.

In The Netherlands, knowledge sharing is supported through networks that focus on energy-efficiency improvement in specific areas and that assist in preparation of roadmaps for sectors. The UK's Carbon Trust identifies carbon emissions reduction opportunities and provides resources and tools to assist in implementation of the opportunities.

\section{Energy Audits}

Energy auditing involves collecting data on all of the major energy-consuming processes and equipment in a plant as well as documenting specific technologies used in the production process and identifying opportunities for energy efficiency improvement throughout the plant, typically presented in a written report. Tools, informational materials, and other energy efficiency products are often furnished during the energy audit. In Ireland, energy audits, conducted by independent experts, are provided to the EAP members. These audits identify measures needed to reach compliance with the energy management standard and the costs are covered by SEI up to a set maximum. Free audits were provided to companies that participated in the LTA1s in The Netherlands. In Denmark, companies that participated in the agreements during the first agreement period were required to undertake energy audits.

\section{Financial Incentives}

Financial incentives to encourage investment in energy-efficient industrial equipment and processes are provided to participants in the agreement programs in Ireland, The Netherlands, Denmark, and the UK.

Programs in Ireland, The Netherlands, and the UK allow companies to deduct the investment costs of purchased eligible energy-saving equipment from their profits in the year of purchase. The allowable deduction is $100 \%$ in Ireland and the UK and originally 
$40 \%$, but later increase to $55 \%$, in The Netherlands. Qualifying equipment for the Dutch program is provided on an "Energy List" and the costs associated with obtaining advice for purchased equipment could also be included in the deduction. A similar list of about 5,000 qualifying products is provided for the participants in the Irish agreements.

The Netherlands also provided companies with the opportunity to more rapidly depreciate investments in environmentally-friendly machinery, reducing operating profits and tax payments. As with the deduction program described above, a list of qualifying equipment was provided and the costs associated with obtaining advice on the purchased machinery were also subject to accelerated depreciation.

In Denmark, the government provided subsidies for half of the costs of energy audits. Energy audits were provided free of charge to participating companies in The Netherlands LTAs.

The UK's Carbon Trust provides interest-free loans to small- and medium-sized enterprises and has a venture capital team that invests in early-stage carbon reduction technologies.

\section{Recommendations}

Based on the international experience documented in this report, it is recommended that companies in California's industrial sector be engaged in a program to provide them with support to meet the requirements of AB32, The Global Warming Solutions Act. As shown in this review, structured programs that engage industry, require members to evaluate their potential efficiency measures, plan how to meet efficiency or emissions reduction goals, and provide support in achieving the goals, can be quite effective at assisting companies to achieve energy efficiency levels beyond those that can be expected to be achieved autonomously.

Staff members of SenterNovem in The Netherlands conveyed that in their experience, companies provided arguments against such programs prior to their commencement. The companies stated that they already knew what they could achieve, they had already implemented all possible measures, or they would need to close due to the restrictiveness of the agreements. Now, after participating in the program for a number of years, the companies are "very enthusiastic" about the Dutch LTAs especially because no similar support-based programs are offered through the European Union Emissions Trading Scheme, which some of them participate in. The companies especially see the benefits of the knowledge-sharing platforms in the LTA program (Leupen and de Zwart, 2008).

Similar sentiments were voiced by industrial association members interviewed in the UK. When the program was initially announced, there was fear and uncertainty (Reeson, 2008). Companies "moaned" but are now generally satisfied because the CCAs have raised awareness of energy efficiency and have worked out "reasonably well" for the member companies (Boyd, 2008; Pocklington, 2008). The Food and Drink Federation 
noted that the "carrot and stick" approach was absolutely vital to the success of the CCAs (Reeson, 2008). A representative from the Chemicals Industries Association said that the CCAs have not imposed significant additional costs and that "we like the CCAs" (Sturgeon, 2008). The semiconductor association representative explained that when the program was first announced, "some people within the industry thought that the government's mission was to help them close their doors. They need to remain competitive. They simply don't care about emissions. It would be hard to compete with these additional taxes. So they were very interested in getting the rebate as part of the CCAs. Most people are happy to submit to targets - this was a big selling point of the Climate Change Levy. The government was seen as wanting to help companies to become more energy efficient." The semiconductor association representative went on to explain that companies have not closed because of the Climate Change Levy or the CCAs; rather, they have taken advantage of the best practice, benchmarking, and information-sharing programs that the association and Carbon Trust has offered to them (Boyd, 2008).

In California, the Scoping Plan developed by the California ARB and approved by its Board in December 2008 outlines the actions required to meet the 2020 GHG emissions limit set by $A B 32$ (CARB, 2008). For the industrial sector, it is expected that most emission reductions will be realized through the cap and trade mechanism. Even so, there are a few regulatory requirements for California industries including mandatory reporting of GHG emissions and a requirement to conduct energy audits.

California's mandatory Regulation for the Mandatory Reporting of Greenhouse Gas Emissions requires the reporting and verification of GHG emissions from specified GHG emissions sources for operators of all cement plants as well as operators of petroleum refineries, hydrogen plants, and other facilities that emit $25,000 \mathrm{tCO}_{2}$ or more annually and operators of electricity generating or cogeneration facilities that have a nameplate generating capacity greater than or equal to 1 megawatt (MW) and that emit 2,500 $\mathrm{tCO}_{2}$ or more annually (California Code of Regulations, 2007).

In addition, all major industrial facilities that emit more than $0.5 \mathrm{MtCO}_{2}$ eq. annually are required to conduct an Energy Efficiency and Co-Benefits Audit of combustion and other direct sources of GHG emissions, to identify potential reduction GHG, criteria pollutant, and toxic air contaminant reduction opportunities. This regulation, which is currently under development, would be implemented through a regulation adopted by ARB, which will be initiated in 2010 and will be in effect by 2012. The measure concerns 70 industrial facilities, including 6 major oil and gas facilities, 3 hydrogen plants, one minerals facility, 11 cement plants, 17 refineries, 27 power plants, and 5 cogeneration facilities (CARB, 2009b).

Both the mandatory reporting of GHG emissions and the mandatory energy audits provide California industries with key initial information needed to begin implementation of GHG emissions reduction measures. Understanding both the current level of emissions as well as where emissions are generated in the facility and the emissions reduction potential gives facility owners and operators a baseline from which 
to start taking action. Based on the information gathered in this report, it is clear that additional supporting measures are needed to assist industry in fully achieving - and sometimes even surpassing - emissions reduction requirements.

Examples of potential supporting measures include development of energy efficiency databases, software tools, and industry- or technology-specific energy efficiency reports as well as information-sharing platforms for industries to participate in peer-to-peer discussions of successful energy-efficiency or GHG mitigation options. On the national level, the US Environmental Protection Agency's Energy Star for Industry program, convenes "focus" industries for which they develop energy efficiency guidebooks and encourage information-sharing (US EPA, n.d.). The U.S. Department of Energy's Industrial Technologies Program has developed numerous energy-efficiency software and energy assessment tools that could be useful to California industries (US DOE, n.d.). An overview of over 30 types of industrial sector energy efficiency products, services and delivery mechanisms is provided in Galitsky et al., (2004).

Thus, in addition to the elements already required of California's industries, robust supporting programs to assist California's manufacturers to identify and implement energy-efficiency and GHG emissions mitigations technologies and measures could be designed to compliment $A B 32$ and increase the energy-efficiency and competitiveness of California's industries. 


\section{References}

Aalbers, R.F.T., H.L.F. de Groot, and H.R.J. Vollebergh, 2004. Effectiveness of Subsidizing Energy Saving Technologies: Evidence from Dutch Panel Data, 6th IAEE European Energy Conference on Modelling in Energy Economics and Policy.

AEA Energy \& Environment, 2009. Climate Change Agreements: Results of the Fourth Target Period Assessment. Harwell Didcot, Oxfordshire, UK: AEA Energy \& Environment.

Association des Entreprises pour la Reduction de l'Effet de Serre (AERES) (French Association of Companies for the Reduction of Greenhouse Gases), 2008. Rapport 2006 : Engagements Volontaires des Entreprises dans la Lutte contre l'Effet de Serre. Paris: AERES.

Association des Entreprises pour la Reduction de l'Effet de Serre (AERES) (French Association of Companies for the Reduction of Greenhouse Gases), 2009. 2003-2007: bilan des engagements pour la Lutte contre l'Effet de Serre. Paris : AERES.

Australian Department of Industry, Tourism and Resources (DITR), 2009. Information from the website: www.energyefficiencyopportunities.gov.au http://www.ret.gov.au/ENERGY/EFFICIENCY/EEO/Pages/default.aspx

Avest, E. ter, Gerrits, R. 2003. "Lifecycle Energy System Scan (LESS); More about LESS in Long Term Agreements," in Proceedings of the ACEEE 2003 Summer Study on Energy Efficiency in Industry. Washington, DC: American Council for an Energy Efficient Economy.

Barker, T., Ekins, P., and Foxon, T., 2007. "Macroeconomic effects of efficiency policies for energy-intensive industries: The Case of the UK Climate Change Agreements, 20002010," Energy Economics 29 (2007) 760-778.

Bjørner, T.B. and H.H. Jensen, 2000. Industrial Energy Demand and the Effect of Taxes, Agreements and Subsidies. Copenhagen: AKF Forlaget.

Bjørner, T.B. and Jensen, H. H., 2002. "Energy Taxes, Voluntary Agreements and Investment Subsidies - A Micro-Panel Analysis of the Effect on Danish Industrial Companies' Energy Demand," Resource and Energy Economics 24: 229-249.

Blok, K., H.L.F. de Groot, E.E.M. Luiten, and M.G. Rietbergen, 2004. The Effectiveness of Policy Instruments for Energy-Efficiency Improvements in Firms: The Dutch Experience. Dordrecht, The Netherlands: Kluwer Academic Publishers.

Bohringer and Frondel, 2006. "Assessing Voluntary Commitments in the German Cement Industry: The Importance of Baseline". Reality Check: The Nature and Performance of Voluntary Environmental Programs in the United States, Europe and Japan, Richard D. Morgenstern, William A. Pizer (Ed.) p.105 pages-117 pages. 
Boyd, D., 2008. Personal communication with Derek Boyd, National Microelectronics Institute.

California Air Resources Board (CARB), 2008. "California Climate Change Scoping Plan Appendices, Volume I: Supporting Documents and Measure Detail, Chapter 8-Industry Sector Overview and Emission Reduction Strategies", http://www.arb.ca.gov/cc/scopingplan/document/appendices volume1.pdf\#page=181

California Air Resources Board (CARB), 2009a. "Greenhouse Gas Inventory Data - 2000 to 2006", available at http://www.arb.ca.gov/cc/inventory/data/data.htm

California Air Resources Board (CARB), 2009b. "Energy Efficiency and Co-Benefits Audits Public Workshop", ARB Staff Presentation, December 15, 2009, http://www.arb.ca.gov/cc/energyaudits/energyaudits.htm

California Code of Regulations, 2007. Regulation for the Mandatory Reporting of Greenhouse Gas Emissions, Sections 95100-95133, Title 17, http://www.arb.ca.gov/regact/2007/ghg2007/frofinoal.pdf

California Energy Commission, 2009a. Electricity and Natural Gas Consumption by North American Industrial Classification Code. Sacramento, Calif.: California Energy Commission.

California Energy Commission, 2009b. Natural California Refining Industry Operating Reports. Sacramento, Calif.: California Energy Commission.

Canadian Industry Program for Energy Conservation (CIPEC), 2007 "Annual Report", March 2007 Canadian Industry Program for Energy Conservation, Office of Energy Efficiency, Natural Resources Canada

Carbon Trust, 2008. http://www.carbontrust.co.uk/default.ct

Carbon Trust, 2005. The Enhanced Capital Allowance Scheme: Products and Claims. http://www.eca.gov.uk/etl/claim/ and http://www.eca.gov.uk/etl/criteria/

Chidiak, M. 2002. "Lessons from the French Experience with Voluntary Agreements for Greenhouse Gas Reduction” Journal of Cleaner Production 10(2).

Commissie Benchmarking, 2002. Benchmarking Covenant: High Degree of Industrial Participation Interim Report as at February 2002.

http://www.benchmarking-energie.nl/pdf files/Benchmarking\%20Covenant\%20uka.doc

Commissie Benchmarking 2004. Rapportage Commissie Benchmarking over monitoringjaar 2004. 
http://www.benchmarking-energie.nl/pdf files/Def.Jaarrap2005\%201.doc

Commissie Benchmarking, 1999. Energy Efficiency Benchmarking Covenant. http://www.benchmarking-energie.nl/pdf files/covteng.pdf

Danish Economic Council (DEC). 1993. Danish Economy, May 1993. Copenhagen: DEC.

Danish Energy Agency (DEA). 2000. Green Taxes for Trade and Industry-Description and Evaluation. Copenhagen: DEA.

http://www.ens.dk/graphics/Publikationer/Energibesparelser UK/Green-tax-uk-rap.PDF

Danish Energy Authority (DEA). 2001. Voluntary Agreements on Energy Efficiency Danish Experiences. Copenhagen: DEA.

http://www.ens.dk/da-

DK/ForbrugOgBesparelser/IndsatsIVirksomheder/TilskudtilCO2afgift/Documents/volunt ary agreements\%20version1.pdf

Danish Energy Authority, (DEA) 2002. "Energy Management in Industry- Danish Experiences", Copenhagen: DEA.

http://193.88.185.141/Graphics/publikationer/energibesparelser_uk/EnergyEfficiency/E nergy management.pdf

Danish Energy Agency (DEA). 2005. Green Taxes for Trade and Industry - Danish Experiences. Copenhagen: DEA.

http://www.ens.dk/da-

DK/ForbrugOgBesparelser/IndsatsIVirksomheder/TilskudtilCO2afgift/Documents/Green taxes\%20danish\%20experiences.pdf

Danish Ministry of Energy (DME). 1990. Energy 2000: A Plan of Action for Sustainable Development. Copenhagen: DME.

Department of Communications, Energy and Natural Resources (DCENR), 2009a. Accelerated Capital Allowance (ACA). Dublin, Ireland, Department of Communications, Energy and Natural Resources.

http://www.dcenr.gov.ie/Energy/Energy+Efficiency+and+Affordability+Division/ACA+Sch eme.htm

Department of Communications, Energy and Natural Resources (DCENR), 2009b. Maximising Ireland's Energy Efficiency: The National Energy Efficiency Action Plan 20092020. Dublin, Ireland: Department of Communications, Energy and Natural Resources. http://www.dcenr.gov.ie/NR/rdonlyres/FC3D76AF-7FF1-483F-81CD-

52DCB0C73097/0/NEEAP full launch report.pdf

Department of Energy and Climate Change, 2009. Climate Change Agreements: Guidance Papers. London: DECC. 
http://www.decc.gov.uk/en/content/cms/what_we_do/change_energy/tackling_clima/c cas/ccas_guidance/ccas_guidance.aspx

Department of Environment and Heritage (DEH), 2009. "Greenhouse Challenge Plus : an Australian Government - industry partnership to reduce greenhouse gas emissions and improve energy efficiency", Greenhouse Challenge Plus launch, Australian Greenhouse Office, in the Department of the Environment and Heritage

Department of Environment and Heritage (DEH), 2009. Information from the website: http://www.environment.gov.au/archive/settlements/challenge/index.html

Department of Environment, Food, and Rural Affairs (DEFRA), 2004. Climate Change Agreements: The Climate Change Levy. London: DEFRA.

Department of Environment, Food, and Rural Affairs (DEFRA), 2005a. UK Emissions Trading Scheme. London: DEFRA.

Department of Environment, Food, and Rural Affairs (DEFRA), 2005b. News Release: Industry Beats CO2 Reduction Targets. 21 July 2005.

Department of Environment, Food, and Rural Affairs (DEFRA), 2006. Climate Change: The UK Programme. London: DEFRA.

http://www.defra.gov.uk/environment/climate/programme/

Department of Environment, Food, and Rural Affairs (DEFRA), 2007. Climate Change Agreements: Results of the Third Target Period Assessment.

http://www.decc.gov.uk/media/viewfile.ashx?filepath=what\%20we\%20do/global\%20cli mate\%20change\%20and\%20energy/tackling\%20climate\%20change/ccas/caa analysis/c ca-jul07.pdf\&filetype $=4$

Energy Efficiency and Conservation Authority (EECA), 2008. "The Energy Efficiency and Conservation Authority: Annual Report 2007/2008", http://www.eeca.govt.nz/sites/all/files/year-of-action-07-08.pdf

Energy Information Administration (EIA), 2009. Form EIA-906/920 Database: Monthly Utility and Nonutility Power Plant Data. Washington DC: EIA. www.eia.doe.gov/cneaf/electricity/page/eia906 920.html.

Ericsson, K., 2006. Evaluation of the Danish Voluntary Agreements on Energy Efficiency in Trade and Industry. Copenhagen, Denmark. http://www.ens.dk/daDK/ForbrugOgBesparelser/IndsatsIVirksomheder/TilskudtilCO2afgift/Documents/evaluat ion\%20of\%20the\%20danish\%20voluntary\%20agreements\%20april\%202006.pdf

ETSU, 1999. Industrial Sector Carbon Dioxide Emissions: Projections and Indications for the UK, 1990 - 2020. See discussion of this report in ETSU, AEA Technology, 2001. Climate Change Agreements - Sectoral Energy Efficiency Targets (version 2). 
Finansministeriet, et al., 1999. Evaluering af grønne afgifter og erhvervene. Schultz Forlag.

Food and Drink Federation, 2007. Reducing Carbon Emissions from UK Business: The Role of the Climate Change Levy and Agreements. Written Response to the Environmental Audit Committee. London: Food and Drink Federation.

Future Energy Solutions, AEA Technology, 2004. Climate Change Agreements - Results of the First Target Period Assessment. Version 1.2.

http://www.decc.gov.uk/media/viewfile.ashx?filepath=what\%20we\%20do/global\%20cli mate\%20change\%20and\%20energy/tackling\%20climate\%20change/ccas/caa_analysis/c ca-aug04.pdf\&filetype $=4$

Future Energy Solutions, AEA Technology, 2005. Climate Change Agreements - Results of the Second Target Period Assessment. Version 1.

http://www.decc.gov.uk/media/viewfile.ashx?filepath=what\%20we\%20do/global\%20cli mate\%20change\%20and\%20energy/tackling\%20climate\%20change/ccas/caa_analysis/c ca-jul05.pdf\&filetype $=4$

Galitsky, C., Price, L., and Worrell, E., 2004. Energy Efficiency Programs and Policies in the Industrial Sector in Industrialized Countries. Berkeley, CA: Lawrence Berkeley National Laboratory (LBNL-54068).

German Environment Ministry (BMU) "Agreement on Climate Protection between the Government of the Federal Republic of Germany and German Business" Information from the website: http://www.bmu.de/english/climate/doc/3313.php

Gerrits, R., 2008. Personal communication with Reinier Gerrits, SenterNovem, April 2008.

Gerrits, R. and Oudshoff, B., 2003. "Energy Efficiency through Long-Term Agreements: Broadening the Horizon in the New LTA Approach," Proceedings of the ACEEE 2003 Summer Study on Energy Efficiency in Industry. Washington, DC: American Council for an Energy Efficient Economy.

Gudbjerg, Erik. 2009. "EMS as a Policy Instrument for Energy Efficiency in Ireland, Sweden and Denmark," Proceedings of 2009 Conference of Energy Efficiency in Motor Driven Systems. Nantes, France. September 14-17.

http://www1.cetim.fr/eemods09/pages/programme/052-Gudbjerg-final.pdf

HM Revenue \& Customs, n.d. ECA - 100\% Enhanced Capital Allowances for EnergySaving Investments.

http://www.hmrc.gov.uk/capital allowances/eca guidance.htm\#claimingfya 
Hansen, M.D., 2001. "The Danish Experience with Efficiency Improvement in Industrial and Commercial Sectors," Workshop on Best Practices in Policies and Measures, 8-10 October 2001, Copenhagen.

House of Commons, Environmental Audit Committee, 2008. Reducing Carbon Emissions from UK Business: The Role of the Climate Change Levy and Agreements. London: House of Commons.

International Energy Agency. 1997. Voluntary Actions for Energy-Related $\mathrm{CO}_{2}$ Abatement. Paris: OECD/IEA.

International Energy Agency (IEA), 2009. Energy Balances of OECD Countries. Paris: IEA.

International Institute for Sustainable Development (IISD), 1994. Accelerated Depreciation of Environmental Investments in the Netherlands.

http://www.iisd.org/greenbud/acceler.htm

Johannsen, K.S., 2002. "Combining Voluntary Agreements and Taxes - An Evaluation of the Danish Agreement Scheme on Energy Efficiency In Industry," Journal of Cleaner Production 10: 129-141.

Johannsen K. and A. Larsen, 2000. Voluntary Agreements - Implementation and Efficiency. The Danish Country Study. Case Studies in the Sectors of Paper and Milk Condensing. Copenhagen: AKF Forlaget.

Kavelaars, M., 2008. Personal communication with Marco Kavelaars, SenterNovem.

Kerssemeeckers, M., 2002. The Dutch Long-Term Voluntary Agreements on Energy Efficiency Improvement in Industry. Utrecht, The Netherlands: Ecofys

Klok, J., 2002. Negotiating EU CO2/Energy Taxation: Political Economic Driving Forces and Barriers. AKF Forlaget.

http://www.akf.dk/udgivelser/2002/pdf/negotiatingEUCO2.pdf/

Korea Energy Management Corporation (KEMCO), 2007. Energy Programs in Korea. http://www.kemco.or.kr/up_load/file/a_2.pdf

Korevaar, E., J. Farla, K. Blok and K. Schulte Fischedick, 1997. "A Preliminary Analysis of the Dutch Voluntary Agreements on Energy Efficiency Improvement," The Energy Efficiency Challenge, Proceedings of the 1997 European Council for an Energy Efficient Economy Summer Study, Splinderuv Mlyn, Czech Republic, 9-14 June 1997.

Krarup S., and Millock K., 2006, "Evaluation of the Danish Agreements on Industrial Energy Efficiency", Reality Check: The Nature and Performance of Voluntary Environmental Programs in the United States, Europe and Japan, Richard D. Morgenstern, 
William A. Pizer (Ed.) pp. 86-104.

Krarup, S. and Ramesohl, S., 2002. "Voluntary agreements on energy efficiency in industry - not a golden key, but another contribution to improve climate policy mixes", Journal of Cleaner Production 10 (2002) 109-120

Krarup, S., Togeby, M., and Johannsen, K., 1997. De første aftaler om energieffektivisering - erfaringer fra 30 aftaler indgået $i$ 1996. Working paper. Copenhagen: AKF Forlaget.

Lawrence Berkeley National Laboratory (LBNL), forthcoming. California Energy Balance Update. Berkeley, CA: LBNL.

Leupen, T. and de Zwart, M., 2008. Personal communication with Theo Leupen and Michel de Zwart, SenterNovem.

McKane, A., Williams, R., Perry, W., and Li, T. 2007. "Setting the Standard for Industrial Energy Efficiency," Industrial Management Issues, Paper \#070. Proceedings of 2007 Conference of Energy Efficiency in Motor Driven Systems. Beijing, China. June 10-13. http://industrial-energy.lbl.gov/files/industrial-

energy/active/0/Energy\%20Management\%20Paper.pdf

Ministry of Economic Affairs (MEA), 2001. Long-Term Agreements on Energy Efficiency: Results of LTA1 to Year-End 2000. The Hague: Ministry of Economic Affairs. http://www.senternovem.nl/mmfiles/8EZ--

02\%2E01\%20LTA\%20results\%202000\%20part1 tcm24-198282.pdf,

http://www.senternovem.nl/mmfiles/8EZ--

02\%2E01\%20LTA\%20results\%202000\%20part2 tcm24-198283.pdf,

http://www.senternovem.nl/mmfiles/8EZ--

02\%2E01\%20LTA\%20results\%202000\%20part3 tcm24-198284.pdf

National Audit Office, 2007. The Climate Change Levy and Climate Change Agreements: A Review by the National Audit Office. London: NAO.

National Environmental Policy Plan (NEPP), 1989. To Choose or to Loose. Ministry of Housing, Spatial Planning and the Environment, the Netherlands.

National Microelectronics Institute (NMI), 2009. Energy Efficiency \& CO2 Emissions. http://www.nmi.org.uk/manufacturing/emissions-

monitoring?searched=climate+change+agreements\&highlight=ajaxSearch_highlight+aja xSearch_highlight1+ajaxSearch_highlight2+ajaxSearch_highlight3sdfsdfs

Nippon Keidanren, 2007. "Results of the Fiscal 2007 Follow-up to the Keidanren Voluntary Action Plan on the Environment (Summary) - Section on Global Warming Measures- Performance in Fiscal 2006" , November 14, 2007, Nippon Keidanren (Japan 
Business Federation)

NSW - SEDA/DEUS

http://www.environment.nsw.gov.au/sustainbus/sustainabilityadvantage.htm

Nuijen, W., 1998. "Long Term Agreements on Energy Efficiency in Industry," in Martin et al., (eds.) Industrial Energy Efficiency Policies: Understanding Success and Failure, Proceedings of a Workshop Organized by the International Network for Energy Demand Analysis in the Industrial Sector. Utrecht, The Netherlands, June 11-12, 1998. (LBNL42368). http://ies.lbl.gov/iespubs/42368.pdf

Nuijen, W., 2002. "Energy Auditing, Assessments, and Energy Plans in The Netherlands," Presentation at the Workshop on Voluntary Agreements for China's Industrial Sector: Integrating International Experiences into Designing a Pilot Program, February 25-27, 2002, http://ies.Ibl.gov/iespubs/energyaudits.pdf

Nuijen, W. and Booij, M., 2002. Experiences with Long-Term Agreements on Energy Efficiency and An Outlook to Policy for the Next 10 Years. Utrecht, The Netherlands: NOVEM.

http://www.senternovem.nl/mmfiles/Ita_experiences_report_tcm24-171835.pdf

Odyssee-MURE Project (OMP), 2008. Energy Efficiency Profile: Ireland 2008. OMP. Project. http://www.odyssee-indicators.org/publications/country profiles PDF/irl.pdf

Office of Energy, Government of Western Australia, n.d. Energy Smart Business. http://www.clean.energy.wa.gov.au/pages/energy smart business.asp

Organisation for Economic Co-operation and Development (OECD), 2009. "Exchange Rates", OECD. Stat Extracts, http://stats.oecd.org/index.aspx?queryid=169

Pender, M., 2004. UK Climate Change Agreements. Presentation at the Workshop on Industrial Tax and Fiscal Policies to Promote Energy Efficiency. 24 May 2005.

Pocklington, D., 2008. Personal communication with David Pocklington, British Cement Association.

Price, L., 2005. "Voluntary Agreements for Energy Efficiency or Greenhouse Gas Emissions Reduction in Industry: An Assessment of Programs Around the World," Proceedings of the 2005 ACEEE Summer Study on Energy Efficiency in Industry. Washington, DC: American Council for An Energy-Efficient Economy.

Price, L., Galitsky, C., Sinton, J., Worrell, E., Graus, W., 2005. Tax and Fiscal Policies for Promotion of Industrial Energy Efficiency: A Survey of International Experience. Berkeley, CA: Lawrence Berkeley National Laboratory. 
Price, L., Blok, K., Nuijen, W., and Pender, M., 2005. "Setting Voluntary Agreement Targets," presentation at the Workshop on Energy Efficiency Agreements, Beijing, November 15, 2005.

Reeson, S., 2008. Personal communication with Stephen Reeson of the Food and Drink Federation.

Rezessy, S., Bertoldi, P., Persson, A. 2005. "Are Voluntary Agreements an Effective Energy Policy Instrument? Insights and Experiences from Europe," Proceedings of the American Council for an Energy Efficient Economy's 2005 Summer Study on Energy Efficiency in Industry. Washington, DC: ACEEE.

Rietbergen, M., J. Farla, and K. Blok, 1998. "Quantitative Evaluation of Voluntary Agreements on Energy Efficiency," in Martin et al., (eds.) Industrial Energy Efficiency Policies: Understanding Success and Failure. Proceedings of a Workshop Organized by the International Network for Energy Demand Analysis in the Industrial Sector. Utrecht, The Netherlands, June 11-12, 1998 (LBNL-42368), http://ies.lbl.gov/iespubs/42368.pdf

Rietbergen, M., Farla, J., and Blok, K., 2002. "Do agreements enhance energy efficiency improvement? Analysing the actual outcome of long-term agreements on industrial energy efficiency improvement in The Netherlands" Journal of Cleaner Production 10 (2002) 153-163.

SenterNovem, 2001. Long-Term Agreements on Energy Efficiency: Results of LTA1 to Year-End 2000. The Hague: Ministry of Economic Affairs.

http://www.senternovem.nl/mmfiles/8EZ--

02\%2E01\%20LTA\%20results\%202000\%20part1 tcm24-198282.pdf,

http://www.senternovem.nl/mmfiles/8EZ--

02\%2E01\%20LTA\%20results\%202000\%20part2 tcm24-198283.pdf,

http://www.senternovem.nl/mmfiles/8EZ--

02\%2E01\%20LTA\%20results\%202000\%20part3 tcm24-198284.pdf

SenterNoven, 2004a. Structural Attention for Energy Efficiency by Energy Management. Sittard and Utrecth, The Netherlands: SenterNovem. http://www.senternovem.nl/mmfiles/3MJAF04.17\%20-

\%20Structural\%20attention\%20for\%20energy\%20efficiency\%20by\%20energy\%20manag ement\%20-\%20June\%202004 tcm24-122943.pdf

SenterNoven, 2004b. The Energy Management System Specification with Guidance for Use. Sittard and Utrecth, The Netherlands: SenterNovem. http://www.senternovem.nl/mmfiles/3MJAF04.16\%20\%20Energy\%20Management\%20System\%20Specification\%20with\%20Guidance\%20for\% 20Use\%20-\%20June\%202004 tcm24-122944.pdf

SenterNovem, 2004c. Energy Management Checklist. Sittard and Utrecht, The 
Netherlands: SenterNovem. http://www.senternovem.nl/mmfiles/3MJAF04\%2E15\%20\%20Energy\%20Management\%20Checklist\%20-\%20June\%202004 tcm24-122945.pdf

SenterNovem, 2005a. MIA and Vamil: Tax Relief for Investments in Environmental Friendly Machinery. http://www.senternovem.nl/vamil mia/English.asp

SenterNovem 2005b. EIA: Tax Relief for Investments in Energy-saving Equipment and Sustainable Energy.

http://www.senternovem.nl/eia/eia_energy_investment_allowance.asp

SenterNovem, 2005c. Long Term Agreements on Energy Efficiency in The Netherlands: Results for 2004. The Hague: Ministry of Economic Affairs. http://www.senternovem.nl/mmfiles/3MJAF05.03\%20LTA\%20Results\%20for\%202004 t cm24-175780.pdf

SenterNovem, 2006. Long Term Agreements on Energy Efficiency in The Netherlands: Results for 2005. The Hague: Ministry of Economic Affairs.

http://www.senternovem.nl/mmfiles/2MJAF0638 LTA Results for 2005 UK tcm24209539.pdf

SenterNovem, 2009. Long-Term Agreements on Energy Efficiency in the Netherlands: Results of 2008. The Hague: Ministry of Economic Affairs.

Shock, R., 2000. The UK Energy Efficiency Best Practice Programme. http://www.un.org/events/energy2000/speaker/shock/shock.ppt.

Statutory Instruments (S.I.), No. 399 of 2008, (2008). Taxes Consolidation Act 1997 (Accelerated Capital Allowances for Energy Efficient Equipment) Order 2008. Dublin, Ireland: the Stationery Office. http://www.attorneygeneral.ie/esi/2008/B26474.pdf

Statutory Instruments (S.I.), No. 393 of 2009, (2009). Taxes Consolidation Act 1997 (Accelerated Capital Allowances for Energy Efficient Equipment) (Amendment) (NO.2) Order 2009. Dublin, Ireland: the Stationery Office. http://www.dcenr.gov.ie/NR/rdonlyres/BF691FD8-CF1E-4685-BDC36D7F29ED2DBA/0/ACARegs2009SI393of2009.pdf

Sturgeon, N., 2008. Personal communication with Nick Sturgeon, Chemicals Industries Association.

Sustainable Energy Ireland (SEI), 2007. Energy Efficiency in Ireland: 2007 Report, Cork and Dublin, Ireland: Energy Policy Statistical Support Unit and SEI, http://www.sei.ie/Publications/Statistics Publications/EPSSU Publications/Energy Effici ency in Ireland_2009/EPSSU Energy Efficiency Report_2007Fnl.pdf

Sustainable Energy Ireland (SEI), 2009a. The Large Industry Energy Network 
http://www.sei.ie/Your Business/Large Industry Energy Network/

Sustainable Energy Ireland (SEI), 2009b. Energy Efficiency in Ireland: 2009 Report, Cork and Dublin, Ireland: Energy Policy Statistical Support Unit and SEI, http://www.sei.ie/Publications/Statistics Publications/EPSSU Publications/Energy Effici ency in Ireland 2009/Energy Efficiency Report 2009.pdf

Sustainable Energy Ireland (SEI), 2009c. Accelerated Capital Allowances. [Website]. http://www.sei.ie/Your Business/Accelerated Capital Allowance/

Sustainable Energy Ireland and Large Industrial Energy Network (SEI \& LIEN), 2007. Large Industrial Energy Network: Annual Report 2006. Dublin, Ireland: SEI and LIEN. http://www.sei.ie/uploadedfiles/Energyandbusiness/LIEN/SEI LIEN AR 2006 finalWEB. pdf

Sustainable Energy Ireland and Large Industrial Energy Network (SEI \& LIEN), 2008. Large Industrial Energy Network: Annual Report 2007. Dublin, Ireland: SEI and LIEN. http://www.sei.ie/Your Business/Large Industry Energy Network/LIEN Annual Report s/LIEN\%20Annual\%20Report\%202007.pdf

Sustainable Energy Ireland and Large Industrial Energy Network (SEI \& LIEN), 2009. Large Industrial Energy Network, Annual Report 2008. Dublin, Ireland: SEI and LIEN. http://www.sei.ie/Your Business/Large Industry Energy Network/LIEN Annual Report s/LIEN Annual Report 2008.pdf

Sustainability Victoria, n.d. Resource Smart Business.

http://www.seav.vic.gov.au/manufacturing/sustainable manufacturing/resources/6/SV Make it your business.pdf

Svendsen, Gert Tinggaard. 1997. "A General Model for CO2 Regulation: The Case of Denmark," Energy Policy, Vol. 26, No.1, pp.33-44.

Swedish Energy Agency (SEA), 2009, "Programme for improving energy efficiency in energy-intensive industries (PFE)", information from the website: http://www.energimyndigheten.se/en/Energy-efficiency/Companies-andbusinesses/Programme-for-improving-energy-efficiency-in-energy-intensive-industriesPFE/

Swedish Energy Agency (SEA), 2007. "Two years with PFE The first published results from the Swedish LTA programme for improving energy efficiency in industry" http://webbshop.cm.se/System/ViewResource.aspx?p=Energimyndigheten\&rl=default:/ Resources/Permanent/Storageltem/a20d33447b62463e8e1a5d662b733bbe/ET2007 16 .pdf

Togeby, M., Bjorner, T.B., and Johannsen, K., 1998. “Evaluation of the Danish CO2 Taxes 
and Agreements," in Martin et al., (eds.) Industrial Energy Efficiency Policies: Understanding Success and Failure: Proceedings of a Workshop Organized by the International Network for Energy Demand Analysis in the Industrial Sector. Utrecht, The Netherlands, June 11-12, 1998. (LBNL-42368).

Togeby, M., Johannsen, K., Ingrslev, C., Thingvad, K., and Madsen, J., 1999. "Evaluations of the Danish Agreement System," Proceedings of the 1999 American Council for an Energy-Efficient Economy Summer Study on Energy Efficiency in Industry. Washington, DC: ACEEE.

UK Department of Trade and Industry, 2003. Our Energy Future: Creating a Low Carbon Economy. www.berr.gov.uk/files/file10719.pdf

UK Steel, 2007. Annual Review 2007. London: EEF. http://www.eef.org.uk/NR/rdonlyres/C1F3095D-037F-4280-A2AB2EB9B71C04B9/13521/UKSteelAnnualReview2008.pdf

U.S. Department of Energy, n.d. Industrial Technologies Program. http://www1.eere.energy.gov/industry/

U.S. Energy Information Administration, 2009a. Fuel Oil and Kerosene Sales 2000. Washington, D.C.: DOE.

U.S. Energy Information Administration, 2009b. State Consumption Data. Washington, D.C.: DOE. www.eia.doe.gov/emeu/states/_use_multistate.html.

U.S. Energy Information Administration, 2009c. EIA-906/920 Database: Monthly Utility and Nonutility Power Plant Data.. Washington, D.C.: DOE. www.eia.doe.gov/cneaf/electricity/page/eia906_920.html.

U.S. Environmental Protection Agency (US EPA), n.d. Industries in Focus. http://www.energystar.gov/index.cfm?c=in_focus.bus_industries_focus

U.S. Geological Survey (USGS), 2009. Fuel and Electricity Consumption by California Cement Plants, 1991-2007, Washington, D.C.: U.S. Geological Survey.

Vermeeren, R., 2008. Personal communication with Ronald Vermeeran, SenterNovem, April 2008. 


\section{Acronyms}

AB32

ACA

AERES

ARB

AUS

BDI

Btus

CALEB

CAN

CARB

CCA

CCTA

$\mathrm{CH}_{4}$

$\mathrm{CHP}$

CIPEC

$\mathrm{CO}_{2}$

$\mathrm{CO}_{2}$-eq

DAIEE

DANAK

DEA

DECC

DEFRA

EAP

ECP

EECA

EEI

EEO

EIA

EMS

ESP

EU

EUR

GCP

GHG

GWh

HFC

HVAC

IEA

ISO

kWh

KEMCO

LBNL

LIEN
Assembly Bill 32 (California Global Warming Solutions Act)

Accelerated Capital Allowances

Association des Entreprises pour la Reduction de l'Effet de Serre

Air Resources Board

Australian

Bundesverband der deutschen Industrie

British thermal units

California Energy Balance

Canada

California Air Resources Board

Climate Change Agreement

Central Customs and Tax Administration

methane

combined heat and power

Canadian Industry Program for Energy Conservation

carbon dioxide

carbon dioxide equivalent

Denmark Agreement on Industrial Energy Efficiency

Danish Accreditation Scheme

Danish Energy Agency

Department of Energy and Climate Change

Department of Environment, Food, and Rural Affairs

Energy Agreements Programme

Energy Conservation Plan

Energy Efficiency and Conservation Authority

energy efficiency index

Energy Efficiency Opportunities

Energy Information Administration

energy management system

Energy Saving through Partnership

European Union

euro

Greenhouse Challenge Plus

Greenhouse gas

gigawatt hours

hydrofluorocarbon

heating, ventilation, and cooling

International Energy Agency

Industrial Standards Organization

kilowatt hour

Korea Energy Management Corporation

Lawrence Berkeley National Laboratory

Large Industry Energy Network 


\begin{tabular}{|c|c|}
\hline LTA & Long-Term Agreement \\
\hline LTP & Long-Term Plan \\
\hline MAP & Management Action Plan \\
\hline MWh & megawatt hour \\
\hline Mt & million metric tons \\
\hline $\mathrm{MtCO}_{2}$ & million metric tons carbon dioxide \\
\hline $\mathrm{MtCO}_{2} \mathrm{eq}$ & million metric tons carbon dioxide equivalent \\
\hline $\mathrm{N}_{2} \mathrm{O}$ & nitrous oxide \\
\hline NA & not available \\
\hline NASI & National Standards Authority of Ireland \\
\hline NEEAP & National Energy Efficiency Action Plan \\
\hline NEEP & National Environmental Policy Plan \\
\hline NMI & National Microelectronics Institute \\
\hline NO & nitric oxide \\
\hline NOVEM & Dutch Agency for Energy and Environment \\
\hline $\mathrm{NZ}$ & New Zealand \\
\hline OECD & Organization for Economic Cooperation and Development \\
\hline PFC & Perfluorocarbons \\
\hline PFE & $\begin{array}{l}\text { Program For Improving Energy Efficiency in Energy-Intensive } \\
\text { Industries }\end{array}$ \\
\hline PJ & petajoules \\
\hline SEI & Sustainable Energy Ireland \\
\hline SEK & Swedish krona \\
\hline $\mathrm{SF}_{6}$ & sulfur hexafluoride \\
\hline $\mathrm{SO}_{2}$ & sulfur dioxide \\
\hline TBtu & thousand British thermal units \\
\hline tCO2 & ton carbon dioxide \\
\hline TJ & terajoules \\
\hline TWh & terawatt hour \\
\hline UK & United Kingdom \\
\hline US & United States \\
\hline USD & United States dollars \\
\hline USDOE & United States Department of Energy \\
\hline USEPA & United States Environmental Protection Agency \\
\hline UTO & Useful Thermal Output \\
\hline VAMIL & Accelerated Depreciation on Environmental Investment \\
\hline WBCSD & World Business Council for Sustainable Development \\
\hline WRI & World Resources Institute \\
\hline
\end{tabular}




\title{
Appendix - Brief Descriptions of All Agreement Programs
}

\section{Completely Voluntary Programs}

\begin{abstract}
Australia
Australia has two Government programs that encourage businesses to improve their energy efficiency and reduce GHG emissions: the Energy Efficiency Opportunities (EEO) and the Greenhouse Challenge Plus (GCP) programs. In this section only the GCP program is described as it represents a completely voluntary program while the EEO program is described later in section 5.1.3.
\end{abstract}

The GCP was launched in 2005 and builds on the success of the Greenhouse Challenge program. The GCP is larger than the EEO program, with a greater number of members (750 in 2006) and a focus not only on energy efficiency but also on reporting and managing GHG emissions associated with company activities. It is a voluntary program with the exception of mandatory disclosure for companies claiming more than \$3 million (US \$2.5 million) ${ }^{14}$ under the Fuel Excise Rebate Scheme ${ }^{15}$ (around 8 million liters of offroad diesel or 16.4 million liters of on-road diesel, depending on prices).

The GCP involves undertaking an emissions inventory, preparing an action plan (including identification of cost-effective actions to reduce GHG emissions, performance indicators and forecast of expected emissions abated), preparing a public statement that include the planned actions, and agreeing to participate in independent verification. Each GHC Plus member is required to submit progress reports annually. In exchange, the Australian Greenhouse Office assists members in benchmarking their performance to best practice, provides online tools and guides and organizes workshops. Participants are able to network and learn from other participating businesses, and gain recognition for their reductions through the use of the Challenge plus logos and marketing material. The government provides assistance via industry advisors and online tools and guides.

The GCP program is still in an early stage and no assessment report has yet been published. It is projected to contribute approximately 15 million $\mathrm{MtCO}_{2}$ emissions reduction each year during 2008-2012 (DEH, 2009). In May 2004, the Australian Government strengthened its commitment to Challenge Plus - Enhanced Industry Partnerships action, providing an additional AUS\$31.6 million (US\$26.6 million). ${ }^{16}$ The cost to government until then was AUS\$24 million (US\$20.2 million) ${ }^{17}$ over four years.

\footnotetext{
${ }^{14} 2008$ exchange rate of 1.19 AUS \$per US\$ (OECD, 2009).

${ }^{15}$ The principal industry types covered by this requirement are the mining and transport industry sectors. This requirement has increased participants by approximately 70 companies.

${ }^{16} 2008$ exchange rate of 1.19 AUS \$per US\$ (OECD, 2009).

172008 exchange rate of 1.19 AUS \$per US\$ (OECD, 2009).
} 


\section{Canada}

The Canadian Industry Program for Energy Conservation (CIPEC) is a voluntary partnership between the Government of Canada and companies aimed at improving Canada's industrial energy efficiency. Members share information about best practices and identify common needs.

CIPEC include 5,000 companies representing more than $98 \%$ of all industrial energy use in Canada. However, only 1,400 industrial facilities have committed to energy-saving improvements with the CIPEC Leader Company Initiative. CIPEC recommends that CIPEC leaders develop an action plan and set energy-efficiency targets, but it is not a requirement. In return CIPEC leader companies are eligible for discounts on expenses linked to CIPEC activities, such as energy management workshops or access to experts.

In 2007, the government of Canada announced about CAN \$20 million (US\$ 18.7 million $)^{18}$ in funding over 4 years through the ecoENERGY for Industry Initiative to provide training and energy audits and to help industrial facilities overcome financial barriers to improving the energy efficiency of their operations. This is complemented by the ecoENERGY Retrofit program for small and medium scale enterprises, which provides funds to finance improvement in buildings and equipment. These initiatives are delivered through CIPEC.

The 2007 CIPEC Annual Report (CIPEC, 2007) presents the total combined energy intensity improvement of $10.5 \%$ between 1990 and 2005 as the results of its actions. This represents a $\mathrm{CO}_{2}$ emissions saving of $33.7 \mathrm{Mt}$ and an energy costs saving of CAN $\$ 3.9$ billion (US\$ 3.7 billion) in 2005 . However, it is difficult to know how much of these improvements are the sole result of CIPEC actions. It is likely that some of the intensity reduction would have occurred in the absence of CIPEC.

The CIPEC Annual Report also reports the following results for specific programs:

- "Dollars to \$ense" workshops have helped companies to save an estimated 9,270 terajoules (TJ), equivalent to $0.92 \mathrm{MtCO}_{2}$ emission between fall 1997 to end of March 2007

- Energy audits have allow to avoid $0.84 \mathrm{MtCO}_{2}$ emissions since 2001

${ }^{18} 2008$ exchange rate of 1.07 CAN \$ per US\$ (OECD, 2009). 


\section{Ireland}

There are two key voluntary energy efficiency programs in the industrial sector in Ireland operated by Sustainable Energy Ireland (SEI): the Large Industry Energy Network (LIEN) that provides a network of expertise and sets energy reduction targets, and the Energy Agreements Programme which requires that the new Irish Energy Management Standard IS393 be installed.

LIEN was established in 1995 and is a voluntary network initiative operated by SEI. Workshops and seminars are organized throughout the year for LIEN members, providing them with a forum to learn from energy experts and other specialists, as well as from other energy managers. The program is reserved for companies with an energy bill of more than $€ 1$ million (US $\$ 1.5$ million). ${ }^{19}$ Each member agrees to undertake an energy audit, develop a management program for energy use, set energy-saving targets to address energy waste and $\mathrm{CO}_{2}$ emissions at its facilities, and to report publicly progress towards these targets. Collectively, energy and emission savings are accounted for and contribute to the achievements of the National Energy Efficiency Action Plan (SEI, 2008).

In 2006, SEl launched the Energy Agreements Programme for companies interested in signing energy agreements aimed at reducing energy consumption. The Programme is primarily intended for large energy users and requires participating companies to sign an initial three-year agreement with SEI. The program's goal is to support annual $1 \%$ reductions in national energy consumption above business-as-usual from 2008 in line with the new European Union directive on end-use energy efficiency. Firms joining the scheme must progressively meet the requirements of Irish Energy Management Standard IS 393. IS 393 is a formalized energy management system, which follows a method similar to ISO14001 covering all aspects of a company's approach to managing its energy. In doing this, the company will attain the highest level of energy management which is independently certified and helps to produce savings. SEI offers support to any company that shows meaningful engagement and follows up on opportunities identified. As of June 2008, about 60 companies have signed an agreement with SEI (SEI \& LIEN, 2008).

SEI launched new support services for small businesses in 2007 and has already provided 1,000 firms with advice, training and mentoring.

The 2007 LIEN Annual Report (2008) shows that energy avoided due to energy-efficiency measures was equal to 1,753 gigawatt hours (GWh) in 2007, representing $6.9 \%$ of total energy use. On average, members achieved year-on-year energy savings of about $3 \%$. Since 1995, the program has resulted in savings of $30 \%$ of energy use according to the LIEN annual report.

${ }^{19} 2008$ exchange rate of $0.68 €$ per US\$ (OECD, 2009). 


\section{South Korea}

The Korea Energy Management Corporation (KEMCO) manages a voluntary agreement program between industries and the government in South Korea. The program is designed for companies that consume over 84 terajoules (TJ) ${ }^{20}$ annually. Companies that join the program need to prepare an energy efficiency improvement action plan and commit to achieve an energy-efficiency improvement target and a GHG emission reduction target. It is recommended but not compulsory that the energy-efficiency target be more than $5 \%$ energy savings for 5 years compared to the total amount of energy consumption in the year before the agreement. Every year, companies submit a progress report to KEMCO.

In exchange, companies can then take advantage of low-interest loans and tax incentives to promote energy conservation and GHG emissions reduction as well as technical support. As of 2007, a total of 1,353 companies participated in the agreement (KEMCO, 2007).

The voluntary agreement program is supplemented with the Energy Saving through Partnership (ESP) program. The ESP Council enables industrial companies to share new energy-saving technologies and information with each other. It organizes workshops and conferences to discuss best practices and provides the latest information on energyefficient technologies and practices. Only factories using more than $837 \mathrm{TJ}$ annually can participate in the ESP program, with the exception of factories in the automobile, food, electrical and electronics industries that use over $418 \mathrm{TJ}$ annually.

The companies that have joined the agreement have reduced their energy use 564 petajoules (PJ) from 1999 through 2006, representing savings of $43.2 \mathrm{MtCO}_{2}$.

The Ministry of Knowledge Economy and KEMCO are taking action to strengthen the target-setting process by introducing negotiated agreements where the government will have a reinforced role in setting the target. This will apply to the companies consuming $837 \mathrm{TJ}$ annually (438 companies). The new program will also provide more incentives for achieving the target and will have a penalty.

\footnotetext{
${ }^{20} 1 \mathrm{TJ}=0.948$ million British thermal units (Btus).
} 


\section{New Zealand}

New Zealand has ratified the Kyoto Protocol and is committed to assisting international efforts to reduce GHG emissions. To help achieve this objective, a carbon tax was initially planned to be introduced on 1 April 2007. To reduce the impact of the carbon tax on New Zealand firms, the government had entered into negotiations with firms. In exchange for a tax exemption, businesses would commit to moving towards world's best practice in emissions management. However, after the 2005 election, the minor parties supporting the government opposed the proposed tax, and it was abandoned in December 2005.

Currently, the program aimed at reducing energy use in the industry sector is a voluntary program called "Emprove", operated by the Energy Efficiency and Conservation Authority (EECA) since 2002. The program targets large energy users defined as companies that spend over $\$ 500,000$ (US $\$ 320,000)^{21}$ per annum on energy. The program encourages the implementation of an energy management system and provides grants to cover energy audits. It also provides services including account manager support, energy management diagnostics, and website information.

The Emprove program targets the top 300 energy-using firms in New Zealand. The program has provided support to firms to implement energy savings equaling to 1,600 gigawatt hours (GWh) since its start in 2002, with savings of $362 \mathrm{GWh}$ for 2007. Under this program, more than 210 energy audits have been undertaken with potential savings of NZ\$26 million (US \$17 million) identified (EECA, 2008). The cost to government has been NZ\$ 2.2 million (US \$1.4 million) (EECA, 2008).

\footnotetext{
${ }^{21} 2008$ exchange rate of 1.57 EUR€ per US\$ (OECD, 2009).
} 


\section{Programs with Threatened Regulations or Taxes}

\section{France}

The French Association of Companies for the Reduction of Greenhouse Gases (AERES) is a group of corporations that have voluntarily committed themselves to reduce their GHG emissions over the period $2003-2007$ by $15 \%$. The voluntary agreement with the government was initiated by industries to avoid introduction of a national carbon tax. AERES members include 29 corporations and 4 industry associations, representing 57\% of GHG emissions of the French industry (including the energy industry) and $20 \%$ of total 2003 GHG emissions in France. The commitments of AERES members applied to two periods (2003-2004 and 2005-2007) and varied across companies, depending on efforts already made in the past, technological potentials, and production forecasts. The participation of the French government was minor. It approved the general framework agreement signed by each member and appointed four observers and an expert to the AERES Technical Consultative Committee, which advises on the seriousness of the company's commitment proposals.

When commitments are not fulfilled, AERES members may use early action credits within the specified limits developed by AERES, exchange emissions credits within the framework of AERES internal market or use, for the 2005-2007 period, $\mathrm{CO}_{2}$ credits bought on the European market and returned to the French administration in addition to the credits initially distributed by the government. If the company did not fulfill its commitments in spite of using the means and tools described above, it would have to pay a penalty of EUR $€ 10 / \mathrm{tCO}_{2}$ eq (US $\$ 14.6$ ) ${ }^{22}$ (AERES, 2007).

The AERES commitment scope is wider than the scope of the European Directive on $\mathrm{CO}_{2}$ emissions credits, and therefore wider than the scope of the emissions credits in the National Allocation Plan, as it covers other sectors than those defined by the Annex 1 of the Directive, and the six GHGs of the Kyoto protocol.

In 2008, AERES published an assessment report that reviews the AERES program between 2002 and 2007, the end of the two commitment periods (AERES, 2008). AERES members reduced their GHG emissions by $25 \%$ compared to 1990 , which is better than their original commitment of a $15 \%$ reduction. However, results differ across sectors, with the chemical and aluminium industries showing the largest GHG reductions. Overall, 5 corporations from the cement, chemical, and glass industries did not reach the targets they had committed to at the beginning of the second period 2005-2007. These corporations have hence used emissions credits from early actions and/or bought credit emissions from AERES members that had met their targets.

\footnotetext{
${ }^{22} 2008$ exchange rate of 0.68 EUR€ per US\$ (OECD, 2009).
} 


\section{Germany}

Germany is one of the first countries that committed to reduce its national GHG emissions. As early as 1990, the German government had decided on a target of reducing $\mathrm{CO}_{2}$ emissions by $25 \%$ by the year 2005 based on 1987 levels. In order to achieve these reductions, the introduction of a tax on $\mathrm{CO}_{2}$ emissions was discussed. However, the federation of German Industry (Bundesverband der deutschen Industrie, or BDI) opposed it and instead signed a voluntary agreement on emission reduction with the government. In 1995, then revised in 1996, BDI signed the "Climate Change SelfCommitment" that aimed at reducing specific $\mathrm{CO}_{2}$ emissions and specific energy consumption by up to $20 \%$ between 1990 and 2005 .

The $\mathrm{CO}_{2}$ reduction target was attained by most industry sectors in 2000. A further update to the voluntary agreement on climate protection was then adopted in November 2000. It enlarges the commitment to reduce the specific emissions of all six Kyoto Protocol GHGs $\left(\mathrm{CO}_{2}, \mathrm{CH}_{4}, \mathrm{~N}_{2} \mathrm{O}, \mathrm{SF}_{6}, \mathrm{HFC}\right.$ and PFC) by a total of $35 \%$ by the year 2012 (1990 baseline), with $\mathrm{CO}_{2}$ emissions expected to achieve a specific reduction of $28 \%$ as compared to 1990 . This agreement today covers more than $70 \%$ of industrial energy consumption and $99 \%$ of public electricity generation.

The major cost factor for implementing the German scheme is the monitoring system which is administered by an independent third party, the Rhine-Westphalia Institute for Economic Research. The Federal Government, represented by the Federal Ministry of Economics and the Federal Ministry for the Environment, contributes $50 \%$ towards financing climate protection monitoring, while the other half is directly financed by German businesses. The new agreement contains the commitment to promote the development of combined heat and power (followed by obligations incumbent upon individual branches of industry).

By 2000, five years in advance of the target date, most of the commitments were already fulfilled. ${ }^{23}$ This success has raised doubt about the strength of the target set by the industry. Concerns were raised as to how much of the reductions achieved would have occurred without the voluntary agreement in a business-as-usual case. Bohringer and Frondel (2006) demonstrated that in the case of the cement industry most of the savings would have occurred without any agreement. One of the major criticisms of the German voluntary agreement is that the industry branches unilaterally set their targets without any negotiation with the government. The participating branch associations published their own declarations with branch-specific targets.

\footnotetext{
${ }^{23}$ Note that no national report on the evaluation of the program could be found in English.
} 


\section{Japan}

The Keidanren Voluntary Action Plan on the Environment was established by Japan Business Federation (or Keidanren) in June 1997, with the purpose of reducing $\mathrm{CO}_{2}$ emissions from the industrial and energy-converting sectors in 2010 to levels below those of 1990. It groups 35 industries, represented by 131 industry association organizations. The plan's participants are not limited to the fields of manufacturing and energy industries but also cover commercial and transport companies. Although it is a voluntary agreement, the plan is closely linked with the government planning, notably regarding its Kyoto commitment that compels industries to comply.

The Keidanren's Voluntary Action Plan commits one target for all industries but does not specify a voluntary target for each industry. Instead, each of the 35 industry groups selects its own target in consultation with individual companies that form each group. Every year, industry group targets and action plans are subject to an annual review process, the results of which are made public. Companies that participate in the plan submit data on their commitment performance to the industry group which then reports to the Keidanren at a more aggregate level. The Keidanren then publishes an annual report assessing the performance of each industry group against the overall Keidanren target.

The Keidanren Voluntary Action Plan on the Environment is seen as a key measure in the industrial and energy-converting sectors' efforts toward the achievement of Japanese government's Kyoto Protocol Target Achievement Plan. In the Kyoto Protocol, the Japanese government has committed to a total (all sectors included) GHG emission reduction goal of $6 \%$ for the 1st commitment period (2007-2012) compared to a 1990 baseline.

The Keidanren Voluntary Action Plan on the Environment has steadily produced results since its inception in 1997. The 35 industries that participated in fiscal year 2006 (April 2006 to March 2007) together emitted $504.58 \mathrm{MtCO}_{2}$, compared to $512.03 \mathrm{MtCO}_{2}$ in fiscal year 1990, representing a total decrease of $1.5 \%$. The Keidanren agreement original target of $0 \%$ increase over 1990 has been achieved for the seventh consecutive year. The evaluation study forecasts that average $\mathrm{CO}_{2}$ emissions will be $2.9 \%$ below the fiscal 1990 level.

In the Fiscal 2007 Follow-up, the Japan Business Federation called for the active examination of upwardly revising industry targets based on the probability of achieving current targets. As a result, 17 industry groups in the industrial and energy-conversion sectors increased their target levels. 


\section{Voluntary Agreements Within Energy or GHG Tax Programs or With Strict Regulations}

\section{Australia}

As mentioned in the first section, Australia has two Government programs that encourage businesses to improve their energy efficiency and reduce GHG emissions: the Energy Efficiency Opportunities (EEO) and the Greenhouse Challenge Plus (GCP) programs. Here we describe the EEO program as it represents a program with strict regulation, while the GCP program is described in the first section as it is a completely voluntary program.

EEO is a mandatory program for corporations that use more than $0.5 \mathrm{PJ}$ of energy each year. This includes about 250 corporations which together are responsible for more than $60 \%$ of the total amount of energy used by businesses, and around $45 \%$ of all energy used in Australia.

Under the program, each corporation is required to undertake a detailed energy assessment where opportunities to improve energy use are indentified, and to report it publicly. EEO came into effect on July 2006. Corporations that met the thresholds submitted their assessment report by July 2008, and these are available to the public on the EEO website. Every year, progress reports will be required and also available to the public (DITR, 2009). However, implementation of energy efficiency opportunities is voluntary, meaning that corporations are free to make decisions on energy efficiency investments through their normal business processes.

EEO program is still in early stage and no assessment report has been yet published. 


\section{Denmark}

Similar to Germany, the Danish government took action early to reduce GHG emissions, setting its first national target in 1990 which called for the reduction of $\mathrm{CO}_{2}$ emissions by $20 \%$ by the year 2005 based on 1988 levels. In 1993, the Danish Government introduced a $\mathrm{CO}_{2}$ tax on industrial enterprises of $€ 13.3 / \mathrm{tCO}_{2}$ eq (US $\$ 19.5 / \mathrm{t} \mathrm{tCO} \mathrm{C}_{2}$ eq). ${ }^{24}$ In 1995 , the Danish Parliament adopted a Green Tax Package which also included sulfur dioxide $\left(\mathrm{SO}_{2}\right)$ taxes, as well as energy-efficiency subsidies financed from recycled revenue from the taxes. However, due to concerns over international competitiveness, the government granted industrial companies a large tax reduction if they agreed to implement specified energy reduction measures. While no binding targets were required, companies needed to carry out energy audits and establish an action plan in collaboration with the Danish Energy Authority (DEA). All measures with a payback period under 4 years were required to be implemented. The energy audits must be carried out by an independent auditor certified by the DEA and were paid for by the firm, which could apply for a subsidy covering $50 \%$ of the cost. If a company failed to follow through with its agreement, it had to repay the tax rebate. Collective agreements, covering several firms in the same sector, were signed to reduce administrative cost in some sectors. However, each company still had to sign an individual agreement within the industry association.

The first agreement period was 3 years (1996-1999) and companies had to report annually to the DEA. Two successive agreements were put in place (2000 to 2002 and 2003 onward). In order to reduce administrative costs, the energy audit is no longer compulsory and companies have to establish their action plan to reduce energy and $\mathrm{CO}_{2}$ emissions based on their own energy management system. The DEA no longer follows up on the firm's self report and monitoring to the independent third party. Since 2003, the energy management system has to be certified by DANAK, the Danish Accreditation Scheme (Krarup and Millock, 2006). Since the initiation of the European Union (EU) emissions trading scheme, companies that are covered by the quotas are fully reimbursed for their $\mathrm{CO}_{2}$ tax and have therefore dropped out of their voluntary agreement (Krarup and Millock, 2006).

Krarup and Ramesohl (2002) estimated that the administrative costs in the first phase amounted to $€ 17,000$ to $€ 33,000$ (US $\$ 25,000$ to US $\$ 48,000$ ) on average for each firm, including the energy audit and verification. The total administrative cost for the government, including monitoring, was estimated to be $€ 4$ million per year (US $\$ 5.9$ million). However, after 2000, considerable reductions in cost were made. Analyses of the net effects of these agreements (e.g. savings only due to the agreement and not including savings occurring in a business-as-usual scenario) found reductions of $2.6 \%$ in the period 1996 to 1999 and 1.9\% in the period 2000-2003 (Krarup and Millock, 2006). It was found that the agreement generally forced firms to implement investment projects with a payback period that would have not been considered business-as-usual.

\footnotetext{
${ }^{24} 2008$ exchange rate of 0.68 EUR€ per US\$ (OECD, 2009).
} 


\section{Sweden}

In 2004, a tax of SEK 0.005 per kilowatt hour (kWh) $(0.08 \text { cent } / \mathrm{kWh})^{25}$ on electricity use was introduced in the industry sector in Sweden, excluding manufacturing processes in the following sectors: metallurgy, electrolysis, chemical reduction (SEA, 2009). The tax was complemented by the Program For Improving Energy Efficiency in Energy-Intensive Industries (PFE) which grants tax exemptions to energy-intensive companies that take action to improve their energy efficiency. PFE is a long term agreement between the Swedish government and the energy-intensive industry. Similar to the Danish program, no specific target is required. Instead companies need to introduce an energy management system in accordance with the standard introduced in Sweden in 2003. The standard sets out a number of points the company must follow to obtain certification, including:

- Carrying out an energy audit and analyzing energy use within the company,

- Reviewing purchasing and changing its procedures if necessary to improve the efficiency of energy use, and

- Reviewing project planning procedures, and changing them if necessary to improve energy efficiency.

The PFE also requires that companies establish a list of measures to improve electricity efficiency and reported it in detail to the Swedish Energy Agency during the first two years of the program. The list must include all measures that have a payback time of less than three years. Over a five year cycle, companies must apply all the energy-efficiency improvement measures that have been identified, and which have a payback time of less than three years.

The PFE program is restricted to energy-intensive industries as defined as meeting the following criteria:

a) its energy products expenditure amounts to at least $3 \%$ of its production value;

b) the total energy and $\mathrm{CO}_{2}$ tax for the company amounts to at least $0.5 \%$ of its added value.

The latest assessment report available was published in 2007 (SEA, 2007). It assesses the first two years of the program. About 117 industrial companies had joined the PFE program by the end of 2006, which used about 30 terawatt hours (TWh) of electricity, or about one fifth of Sweden's total electricity use. Among the participants, the pulp and paper industry, sawmills, chemicals, foodstuffs, steel, and mining industries are the most represented on the program. The report explains that the first 98 action plans received by the Swedish Energy Agency represent a potential energy efficiency improvement of at least 1 TWh of electricity per year, for a total investment cost of over SEK 1000 million (US \$152 million).

${ }^{25} 2008$ exchange rate of 6.59 SEK per US\$ (OECD, 2009). 


\section{Switzerland}

In Switzerland, voluntary agreements were first introduced in 2002 by companies in the trade, industry and services sectors wishing to avoid the implementation of a carbon tax. However, in 2008, realizing that the mid-term federal objective of reducing GHG emissions by $6 \%$ from 1990 level, in 2006 was not reached, the government introduced a carbon tax as stated in the SwissEnergy action plan. The overall objective is to reduce $\mathrm{CO}_{2}$ emissions by $10 \%$ by 2010 compared to the 1990 level. The law provides that companies can be exempted from the tax if they undertake a voluntary agreement with the federal government to restrict their $\mathrm{CO}_{2}$ emissions to a certain level and subsequently meet their declared target. By the end of 2007, about 1,800 companies had signed an agreement, representing $40 \%$ of $\mathrm{CO}_{2}$ emissions of Switzerland's industry sector (3.8 Mt of $\mathrm{CO}_{2}$ ).

SwissEnergy's partner agency, the Energy Agency for Industry, is responsible for preparing and concluding target agreements. Different methods are used to establish targets, depending on the company's size and activity. For large-scale consumers from the industry and services sectors, groups of 8 to 15 companies are formed to jointly search for ways to increase energy efficiency. With the help of experts from the Energy Agency for Industry, energy-efficiency potentials are assessed which are used for defining the $\mathrm{CO}_{2}$ emissions targets for 2010. For small and medium-sized companies, groups of 30 to 50 or more are formed, and a simplified method is applied for defining $\mathrm{CO}_{2}$ targets on the basis of a benchmark. Targets are set in negotiation with the Energy Agency for Industry, based on each company's economic energy-efficiency potential and the overall federal target. The authority, with help of independent experts, examines the target and agrees to exempt the company from the $\mathrm{CO}_{2}$ tax if progress toward the target is met annually.

Every year, the Swiss Confederation allocates emissions allowances to individual companies who have agreed with the federal authorities on a legally-binding emissions reduction target. Each company which has been exempted from the $\mathrm{CO}_{2}$ tax by an official decision receives emission allowances corresponding exactly to its reduction target. If the company cuts its $\mathrm{CO}_{2}$ emissions below this target, it can sell the surplus allowances. If it emits $\mathrm{CO}_{2}$ in excess of its target, it can buy allowances from other companies.

The Energy Agency for Industry also offers a variety of instruments (e.g. energy management courses) for analyzing efficiency potentials and implementing suitable measures. In 2006, the Energy Agency for Industry received approximately 2 million

Swiss francs (US $\$ 2.17$ million) ${ }^{26}$ from the SwissEnergy program as financial support. Overall, the agency's fund amounted to more than 15 million Swiss francs (US \$16.26 million).

\footnotetext{
${ }^{26} 2008$ exchange rate of 1.084 Swiss francs per US\$ (OECD, 2009).
} 